Thiago Quintella Castro

Indicadores e métricas de desempenho para Centros de Difusão de Ciência, Educação e Cultura sustentáveis

\begin{abstract}
Dissertação de Mestrado
Dissertação apresentada como requisito parcial para obtenção do título de Mestre pelo Programa de PósGraduação em Metrologia (Área de concentração: Metrologia para Qualidade e Inovação) da PUC-Rio.
\end{abstract}

Orientadora: Prof $^{\mathrm{a}}$ Maria Fatima Ludovico de Almeida 


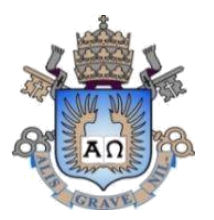

Thiago Quintella Castro

\title{
Indicadores e métricas de desempenho para Centros de Difusão de Ciência, Educação e Cultura sustentáveis
}

\author{
Dissertação apresentada como requisito parcial para \\ obtenção do título de Mestre pelo Programa de Pós- \\ Graduação em Metrologia (Área de concentração: \\ Metrologia para Qualidade e Inovação) da PUC-Rio. \\ Aprovada pela Comissão Examinadora abaixo \\ assinada. \\ Prof.- Maria Fatima Ludovico de Almeida \\ Orientadora \\ Programa de Pós-Graduação em Metrologia - PUC-Rio \\ Prof. Carlos Augusto Caldas de Moraes \\ Programa de Mestrado em Economia Empresarial - UCAM \\ Prof.- Maria Ângela Campelo de Melo \\ Departamento de Administração e Gestão (IAG) - PUC-Rio
}

Prof. Marcio da Silveira Carvalho

Coordenador Setorial do Centro

Técnico Científico - PUC-Rio

Rio de Janeiro, 25 de abril de 2016 
Todos os direitos reservados. É proibida a reprodução total ou parcial do trabalho sem autorização da universidade, do autor e de sua orientadora.

\section{Thiago Quintella Castro}

Bacharel em Administração pela Pontifícia Universidade Católica do Rio de Janeiro. Com mais de seis anos de experiência em planejamento estratégico e gestão na Fundação Planetário da Cidade do Rio de Janeiro, atua como consultor de negócios.

Ficha Catalográfica

Castro, Thiago Quintella

Indicadores e métricas de desempenho para Centros de Difusão de Ciência, Educação e Cultura sustentáveis / Thiago Quintella Castro ; orientadora: Maria Fatima Ludovico de Almeida. - 2016.

95 f.: il. (color.); $30 \mathrm{~cm}$

Dissertação (mestrado)-Pontifícia Universidade Católica do Rio de Janeiro, Centro Técnico Científico, Programa de Pós-Graduação em Metrologia para a Qualidade e Inovação, 2016.

Inclui bibliografia.

1. Metrologia - Teses. 2. Gestão sustentável. 3. Centros de Difusão de Ciência, Educação e Cultura. 4. Indicadores e métricas. 5. BSC sustentável. 6. FPCRJ. I. Almeida, Maria Fatima Ludovico de. II. Pontifícia Universidade Católica do Rio de Janeiro. Centro Técnico Científico. Programa de PósGraduação em Metrologia para a Qualidade e Inovação. III. Título.

CDD: 389.1 


\section{Agradecimentos}

À minha família, em especial à minha mãe, Lisiane Quintella, ao meu avô materno Derly Quintella, à minha avó de coração, Antonina Jansen, ao meu irmão de coração Leal Filho e à minha mãe de coração Graça Leal, pelo apoio incondicional e amor dedicado ao longo desses anos.

Aos meus amigos, em especial Andréa Nogueira, Liana Reis, Luís Cláudio Borges, Caciano Camilo, Rafael Franca (in memoriam) e Rosilan Piorski por serem a família que escolhi e por todo incentivo à realização de todos os meus objetivos e metas.

Aos novos amigos que fiz na minha trajetória pessoal, que sempre se fizeram presentes, e neste momento, em especial, à Irlaine, Juliana, Ulisses e Caciano, que no decorrer deste trabalho tanto me ouviram e fizeram de tudo o necessário para que se concretizasse.

À minha comadre Bruna e ao compadre Edson, que nunca mediram esforços para que quaisquer desafios fossem superados.

À minha orientadora, Professora Fátima Ludovico pelo apoio e contribuição valiosíssima, neste trabalho e em tantas outras iniciativas profissionais que compartilhamos.

Ao meu amigo Celso Cunha pela paciência dedicada e pelas horas a fio de aconselhamento, que tanto me fizeram crescer.

Aos meus colegas de trabalho na FPCRJ, que muito contribuíram com o desenvolvimento desta pesquisa.

À CAPES pelo apoio financeiro, sem o qual eu não poderia ter realizado este projeto.

A todos, que diretamente ou indiretamente estiveram envolvidos neste trabalho. 


\section{Resumo}

Castro, Thiago Quintella; Almeida, Maria Fatima Ludovico de (Orientadora).

Indicadores e métricas de desempenho para Centros de Difusão de Ciência, Educação e Cultura sustentáveis. Rio de Janeiro, 2016. 95 p. Dissertação de Mestrado - Programa de Pós-Graduação em Metrologia. Área de concentração: Metrologia para Qualidade e Inovação, Pontifícia Universidade Católica do Rio de Janeiro.

O objetivo da dissertação é propor um conjunto de indicadores e métricas de desempenho em sustentabilidade para Centros de Difusão de Ciência, Educação e Cultura (CDCEC), tomando-se como espaço de aplicação a Fundação Planetário da Cidade do Rio de Janeiro (FPCRJ). Esses indicadores e métricas integram um modelo de monitoramento e avaliação (MA) de desempenho sustentável, desenhado especialmente para CDCEC. O modelo combina a metodologia consagrada de Balanced Scorecard (BSC) com a abordagem de avaliação de sustentabilidade corporativa, disseminada pela Global Reporting Initiative (GRI), por meio de suas diretrizes para elaboração de relatórios de sustentabilidade. Nessa perspectiva, considerou-se de alta relevância um novo olhar sobre os modelos de gestão dos CDCEC e, em particular, o da Fundação Planetário da Cidade do Rio de Janeiro, levando-se em consideração o espaço que os serviços culturais e de ensino ocupam no setor de serviços e na economia como um todo. Ressalta-se que até o momento a GRI não divulgou um conjunto de diretrizes setoriais orientadas para CDCEC e organizações congêneres, abrindo-se, portanto, uma oportunidade de contribuição acadêmica para o aperfeiçoamento de seus suplementos setoriais. A pesquisa pode ser considerada descritiva e aplicada. Quanto aos meios de investigação, a metodologia compreende pesquisa bibliográfica e documental; análise de experiências internacionais de CDCEC e de referenciais normativos de avaliação da sustentabilidade aplicáveis a CDCEC; desenvolvimento de um modelo de monitoramento e avaliação (MA) de desempenho em sustentabilidade de CDCEC; aplicação do modelo de MA na FPCRJ, mediante um estudo de caso; discussão dos resultados do estudo de caso; e formulação das conclusões e recomendações. Destacam-se como resultados principais um conjunto de indicadores e métricas de desempenho em sustentabilidade para CDCEC, que integram um modelo de monitoramento e avaliação de gestão sustentável, desenvolvido especialmente para essas organizações.

\section{Palavras-chave}

Metrologia; gestão sustentável; Centros de Difusão de Ciência, Educação e Cultura; indicadores e métricas; BSC sustentável; FPCRJ. 


\section{Abstract}

Castro, Thiago Quintella; Almeida, Maria Fatima Ludovico de (Advisor).

Indicators and metrics for sustainable Centers for Diffusion of Science, Education and Culture. Rio de Janeiro, 2016. 95 p. MSc. Dissertation Programa de Pós -Graduação em Metrologia. Área de concentração: Metrologia para Qualidade e Inovação, Pontifícia Universidade Católica do Rio de Janeiro.

The objective of this dissertation is to propose a set of indicators and metrics for assessing the sustainability performance of Centers for Diffusion of Science, Education and Culture (CDSEC), whose applicability was demonstrated through a case study at the Fundação Planetário da Cidade do Rio de Janeiro (FPCRJ). These indicators and metrics, in turn, integrate a monitoring and evaluation (ME) model that combines the methodology of Balanced Scorecard (BSC) with the Sustainability Reporting Guidelines established by the Global Reporting Initiative (GRI). Within the context in which the research is situated, it is assumed that this effort will contribute to a broader understanding of sustainability assessment tools in CDSEC, emphasizing economic, social, and environmental sustainability issues. It is important to mention that until the present moment, the Global Reporting Initiative did not released a set of sectorial Sustainability Reporting Guidelines, especially addressed to CDSEC, as already occurs to other sectors. This opened a window of opportunity for academic research aiming at improving the GRI sectoral guidelines. This research can be considered applied and descriptive. The methodology encompasses literature review and documentary research; analysis of international experiences of CDSEC and selected normative references for assessing the sustainability of CDSEC; design of a monitoring and evaluation (ME) model for assessing sustainability performance of CDSEC; a case study carried out at the FPCRJ; discussion of the case study results; and formulation of conclusions and recommendations. The main result of this research is an innovative monitoring and evaluation (ME) model, especially designed for assessing the performance of CDSEC, from the perspective of corporate sustainability.

\section{Keywords}

Metrology; sustainable management; Centers for Diffusion of Science, Education and Culture; indicators and metrics; Sustainable BSC; FPCRJ. 


\section{Sumário}

1. Introdução

1.1. Definição do problema de pesquisa ..............................................................13

1.2. Objetivos: geral e específicos ....................................................................... 14

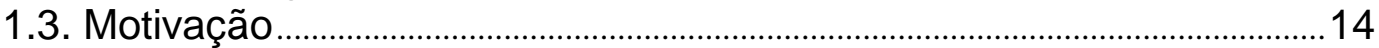

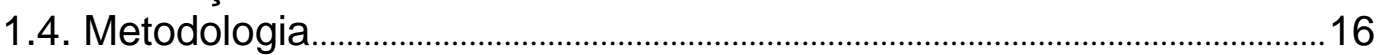

1.4.1 Fase exploratória e descritiva .......................................................................17

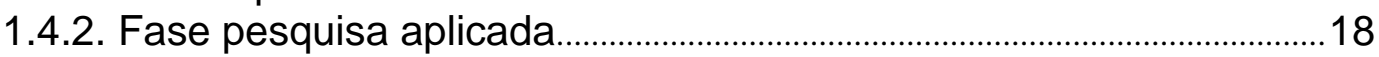

1.4.3. Fase conclusiva ............................................................................................. 18

1.6. Estrutura da dissertação ......................................................................................18

2. Centros de difusão de ciência, educação e cultura na perspectiva da sustentabilidade .......................................................................20

2.1. Responsabilidade social ....................................................................................2.

2.2 Balanced scorecard na perspectiva da sustentabilidade ...........................24

2.3. Um novo olhar sobre o modelo de gestão dos CDCEC ............................27

2.4. Experiências internacionais de CDCEC sustentáveis ..........................................29

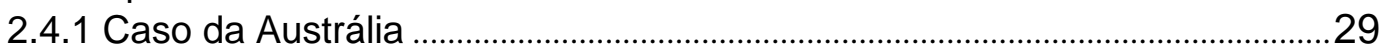

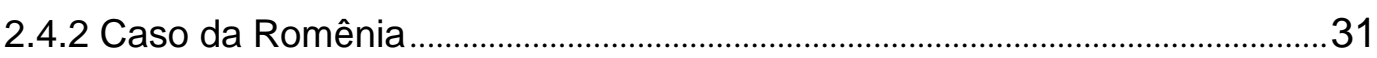

2.4.3 Caso da Canadá ..........................................................................................................32

2.5. Considerações finais sobre o capítulo ..........................................................33

3. Referenciais normativos de sustentabilidade aplicáveis a

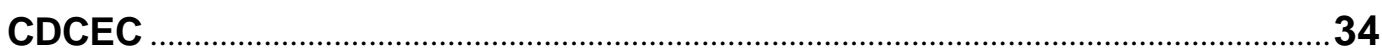

3.1. Global Reporting Initiative ...............................................................................34

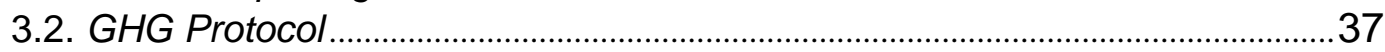

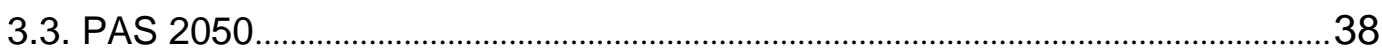

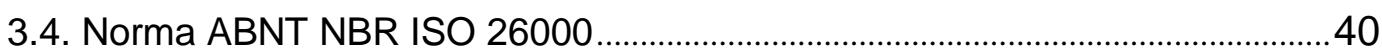

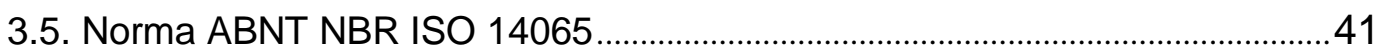

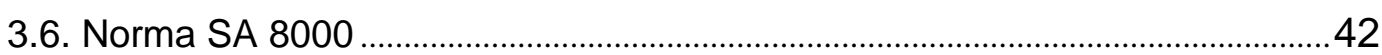

3.7. Carbon Disclosure Project.........................................................................................4

3.8. Quadro comparativo das normas e guias sobre gestão sustentável das organizações .....................................................................................4

3.9. Implicações para avaliação do desempenho sustentável de CDCEC ............46

4. Quadro lógico para construção de indicadores e métricas de desempenho para CDCEC sustentável .................................................................48

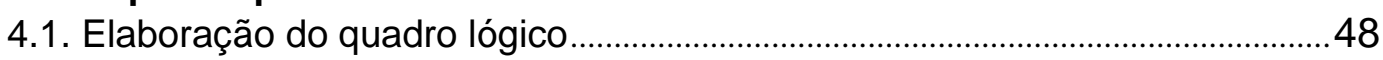

4.2. Conceituação e função básica dos indicadores ...................................................50

4.3. Construção de indicadores .................................................................................52

4.4. Implicações para construção de indicadores e métricas de desempenho para CDCEC sustentável 
5. Indicadores e métricas de desempenho para CDCEC sustentável:

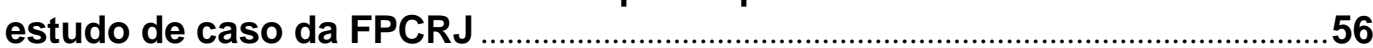

5.1.Questões e proposições do caso .............................................................................56

5.2. Tipo de caso: por que estudo de caso único holístico? ........................................57

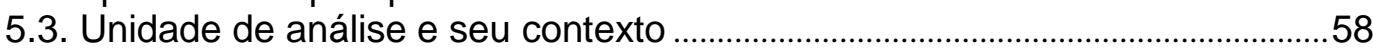

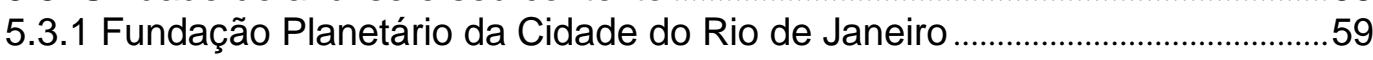

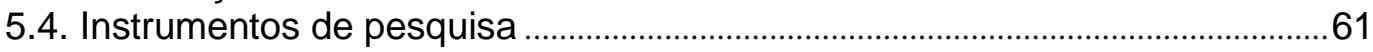

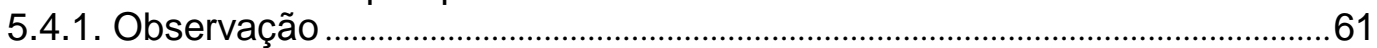

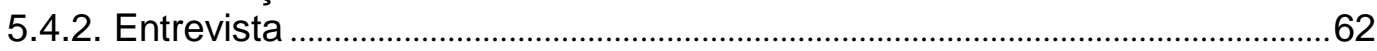

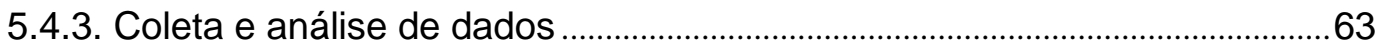

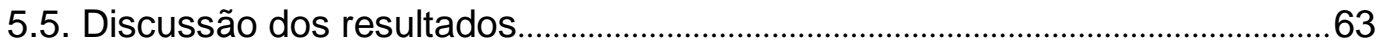

5.5.1. Aplicação do modelo de gestão sustentável de CDCEC na FPCRJ

5.5.2. Planejamento estratégico da FPCRJ 2013-2022: um processo participativo e balanceado em torno dos três pilares da sustentabilidade 66 5.5.3. Monitoramento e avaliação do desempenho sustentável da FPCRJ: integração do BSC sustentável com as diretrizes da GRI......................................69

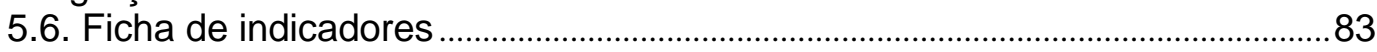

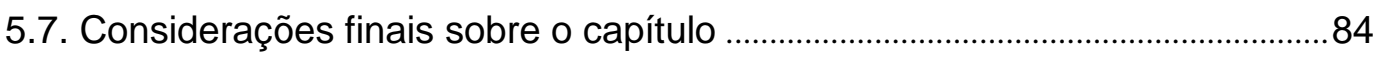

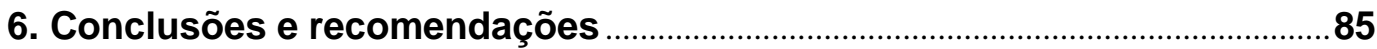

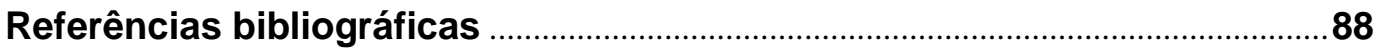

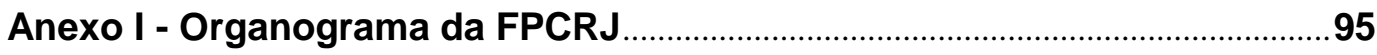




\section{Lista de Figuras}

Figura 1.1 - Desenho da pesquisa e seus componentes e métodos ........ 16

Figura 1.2 - Mapa conceitual da pesquisa ...................................................... 17

Figura 2.1 - Origens, características e expansão do movimiento ambientalista.............................................................................. 22

Figura 3.1 - Estrutura para aplicação da ISO 14065 com a norma ISO 14064-1, ISO 14064-2, ISO 14064-3 e ISO 14066 ................... 42

Figura 5.1 - Seleção do tipo de estudo de caso ................................................. 57

Figura 5.2 - Modelo de gestão sustentável da FPCRJ .....................................66 66

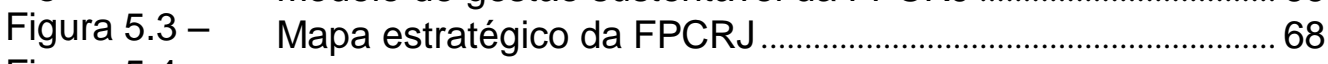

Figura 5.4 - Matriz de materialidade .................................................................. 70 


\section{Lista de Quadros}

Quadro 3.1 - Categorias e aspectos considerados nas Diretrizes G4 da Global

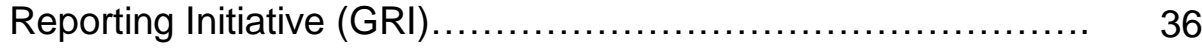

Quadro 3.2 - Quadro comparativo dos referenciais normativos aplicáveis a CDCEC

Quadro 4.1 - Esquema básico da matriz lógica de indicadores de um programa.

Quadro 4.2 - Exemplos de critérios para seleção de indicadores (I)

Quadro 4.3 - Exemplos de critérios para seleção de indicadores (II)....

Quadro 5.1 - Síntese dos resultados do projeto de pesquisa-ação na FPCRJ.

Quadro 5.2 - Síntese da proposição de indicadores-chave (KPI) à luz das Diretrizes GRI.................................................................. 71

Quadro 5.3 - Indicadores estratégicos para o BSC à luz da GRI.................... 72

Quadro 5.4 - Síntese da proposição de indicadores estratégicos para o BSC à luz da GRI

Quadro 5.5 - Indicadores GRI incluídos no BSC da FPCRJ........................... 82

Quadro 5.6 - Ficha de indicadores............................................................. 83 


\section{Introdução}

Os sistemas de medição da sustentabilidade e respectivos indicadores e métricas vêm desde o final da década de 80 ganhando força e sendo foco de inúmeras pesquisas acadêmicas, seja por uma demanda da sociedade ou por força legal que incide sobre empresas e organizações de diferentes setores da economia.

Pode-se entender a medição de desempenho a partir dos sistemas contábeis tradicionais, pelo viés proposto por Kaplan (1984), que sugere que "os sistemas contábeis foram desenvolvidos com base no movimento da administração científica no início do século vinte". Tratavam-se instrumentos de promoção da eficiência nas empresas de produção em massa, em especial aquelas que entregavam produtos relativamente pouco padronizados e com um alto conteúdo de trabalho manual. Kaplan sugere ainda que a "crença nesses sistemas no atual ambiente competitivo, que pode ser caracterizado por produtos menos intensivos em mão-de-obra direta, fornece um quadro inadequado sobre a eficiência e a eficácia da manufatura”. (Kaplan, 1984, p. 96).

As mudanças na tecnologia, competição e ambientes (internos e externos) estão exigindo a revisão dos métodos e procedimentos de monitoramento e avaliação do desempenho global das organizações, em geral. Tais mudanças, por sua vez, vem estimulando a reflexão e a revisão dos sistemas de medição de desempenho de organizações nas mais diversas atividades socioprodutivas (Sink, 1991, p. 28).

Ademais, a responsabilidade social tem sido expressa pelo viés de um fenômeno que exige das organizações a reflexão acerca do seu papel, de suas obrigações e, principalmente, de sua forma de conduzir seus negócios. Trata-se, entretanto, de uma atitude ampla, socialmente responsável e ética em todas as relações, incluindo, mas não somente, com os acionistas, os empregados, a comunidade, os fornecedores, os clientes, os governos e o meio ambiente. 
Nesse contexto, a presente pesquisa buscou desenvolver um modelo de monitoramento e avaliação (MA) voltado para centros de difusão de ciência, educação e cultura (CDCEC), que integra a metodologia consagrada de Balanced Scorecard (BSC), proposta por Kaplan e Norton (2002; 2004), à abordagem de avaliação de sustentabilidade corporativa disseminada pela Global Reporting Initiative (GRI), por meio de suas diretrizes para relato de sustentabilidade (GRI, 2014).

Os CDCEC, além de desempenharem um papel fundamental na divulgação da Ciência propriamente dita, têm funções essenciais, como passar de uma concepção mais passiva do público para uma concepção de interatividade dinâmica do visitante com os experimentos e experiências que o a instituição exibe. A lógica do 'aprender fazendo' substitui a fórmula da aprendizagem contemplativa.

O CDCEC como agência de educação informal, ou mesmo como um ecossistema educativo e cultural deve realizar uma aproximação interativa com a sociedade, estimulando as diversas formas de percepção dos indivíduos. Nessa perspectiva, considera-se de alta relevância um novo olhar sobre o atual modelo de atuação dos centros de difusão de ciência, educação e cultura em geral, levando-se em consideração o lugar que os serviços culturais e de ensino ocupam no setor de serviços em geral e na economia como um todo.

Ressalta-se que até o momento a GRI não divulgou um conjunto de diretrizes setoriais orientadas para CDCEC e organizações congêneres, abrindose, portanto, um espaço de contribuição acadêmica para o aperfeiçoamento de suas ferramentas setoriais.

Visando demonstrar a aplicabilidade do modelo de monitoramento e avaliação (MA) do desempenho sustentável de CDCEC proposto na presente pesquisa, tomou-se como espaço de aplicação a Fundação Planetário da Cidade do Rio de Janeiro (FPCRJ).

Fundada com o objetivo principal de planejar, coordenar, desenvolver e supervisionar projetos e atividades relativas ao ensino, à pesquisa e à divulgação de assuntos de caráter científico, ligados à Astronomia e a Ciências afins e de 
caráter cultural em geral a FPCRJ tem as finalidades de: (i) constituir-se em centro de difusão de ciência, educação e cultura para sistematizar e divulgar conhecimentos científicos; (ii) implantar e manter centros próprios de caráter científico; (iii) propiciar espaços abertos para realizações culturais da comunidade; (iv) manter contatos com entidades públicas e privadas cujas atividades tenham relação direta ou indireta com seus objetivos, visando à coordenação de esforços para consecução dos objetivos comuns; (v) promover o aperfeiçoamento de profissionais das áreas científica e cultural.

Considerando-se o potencial da FPCRJ de consolidar o seu papel como agente de transformação social e seu lugar como espaço livre de acesso e construção do saber, da criatividade e consciência crítica dos cidadãos cariocas, partiu-se do pressuposto de que a aplicação do modelo de MA de desempenho sustentável de CDCEC - objeto desta pesquisa - contribuiria para uma compreensão mais ampla de como essa instituição poderá estabelecer uma dinâmica de gestão necessária à sua sustentabilidade e à garantia da difusão da Astronomia e Ciências afins em todas as classes da população carioca.

Outro aspecto a ser ressaltado é que o monitoramento e avaliação do desempenho da FPCRJ, na perspectiva da sustentabilidade corporativa, mostra-se como um caminho necessário para que seja criada internamente uma atitude favorável à lógica de serviços inovadores, não como resultado da simples modernização de suas atuais atividades, mas como mecanismo que permitirá transformá-la em uma instituição que produz serviços para os quais existem usuários, clientes ou públicos dispostos a adquiri-los de diferentes maneiras.

Como consequência, a FPCRJ poderá alcançar melhores resultados se apoiar seu modelo de gestão em uma atitude comprometida com os seus usuários/clientes/públicos, criando um espaço de diálogo e de troca para melhor perceber o que acontece à sua volta, segundo a visão da sustentabilidade econômica, social e ambiental.

\section{1.}

\section{Definição do problema de pesquisa}

Considerando-se a importância do monitoramento e avaliação do desempenho em sustentabilidade como instrumentos essenciais para a gestão 
efetiva de CDCEC sustentáveis e a necessidade da FPCRJ de dispor de indicadores para monitorar e avaliar a implementação de seu Plano Estratégico 2013-2022, segundo essa visão, definiu-se a seguinte questão principal a ser respondida ao longo da pesquisa:

"Quais indicadores e métricas devem ser adotados para monitorar e avaliar a gestão sustentável de centros de difusão de ciência, educação e cultura?”.

\section{2.}

\section{Objetivos: geral e específicos}

O objetivo geral da pesquisa é propor um conjunto de indicadores e métricas para monitorar e avaliar o desempenho sustentável de centros de difusão de ciência, educação e cultura.

Para alcançar o objetivo geral, estabeleceram-se os seguintes objetivos específicos:

Caracterizar centros de difusão de ciência, educação e cultura e identificar experiências internacionais de CDCEC sustentáveis; Identificar e analisar referenciais normativos de sustentabilidade aplicáveis a CDCEC, tendo em vista a escolha objetiva de indicadores e métricas para esses Centros e organizações congêneres;

Demonstrar a necessidade de se adaptar a metodologia de gestão estratégica Balanced Scorecard para CDCEC que desejam atuar no modo sustentável, considerando-se os preceitos de uma gestão pública moderna com ênfase em resultados econômicos, sociais e ambientais e orientada para o cidadão;

Subsidiar o desenvolvimento de um modelo de monitoramento e avaliação do desempenho sustentável para CDCEC, incluindo os respectivos indicadores e métricas de sustentabilidade econômica, ambiental e social aplicáveis

Demonstrar a aplicabilidade dsse modelo, mediante o desenvolvimento de um estudo de caso na Fundação Planetário da Cidade do Rio de Janeiro.

\section{3.}

Motivação

Os resultados desta dissertação poderão trazer os seguintes benefícios:

- Contribuição para o desenvolvimento pela GRI de um suplemento específico com diretrizes para centros de difusão de ciência, educação e cultura e organizações congêneres em nível internacional; 
- A experiência da FPCRJ poderá servir de base para aplicação em outros CDCEC no Brasil e no mundo, considerando-se que a Fundação integra a Associação Brasileira de Planetários e a Internacional Planetarium Society;

- No âmbito da FPCRJ, a aplicação do modelo de MA propicirá maior transparência e eficiência da gestão estratégica da Fundação com melhorias significativas da comunicação com suas partes interessadas;

- Suporte institucional para que a FPCRJ obtenha certificações de sustentabilidade (como a Leadership in Energy and Environmental Design - LEED e o Programa Nacional de Conservação de Energia Elétrica - Procel) e premiações como o Prêmio Qualidade Rio (PQRio);

- Oportunidade para publicação internacional, considerando o caráter inovador da proposta e o interesse declarado da Internacional Planetarium Society pelos seus resultados.

No contexto institucional no qual a pesquisa se insere, considera-se que os resultados desta pesquisa serão úteis devido a diversos fatores, dentre os quais destacam-se:

- Uma crescente preocupação global com o desempenho sustentável das organizações é fortemente observada;

- Ações e resultados devem se manter transparentes, utilizando indicadores que possibilitem, além do relato de desempenho, um comparativo com outras organizações;

- Com este objetivo, sistemas de medição e avaliação da sustentabilidade como o disseminado pela Global Reporting Initiative, por exmeplo apresentam diretrizes para relatos de sustentabilidade que abrangem a comunicação do desempenho econômico, ambiental e social das organizações junto a suas partes interessadas;

- A Global Reporting Initiative dispõe de suplementos setoriais, nos quais são apresentados orientações específicas direcionadas para atividades desenvolvidas por diversos setores da economia. Esses suplementos setoriais objetivam um melhor e mais amplo relato de desempenho sustentável, porém as atividades de CDCEC e organizações congêneres não foram até o momento contempladas; 
- Espera-se que a alta liderança dessas organizações - CDCEC e organizações congêneres - possa se valer de sistemas de MA tendo como subsídio os indicadores e métricas proposas nesta dissertação para tomar decisões relativas às estratégias de sustentabilidade que adotam.

1.4 .

Metodologia

Quanto aos fins, a pesquisa pode ser considerada descritiva e aplicada. Quanto aos meios de investigação, a metodologia compreende: (i) pesquisa bibliográfica e documental; (ii) análise de experiências internacionais de CDCEC e de referenciais normativos de avaliação da sustentabilidade aplicáveis a CDCEC; (iii) desenvolvimento de um modelo de monitoramento e avaliação (MA) de desempenho sustentável de CDCEC; (iv) aplicação do modelo de MA na FPCRJ, mediante o protocolo de estudo de caso estabelecido por Yin (2005);

(v) discussão dos resultados do estudo de caso; e (vi) formulação das conclusões e recomendações.

A Figura 1.1 apresenta a sequência da pesquisa em suas três grandes fases:

(i) exploratória e descritiva; (ii) pesquisa aplicada; (iii) conclusiva.
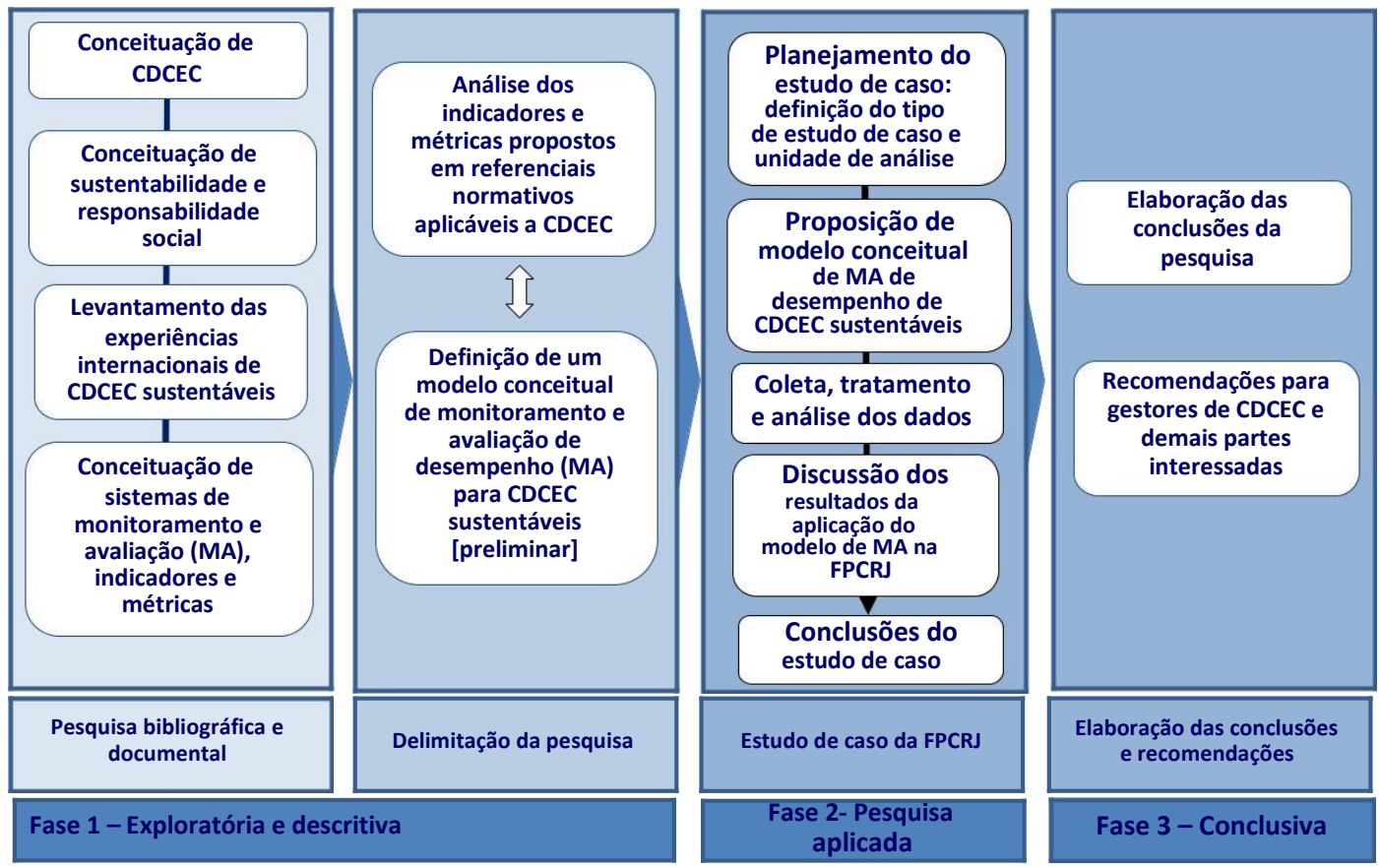

Figura 1.1 - Desenho da pesquisa, seus componentes e métodos Fonte: Elaboração própria. 
Descreve-se, a seguir, cada fase da pesquisa, conforme Figura 1.1.

\subsection{1.}

\section{Fase exploratória e descritiva}

A fase exploratória foi iniciada com uma pesquisa bibliográfica e documental, com o objetivo de levantar trabalhos e estudos sobre o tema central da pesquisa.

Apresenta-se na Figura 1.2 uma visão geral e esquemática dos resultados desta fase, representada no formato de um mapa conceitual, no qual o tema principal e os subtemas específicos contemplados no referencial teórico são interligados para se responder à questão principal da pesquisa (definida no item $1.1)$.

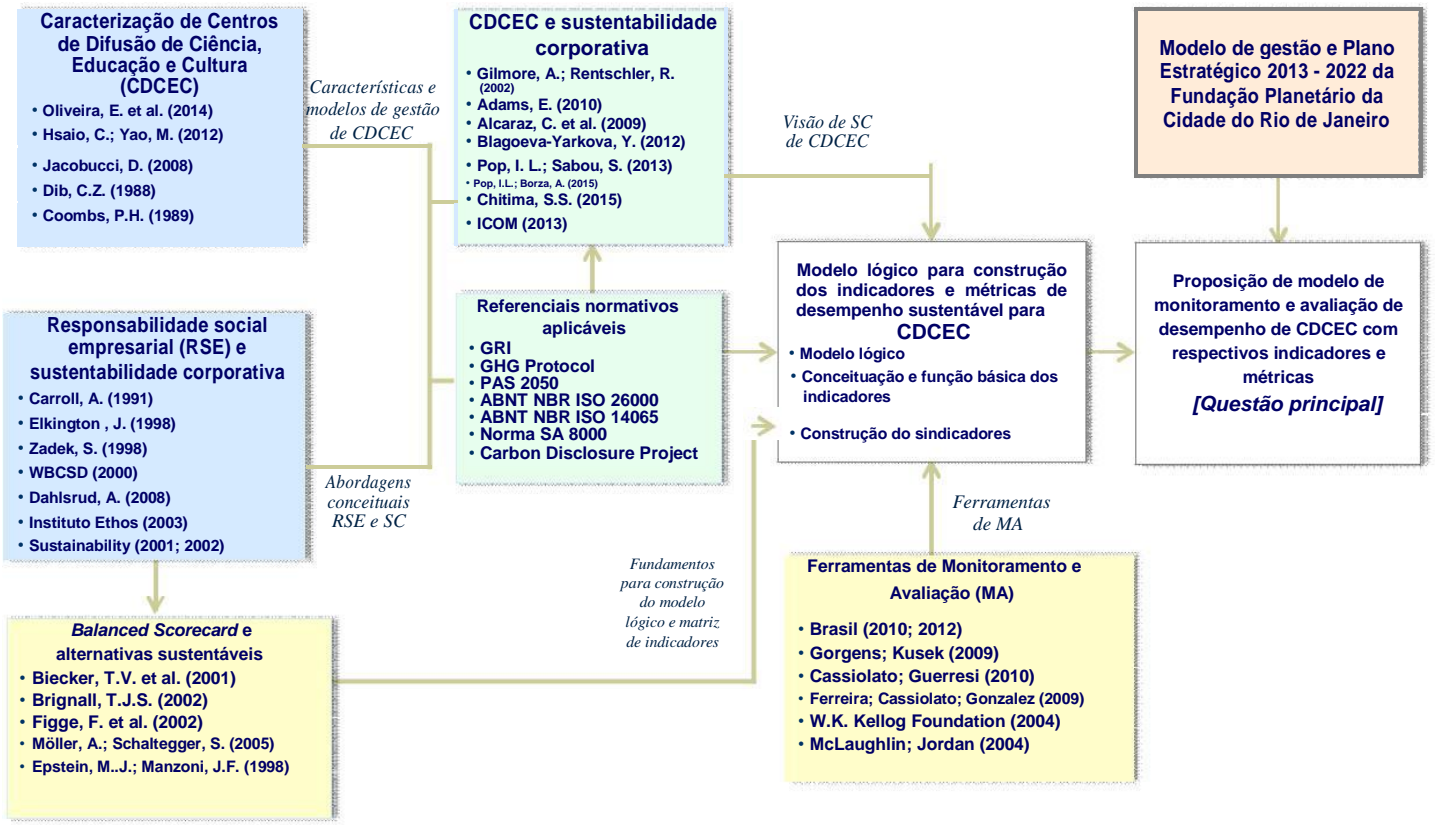

Figura 1.2 - Mapa conceitual da pesquisa Fonte: Elaboração própria.

A partir dos resultados da revisão bibliográfica e documental que nortearam a definição dos objetivos da pesquisa e da análise de experiências internacionais de CDCEC sustentáveis e dos indicadores e métricas já propostos em referenciais normativos aplicáveis a CDCEC, foi possível definir nesta fase, ainda que preliminarmente, um modelo conceitual de monitoramento e avaliação (MA) de desempenho para CDCEC sustentáveis. 


\subsection{2.}

\section{Fase de pesquisa aplicada}

$\mathrm{Na}$ fase de pesquisa aplicada, foram realizadas as seguintes etapas: (i) planejamento do estudo de caso, definindo-se a proposição e questões do estudo de caso e a unidade de análise; (ii) proposição do modelo conceitual de MA de desempenho de CDCEC sustentáveis; (iii) coleta de dados na FPCRJ, tratamento e análise dos dados; (iv) discussão dos resultados da aplicação do modelo de MA na FPCRJ; e (v) conclusões do estudo de caso. Esta parte da metodologia será abordada com mais detalhes no capítulo 5 desta dissertação.

\subsection{3.}

\section{Fase conclusiva}

Nesta fase, formularam-se as conclusões da pesquisa e um conjunto de recomendações à FPCRJ e aos diversos atores interessados na aplicação dos indicadores e métricas propostos, como, por exemplo, a Internacional Planetarium Society, a Associação Brasileira de Planetários e a Global Reporting Initiative. Encaminharam-se nesta fase propostas de estudos futuros, como desdobramentos naturais da presente pesquisa.

\section{5 .}

\section{Estrutura da dissertação}

Esta dissertação encontra-se estruturada em seis capítulos, incluindo esta introdução.

O capítulo 2 apresenta o referencial teórico sobre responsabilidade social e sustentabilidade corporativa, focalizando particularmente trabalhos que discutem a metodologia Balanced Scorecard à luz dos princípios da responsabilidade social e da conceituação de sustentabilidade corporativa. Descreve e discute experiências internacionais de CDCEC sustentáveis, especificamente os casos do Australian Social History Museum (Austrália); do Museu de Ciência Natural (Romênia); e do Californian Academy of Sciences (EUA), como pano de fundo para o desenho preliminar do modelo de monitoramento e avaliação pretendido.

O capítulo 3 apresenta os principais referenciais normativos de sustentabilidade, particularmente as diretrizes para relatos de sustentabilidade estabelecidas pela Global Reporting Initiative; o GHG Protocol; a PAS 2050; a Norma ABNT NBR ISO 26000; a Norma ABNT NBR ISO 26000 e o Carbon 
Disclosure Project, visando identificar indicadores e métricas aplicáveis a CDCEC e organizações congêneres.

O capítulo 4 aborda as atividades de monitoramento e avaliação (MA) como instrumentos fundamentais para a gestão sustentável de CDCEC, abrangendo a elaboração do modelo lógico para construção de indicadores e métricas; a conceituação e função básica dos indicadores e respectivas métricas; e métodos adotados na definição e seleção de métricas, que de fato expressem os resultados esperados da adoção de boas práticas de sustentabilidade econômica, social e ambiental pelas organizações. Destacam-se neste capítulo a metodologia para elaboração do modelo lógico, proposta pelo Instituto de Pesquisa Econômica Aplicada (Ipea) para organizar avaliações dos programas que integram o Plano Plurianual (PPA); e o método de construção de indicadores de MA, divulgado pelo Ministério do Planejamento, Orçamento e Gestão.

O capítulo 5 apresenta o estudo de caso na Fundação Planetário da Cidade do Rio de Janeiro (FPCRJ), que teve por objetivo demonstrar a aplicabilidade do modelo proposto para o monitoramento e avaliação de desempenho sustentável de CDCEC. Apresenta um conjunto de indicadores e métricas, cuja construção integrou a metodologia Balanced Scorecard na perspectiva da sustentabilidade com as diretrizes para relatos de sustentabilidade estabelecidas pela Global Reporting Initiative.

No último capítulo, apresentam-se as conclusões da pesquisa e recomendações para replicação em outros CDCEC e organizações congêneres no Brasil e no mundo, considerando-se que a FPCRJ integra a Associação Brasileira de Planetários e a Internacional Planetarium Society. 


\section{2 \\ Centros de Difusão de Ciência, Educação e Cultura na perspectiva da sustentabilidade}

O termo "Centro de difusão de ciência, educação e cultura" tem sido utilizado atualmente por pesquisadores em Educação, professores de diversas áreas do conhecimento e profissionais que trabalham com divulgação científica para descrever lugares, diferentes da escola, onde é possível desenvolver atividades educativas e culturais (Jacobbucci, 2008). Dentre essas instituições, podem ser incluídos os espaços que são regulamentados e que possuem equipe técnica responsável pelas atividades executadas, sendo o caso dos Museus, Centros de Ciências, Parques Ecológicos, Parques Zoobotânicos, Jardins Botânicos, Planetários, Institutos de Pesquisa, Aquários, Zoológicos, dentre outros.

Os centros de ciências brasileiros surgiram a partir de projetos oficiais do Governo Federal voltados para a melhoria do ensino de ciências na década de 1960 (Gouveia, 1992). Pode-se observar o surgimento de uma quantidade significativa de centros de ciências a partir de 1980, tendo como ponto de partida a criação em 1954, São Paulo, do Instituto Brasileiro de Educação, Ciência e Cultura, o IBECC, que, na época, se vinculava à Universidade de São Paulo e à Organização das Nações Unidas para a Educação, Ciência e Cultura (UNESCO), sendo ainda hoje responsável pela gestão do Projeto Cientista do Amanhã (http://www.cientistasdeamanha.com). O IBECC tinha como objetivos prioritários a melhoria do ensino de ciências e a introdução do método experimental nas escolas de $1^{\circ}$ e $2^{\circ}$ graus da época (Fracalanza, 1993).

Sendo assim, para efeitos deste estudo, entende-se que espaço não-formal de educação abrange a idéia de que o processo que envolve o desenvolvimento científico é um processo cultural, quer seja ele considerado do ponto de vista de sua produção, de sua difusão entre pares ou na dinâmica social do ensino e da educação, ou ainda do ponto de vista de sua divulgação na sociedade para o estabelecimento das relações críticas necessárias entre o cidadão e os valores 
culturais, de seu tempo e de sua história.

\section{1.}

\section{Responsabilidade social}

As bases do conceito moderno de responsabilidade social foram lançadas por representantes do World Business Council for Sustainable Development, em 1998, na Holanda:

[...] responsabilidade social no nível das organizações é o comprometimento permanente de seus líderes de adotar um comportamento ético e contribuir para o desenvolvimento econômico, melhorando, simultaneamente, a qualidade de vida de seus empregados e de suas famílias, da comunidade local e da sociedade como um todo (WBCSD, 2000, p.2).

O Relatório, elaborado pela Comissão Mundial sobre o Meio Ambiente e o Desenvolvimento, faz parte de uma série de iniciativas, anteriores à Agenda 21, as quais reafirmam uma visão crítica do modelo de desenvolvimento adotado pelos países industrializados e reproduzido pelas nações em desenvolvimento, e que ressaltam os riscos do uso excessivo dos recursos naturais sem considerar a capacidade de suporte dos ecossistemas. Como resultado dessas discussões, propôs-se, em 1987, o documento denominado de "Nosso Futuro Comum", que mais tarde ficou conhecido como relatório de Brundtland, em homenagem a então primeira-ministra da Noruega.

Neste sentido, a idéia de desenvolvimento sustentável foi definida no relatório supracitado como "o desenvolvimento que satisfaz as necessidades presentes, sem comprometer a capacidade das gerações futuras de suprir suas próprias necessidades".

O conceito de sustentabilidade ainda é de difícil entendimento ou concenso, pois atende a um conjunto de variáveis interdependentes, mas os diferentes conceitos atuais geralmente englobam a capacidade de integrar as questões sociais, econômicas e ambientais. Entretanto, nem sempre foi aceito dessa forma, o que gerou inúmeros conflitos (alguns ainda persistem) com ambientalistas e ecologistas. 


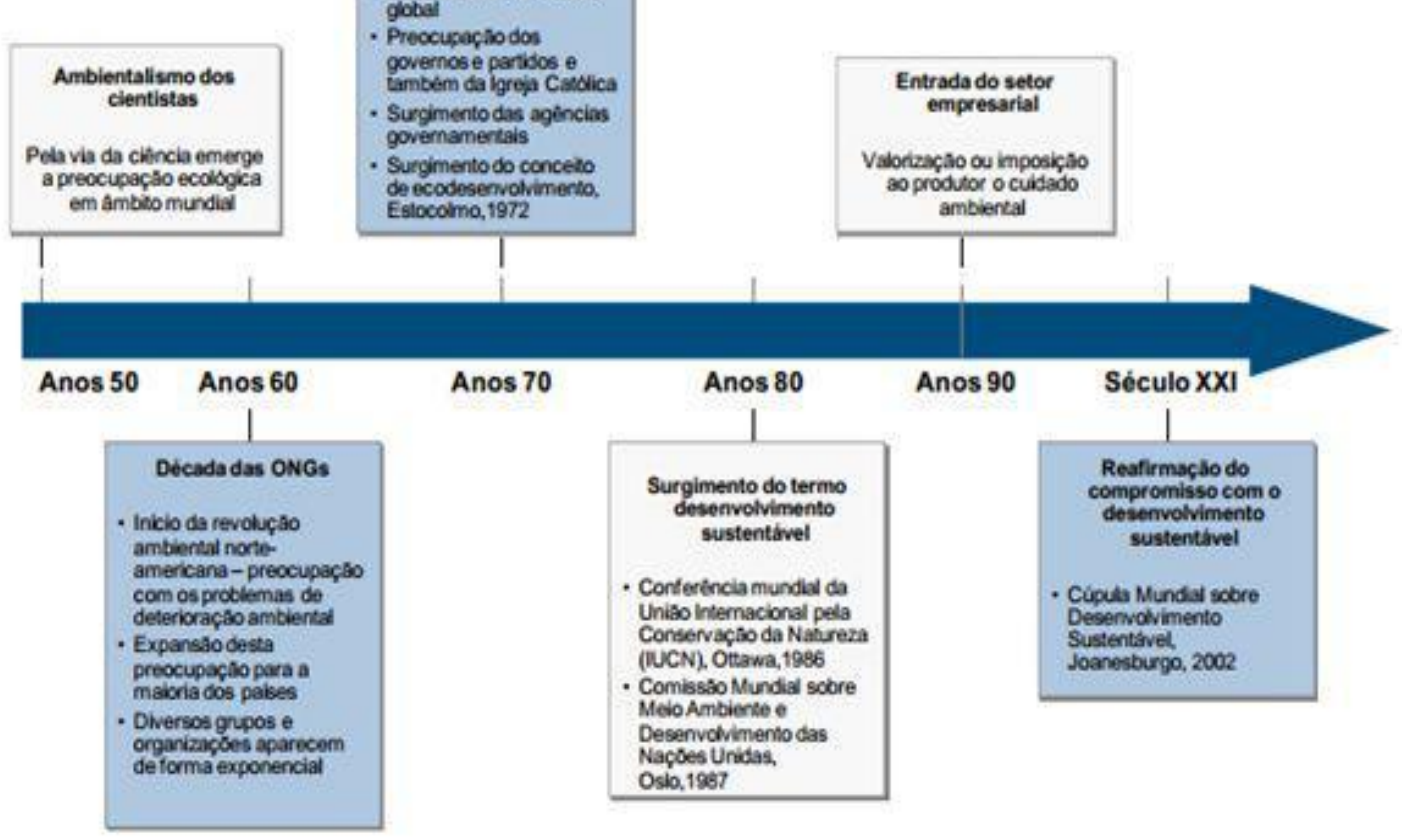

Figura 2.1 - Origens, características e expansão do movimento ambientalista. Fonte: MONTIBELLER (2004)

Desde os anos 90, houve-se um entendimento de que sustentabilidade ambiental é inseparável das questões e da sustentabilidade econômica e social, neste período, John Elkington (1999) já havia publicado sua teoria, conhecida como "Triple Bottom Line", onde sustenta que os resultados de uma organização devem ser medidos em termos sociais, ambientais e econômicos.

Com o avanço deste conceito, inúmeras organizações incorporaram em seus relatórios de desempenho, informações acerca de responsabilidade social e sustentabilidade, sob a perspectiva do Triple Bottom line, no entanto, com o intuito de não sucumbir a modismos vazios de conteúdo e acabar endossando uma sustentabilidade aparente (greenwashing), segundo Bowen (2004), deve-se exigir de inúmeros discursos, propostas, projetos e programas adjetivados com estas palavras, a definiçãa do que se entende pelo conceito e dados concretos de resultados, para que seja passível de comparação com outras iniciativas. Bowen (2004) sugere ainda que seja possível que neste campo um dia se alcance a proteção do consumidor e dos cidadãos através de algo similar a uma bula de 
remédio, com indicações, contra indicações e efeitos colaterais.

Outra definição, formulada pelo Instituto Ethos de Empresas e responsabilidade Social, complementa a anterior e refere-se à responsabilidade social como:

[...] a forma de gestão que se define pela relação ética e transparente da organização com todos os públicos com os quais se relaciona e pelo estabelecimento de metas de negócio compatíveis com o desenvolvimento sustentável da sociedade, preservando recursos ambientais e culturais para gerações futuras, respeitando a diversidade e promovendo a redução das desigualdades sociais (Instituto ETHOS, 2003).

Em ambas definições, como pode ser observado, o conceito de responsabilidade social está sempre associado ao engajamento das partes interessadas e à sustentabilidade corporativa nas dimensões econômica, social e ambiental. De fato, esse conceito tem se consolidado de maneira sistêmica multidimensional, com ênfase na interdependência e interconectividade entre os diferentes públicos de interesses relacionados, diretos ou indiretamente, aos negócios da organização.

Carroll (1999), em seu artigo "Corporate Social Responsability", sugere que, “(...) na literatura, o conceito de responsabilidade social não se alterou ao longo do tempo, no entanto, o que mudou são as questões enfrentadas pelas organizações, bem como as práticas de responsabilidade social, principalmente, devido às mudanças ocorridas na sociedade e nas empresas, e, conseqüentemente, nas relações entre elas."

As demandas sociais por melhoria das condições de vida da população são geradas constantemente pela sociedade, visando melhorias em educação, infra-estrutura, saúde e lazer, entre outros, que, espera-se, deveriam ser proporcionadas à população através das ações do poder público. Na visão de Melo Neto e Froes (2001), o Estado deve ser o principal responsável por implantá-las, contudo, em face das limitações da ação do governo, abre-se espaço para que outros agentes atuem.

Nesse sentido, Drucker (2002) argumenta que as empresas devem atuar de maneira socialmente responsável, pois estas têm direitos, deveres e obrigações, não se admitindo mais a produção e comercialização de bens e serviços sem a observância aos princípios morais, à postura ética e ao respeito aos conceitos de cidadania. 
Segundo Bossel (1998, 1999), só existe uma alternativa à sustentabilidade, que é a insustentabilidade. E o conceito de desenvolvimento sustentável envolve a questão temporal, sendo assim a sustentabilidade de um sistema só pode ser observada a partir da perspectiva futura, de ameaças e oportunidades.

\section{2.}

\section{Balanced Scorecard na perspectiva da sustentabilidade}

Balanced scorecard ou BSC é uma ferramenta de planejamento estratégico e avaliação de desempenho global que se consagrou nas últimas décadas como um sistema de gerenciamento estratégico, comunicação e medição dos resultados das mais diversas organizações - empresas, agências governamentais, prefeituras e instituições de comunicação, tecnologia e informação - CT\&I. Sua implementação facilita a criação uma visão holística dos objetivos de longo prazo a serem atingidos nos mais diversos níveis da organização. Comparando-se com os sistemas de medição convencionais, baseados exclusivamente na vertente financeira, o BSC é capaz de direcionar a organização para a sua visão de futuro, definindo quais os objetivos a atingir e medindo sues resultados a partir de quatro perspectivas distintas (Kaplan e Norton, 2004).

Segundo seus autores, Kaplan e Norton, o objetivo principal do BSC é fazer com que a força de trabalho seja capaz de entender e implementar as estratégias da organização, pelo entendimento dos indicadores de resultado, tanto financeiros, como não financeiros. Por meio de um processo participativo, vertical e horizontal,, deve se construir um "mapa estratégico", no qual se destacam os objetivos e indicadores que são críticos para a geração de valor para as diversas partes interessadas, particularmente os acionistas. Por essa razão, o BSC tem sido considerado um poderoso mecanismo de comunicação institucional e harmonização de interesses distintos.

As medidas financeiras proporcionam às organizações uma resposta no curto prazo, e as medidas não-financeiras são as que sustentam as vantagens competitivas de hoje e criam novas para o longo prazo, trazendo expectativas de um futuro sustentável. Nessa perspectiva, o modelo BSC utiliza quatro dimensões 
para mensuração do desempenho global da organização: (i) financeira; (ii) mercado; (iii) processos internos; e (iv) crescimento e aprendizagem.

Não obstante o sucesso experimentado por Kaplan e Norton na aceitação do conceito de BSC, autores como Bieker (2001), Figge et al. (2002) e Brignall (2002) argumentaram, na época, que o uso dos recursos financeiros e humanos de forma eficiente já não se apresentava mais como o único fator determinante e suficiente para promover vantagem competitiva nas organizações (como havia sido preconizado pelos criadores do BSC). Na visão desses autores, cada vez mais os aspectos intangíveis, como por exemplo, o desempenho ambiental e a atuação social, se tornam igualmente importantes e, alguns casos, até mais importantes. Apesar disso, ainda são poucos os trabalhos e modelos que exploram as relações de caso e efeito entre as metas ambientais e sociais e as metas econômicofinanceiras.

Nessa linha, citam-se as iniciativas da SustainAbility, em nível internacional, e do Instituto Ethos, no Brasil, essencialmente baseadas na chamada matriz de evidências. Essa matriz busca mostrar as relações entre as três dimensões da abordagem triple bottom line de Elkington (1998) e, principalmente, evidenciar o potencial de benefícios econômicos a ser explorado pelas práticas ambiental e socialmente responsáveis (SustaiAbility, 2001; 2003; Instituto Ethos, 2004).

Nesse contexto, os autores Bieker (2001), Brignall (2002) e Figge et al. (2002) lançam um novo olhar sobre a ferramenta BSC, buscando mostrar como as organizações podem se beneficiar de seu uso, incorporando adaptações ao conceito original. A falta de integração entre as três dimensões (econômica, social e ambiental) no BSC convencional representa um grande obstáculo para que as organizações incorporem as ações de responsabilidade social (RS) em suas estratégias de forma efetiva. A criação de um BSC sustentável permite considerar e implementar os aspectos ambientais e sociais por toda a organização e com a visão estratégica, comunicando e transformando a RS em uma ação constante, planejada e passível de mensuração.

Para integrar os aspectos ambientais e sociais ao BSC convencional, Figge et al. (2002) sugerem três alternativas, a saber: (i) incorporação das dimensões ambiental e social em três das perspectivas originais do BSC; (ii) 
criação de uma quinta perspectiva exclusiva para as dimensões ambiental e social; e (iii) criação de um BSC exclusivo para a sustentabilidade ambiental e social, porém dependente de uma das alternativas anteriores.

Na primeira alternativa, promove-se a integração das questões ambientais e sociais relevantes em três das quatro perspectivas do BSC convencional, que passam a ser traduzidas em objetivos, metas e indicadores estratégicos vinculados ao cumprimento da missão e aos planos de negócio de curto, médio e longo prazo. Essas novas questões tornam-se parte integrante do BSC, como um todo, o que facilita a compreensão por parte dos gestores e da força de trabalho das relações de causa e efeito entre as questões ambientais, sociais e econômicas. De acordo com os autores, os objetivos e metas orientam-se hierarquicamente para a perspectiva financeira, convergindo para uma estratégia bem sucedida de negócio com triplo resultado (sustentabilidade econômica, social e ambiental), como preconizado por Elkington na sua matriz de evidências (SustainAbility, 2001; 2003).

Na sequiência, descreve-se a segunda alternativa proposta por Figge et al., que consiste na criação de uma quinta perspectiva exclusiva para as dimensões ambiental e social, além das quatro do BSC convencional. Nessa segunda alternativa, Figge et al. (2002) ressaltam que a necessidade da criação de uma nova perspectiva (social e ambiental) surge quando os aspectos ambientais e sociais não podem ser refletidos simultaneamente dentro das quatro perspectivas, devido às características dos objetivos gerados. No entanto, a relação de causalidade é mantida, visto que a relação de causa-efeito é realizada de forma direta com a perspectiva financeira e de forma indireta com as outras perspectivas, integrando os aspectos ambientais e sociais à estratégia da organização.

A terceira possibilidade aponta para a geração de um BSC criado para as questões ambientais e sociais, de forma separada do BSC sustentável principal, porém totalmente dependente de uma das duas alternativas anteriores.

A conceituação de cada alternativa reflete a diferença fundamental entre as três propostas. Enquanto as duas primeiras integram os aspectos ambientais e sociais ao BSC convencional (com criação ou não de uma quinta dimensão), a terceira constitui uma variante derivada das anteriores. A terceira proposta configura-se como um passo posterior à adoção de um primeiro BSC sustentável, 
quase como um refinamento dessa primeira solução.

Sobre as duas primeiras alternativas, Figge et al. (2002) argumentam que elas não são mutuamente excludentes, podendo ser utilizadas simultaneamente de acordo com as características dos objetivos estratégicos ambientais e sociais definidos pela empresa. Dessa forma, pode-se concluir que a opção de uma determinada organização por uma ou alternativa de BSC sustentável depende, substancialmente, do contexto socioprodutivo na qual está inserida, do seu relacionamento com as diversas partes interessadas (stakeholders) e do seu estágio de maturidade organizacional.

\section{3.}

\section{Um novo olhar sobre o modelo de gestão de CDCEC}

O aumento da concorrência e a necessidade de otimização do uso de recursos levaram os CDCEC a repensarem sua missão de servir ao público com uma visão de satisfação dos visitantes no longo prazo (Hsiao e Yao, 2012). Particularmente, nos casos de museus, Gilmore e Rentschler (2002) ressaltam que a gestão desses centros tem sido cada vez mais orientada para satisfazer as necessidades de seus públicos-alvo. Esses autores argumentam que, como os museus são instituições sem fins lucrativos que dependem de aportes financeiros do governo, muitas vezes em até $70 \%$ de seus orçamentos, eles devem expressar em suas proposições de valor a responsabilidade social e atrair um número crescente de visitantes de diferentes públicos.

Enfatiza-se, portanto, para fins deste trabalho, a necessidade dos CDCEC incorporarem critérios sociais e ambientais no nível normativo da gestão estratégica de seus negócios, traduzindo-os em objetivos e metas, cujos alcances possam ser computados na avaliação de seu desempenho global.

O International Council of Museums (ICOM) reforça esse argumento, ao ressaltar que a finalidade maior de qualquer museu é servir às pessoas e ao desenvolvimento da sociedade: "um museu é uma instituição sem fins lucrativos, prestando permanentemente serviços à sociedade para seu desenvolvimento. Aberto a diferentes públicos adquire, conserva, pesquisa, divulga e expõe para fins de estudo, educação e lazer, evidências tangíveis e intangíveis das pessoas e seu ambiente" (ICOM, 2013). 
De acordo com Andoniadis (2010) e Bagdali e Polino (2006), os CDCEC moderno devem criar valor para seus visitantes através da introdução rápida de inovações, da oferta de produtos e serviços de alta qualidade em função das necessidades de diferentes públicos e horários estendidos de acesso. Diferenciação de serviços e estratégias de diversificação propiciam a esses centros a ampliação do número de visitantes e da capacidade de geração de sua própria renda.

Qualidade e inovação têm sido consideradas como fontes de vantagens competitivas sustentáveis (Radder et al., 2011) e, partindo-se desse pressuposto, os CDCEC têm revisto seus indicadores-chave de desempenho na perspectiva de autossustentabilidade financeira e responsabilidade social (Maher et al., 2011). Além disso, quaisquer serviços prestados em conformidade com os requisitos de qualidade com foco nos visitantes, contribuem para que os CDCEC possam cumprir suas metas de responsabilidade social e, ao mesmo tempo, aumentem suas receitas próprias na direção da autossustentabilidade financeira (Marković et al., 2013). Portanto, os modelos de gestão sustentáveis que vêm sendo desenvolvidos e implementados por CDCEC enfatizam as expectativas de seus vários stakeholders e a mensuração de um desempenho sustentável (Radder e Han , 2013; Misiura, 2005; Hsiao e Yao, 2012).

Recentemente, novembro de 2014, um estudo, coordenado pela Fundação Brasileira para o Desenvolvimento Sustentável que versa sobre os rumos da sustentabilidade no Brasil foi apresentado. Intitulado de Diretrizes Para uma Economia Verde, esta obra apresenta indicadores para seis setores da atividade econômica sob o olhar da sustentabilidade.

Os especialistas brasileiros de várias vertentes, como Holtz (2005) mostram os desafios que o Brasil ainda precisa enfrentar, além do desmatamento. Com base em dados econômicos e da história de políticas públicas, começam a projetar quais seriam os possíveis caminhos a serem debatidos pelas cidades brasileiras e a serem tomados pelo Brasil em relação ao seu desenvolvimento. Neste contexto, inserem-se os centros de difusão de ciências, educação e cultura como importantes agentes de transformação social.

Diversos documentos importantes que tratam da sustentabilidade de Centros de Difusão de Ciência, Educação e Cultura - CDCEC, como museus ou outros congêneres, quando específicos a este setor, tratam de arquitetura 
sustentável ou ainda de modelos de geração de receita, como será demonstrado nos capítulos seguintes.

\section{4 . \\ Experiências internacionais de CDCEC sustentáveis}

A questão ambiental impôs-se como um problema premente no final da década de sessenta. Percebe-se como reflexo dessa preocupação com o ambiente, as diversas cartas, convenções e recomendações internacionais da época, que se constituem como as primeiras tentativas organizadas a nível mundial para a preservação do património natural.

Diversas iniciativas têm sido experimentadas ao longo dessas ultimas décadas e, tendo ou não sucesso em relação à sua proposição inicial, as lições aprendidas configuram-se um manancial de conhecimentos e saberes à disposição de pesquisadores e estudiosos.

Neste capítulo aborda-se alguns casos internacionais que ilustram tais iniciativas.

\subsection{1.}

\section{Caso da Austrália}

Adaptado da definição proposta no relatório de Brutland (1987), a sustentabilidade corporativa foi largamente utilizada com o significado de uma organização dispor de recursos suficientes para manter a existência e cumprir os seus objetivos para o futuro e responsabilidade social corporativa, definida por Cabral-Cardoso (2002) como a forma de gestão que se define pela relação ética e transparente da empresa com todos os públicos com os quais ela se relaciona e pelo estabelecimento de metas empresariais que impulsionem o desenvolvimento sustentável da sociedade, preservando recursos ambientais e culturais para as gerações futuras, respeitando a diversidade e promovendo a redução das desigualdades sociais, passa a ser entendida como um elemento vital para o desenvolvimento dos negócios e para estabelecer relações positivas das empresas com as assim chamadas partes interessadas (stakeholders). Incitando-se assim as empresas a adotar novas posturas diante de questões relacionadas à ética e à qualidade da relação formada entre as mesmas e a sociedade. 
Em 2009, foi publicado um estudo (Alcaraz, C. et al.) cujo principal objetivo foi a identificação de problemas que podem ajudar na criação da sustentabilidade em museus. Este trabalho se concentra especificamente na pesquisa com os usuários incluindo a experiência de serviço e foi baseada na necessidade de aumentar a visitação e satisfação.

Alcaraz (2009) sugere ainda que a sustentabilidade de um museu é questionável no longo prazo, com uma necessidade de mudança fundamental nos modos mentais e atitudes assumidas na gestão do setor em particular e reforça a necessidade de marketing ser mais eficaz e as estratégias mais adequadas, de forma geral.

Percebe-se que tal iniciativa gerou um movimento de pensar a responsabilidade e o papel dos museus e centros de difusão de ciências como vetor para o empoderamento da população no que tange aos conceitos, atitudes e práticas cotidianas de sustentabilidade, no entanto, não se pode deixar de observar que no caso do Australian Social History Museum:

O foco da sustentabilidade centrava-se na autossustentabilidade financeira.

A metodologia adotada para a definição das estratégias corporativas foi baseada no Balanced Scorecard, no entanto o olhar sobre a dimensão clientes ganhou maior relevância devido o entendimento de que este é o vetor foco dos museus, e apresentava grande carência de acompanhamento.

Não foi definido indicadores e métricas de acompanhamento do desempenho sustentável das instituições partícipes.

\subsection{2.}

\section{Caso da Romênia}

O papel que organizações culturais, científicas e educacionais desempenham no desenvolvimento urbano para o aumento da competitividade das cidades tornou-se cada vez mais importante nos últimos anos. 
Segundo Corbos, R. A. e Popescu, R. I (2012)., o aumento do número de visitantes deve ser um objetivo fundamental para a estratégia de desenvolvimento das cidades, pois estes "muitos pequenos investidores" não trazem apenas recursos, mas também determinam uma melhora na "oferta urbana". Neste contexto, tais organizações devem se constituir como uma importante opção estratégica para a realização deste objetivo.

O composto denominado de "desenvolvimento de cidades", trás intrínseco a idéia de desenvolvimento sustentável, e Corbos , R. A. e Popescu, R. I (2012), em seus estudos propõem ações de melhoria e estabelece um modelo de desenvolvimento para o Museu Nacional de Arte da Romênia, focado em estabelecer laços com os usuários, integrando novas ofertas e uma reciclagem nos conceitos de museu, fugindo do tradicional "local onde se guarda objetos velhos".

O desenvolvimento sustentável de uma região depende da sustentabilidade e as medidas tomadas por todas as organizações públicas e privadas na área respectiva. Museus destacam-se entre estas organizações devido às controvérsias e dados relacionados com o papel que eles têm de desempenhar neste processo de desenvolvimento sustentável.

Em 2015, Pop I. L. e Borza, A. (2015), realizaram um estudo na Romênia, onde entrevistaram especialistas em museus e centros de difusão de ciências, em especial do Museu de História Natural e relataram que todos os participantes na entrevista consideram que é importante para os museus serem sustentáveis. O que difere significativamente de um desses especialistas para o outro é a sua opinião acerca da sustentabilidade. Dos cinco especialistas entrevistados, apenas um identificou todos os componentes da sustentabilidade, ou seja, o componente sócio-cultural, o componente financeiro e o natural componente ambiental; dois dos peritos identificaram apenas os componentes culturais e financeiros, enquanto que os outros três entendem a sustentabilidade associada apenas com a existência dos recursos necessários para o funcionamento de um museu.

No entanto, na revisão bibliográfica não foi encontrada nenhuma aplicação prática do conceito de sustentabilidade tríplice, como proposto por Elkington, J em 1998. 


\subsection{3}

\section{Caso da Califórnia - EUA}

A cada ano, a Canadian Museum Association - CMA realiza uma premiação para celebrar e incentivar a excelência no setor. Composta por um júri voluntário, a CMA realiza uma análise de todas as apresentações e os que se destacam por sua atuação são homenageados na conferência nacional da associação. Esta iniciativa é a mais importante para os CDCEC canadenses.

No entanto, destaca-se nesse contexto, outra importante iniciativa, o Canadian Green Building Awards. Premiação canadense em construções sustentáveis, onde podem concorrer quaisquer tipo de construção, desde museus à residências, não sendo observada a participação dessa primeira categoria de forma expressiva, apesar de alguns museus, como o Canadian War Museum já ter recebido premiação equivalente no quesito edifício sustentável, conforme a página oficial do local.

Observa-se constantemente a pequena participação de CDCEC e organizações congêneres atuantes em projetos e programas que fujam do seu objetivo inequívoco, no entanto o papel do museu se estende além dos limites físicos de sua edificação, podendo atuar na promoção do desenvolvimento sustentável da região onde está inserido. Como exemplo dessa atuação, em 1998, o Canadian Museum of Nature $(\mathrm{CMN})$ com sede em Ottawa, Canadá, através de parcerias com agências governamentais, instituições educacionais e grupos comunitários, foi pivô de um estudo multidisciplinar, com duração de aproximadamente três anos, de avaliação da biodiversidade do Rio Rideau.

O Projeto da Biodiversidade do Rio Rideau visava avaliar cerca de 100 $\mathrm{km}$ da extensão do rio e trabalhar com as comunidades, com programas de conscientização, para garantir o uso sustentável e a conservação dos recursos biológicos do rio no longo prazo (Poulin, 2001).

Tal iniciativa demonstra o potencial de abrangência de atuação de um museu, bem como sua pouco explorada capacidade de transformação social. Demonstra também que iniciativas qualificadas em direção ao desenvolvimento sustentável emergem de uma demanda que não consegue mais se manter reprimida.

Apesar de tantas iniciativas laudáveis, percebe-se que não há, de forma 
geral, um modelo de avaliação ou ainda, um arcabouço de indicadores e métricas de desempenho em sustentabilidade capaz que abranger um grande número de CDCEC e instituições congêneres, afim de que possibilite uma troca de experiências e avaliações globais que demonstrassem com clareza a evolução da temática do desenvolvimento sustentável no setor.

\section{5 .}

\section{Considerações finais sobre o capítulo}

As discussões sobre a sustentabilidade sócioambiental tornaram-se urgentes e é neste sentido que os centros de difusão de ciência, educação e cultura devem se inserir, utilizando suas ferramentas de comunicação, informação e educação para proporcionar o entendimento e uma consciência social.

Os Museus, Planetários, Institutos de zoobotanica e assemelhados podem trazer diferentes olhares e contrapontos sobre as questões sócioambientais, uma vez que se encontram em um posicionamento relativamente 'livre' de pressões comerciais, por serem de forma geral, subsidiadas por recursos públicos e podem proporcionar a população uma visão realista da necessidade das comunidades e consumidores, articulando-se em torno do exercício organizado da cidadania.

Para trazer o conceito de sustentabilidade do campo das idéias e torná-la algo concreto, passível de medição e ainda comparação, ao longo dos anos surgiram diversas iniciativas e metodologias de avaliação de desempenho corporativo sustentável.

Destaca-se a aplicação da ferramenta BSC para estabelecer o Planejamento Estratégico sustentável de CDCEC, por transmitir de forma clara e direta as ações necessárias para o alcance dos objetivos estratégicos.

Inúmeras iniciativas tentam um modelo para medição dos resultados de sustentabilidade dentro de diversos setores e segmentos: aviação, alimentos, transporte, petróleo e gás, entre outros, no entanto, nenhum que se aplicasse de maneira satisfatória para os CDCEC, que fosse ampla o suficiente para que se estabelecesse como parâmetro de comparação entre tais instituições. 


\section{Referenciais normativos aplicáveis a CDCEC sustentáveis}

Este capítulo tratará da descrição e da análise individual de sete ferramentas, normas e referenciais normativos aplicáveis a CDCEC para realização de um estudo comparativo sobre indicadores de sustentabilidade e servirá de base para a elaboração do modelo conceitual para o estudo de caso.

Essas ferramentas foram observadas considerando seus antecedentes históricos, seus fundamentos teóricos e sua aplicação prática para que se pudesse construir uma visão crítica dos principais aspectos que as caracterizam.

O relato de sustentabilidade deve auxiliar as organizações, empresas e governo a estabelecer metas, definir os pilares que suportem as atividades de negócios e aferir desempenhos, bem como gerir mudanças com vistas a tornar suas operações mais sustentáveis. Tais relatórios de sustentabilidade divulgam informações sobre os impactos de uma organização, sejam positivos ou negativos, sobre o meio ambiente, a sociedade e a economia. Assim, eles dão a forma tangível e concreta como desejo expresso pela sociedade, a questões abstratas, ajudando as organizações a compreender e gerir melhor os efeitos do desenvolvimento da sustentabilidade sobre suas atividades e estratégias.

Procurou-se abordar os principais aspectos, distintos e semelhantes, das diferentes metodologias estudadas.

\section{1.}

\section{Global Reporting Initiative}

Constituída em 1997 pela Coalition for Environmentally Responsible Economies (CERES), em uma parceria com o Programa de Desenvolvimento das Nações Unidas, as Diretrizes GRI para Relato de Sustentabilidade oferecem princípios, conteúdos e um manual de implementação para que diferentes organizações, a despeito de seu porte, setor ou localização, possam elaborar relatórios de sustentabilidade. Tais diretrizes compõem, também, um guia internacional para todos os interessados na divulgação de relatos sobre a forma de 
gestão das organizações, focalizando seus desempenho ambiental, social e econômico bem como os impactos nessas áreas (GRI 2013).

Apresentado como um guia referencial desenvolveu-se por meio de um processo que envolveu consulta a diversos representantes das partes interessadas, dentre os quais emissários de empresas, trabalhadores, sociedade civil, mercados financeiros, auditores e especialistas em diversas áreas. Pode-se afirmar ainda que se constituem, também, como produtos de intenso diálogo com agências reguladoras e governamentais de diversos países, além de serem desenvolvidas em conformidade com documentos internacionalmente reconhecidos sobre a elaboração de relatórios.

As diretrizes GRI estabelecem um marco internacional relevante em apoio a uma abordagem sistematizada e padronizada para a confecção de relatórios, elevando o grau de transparência e consistência que se percebe como necessário para tornar as informações confiáveis e úteis para os diversos mercados e a sociedade como um todo, tornando-se a metodologia de maior aceitação dentre as organizações que atualmente elaboram relatórios de sustentabilidade de suas ações e processos e foram desenvolvidas para serem universalmente aplicáveis a todas as organizações, de grande, médio ou pequeno porte, em todo o mundo (GRI 2013).

Cabe ressaltar que a GRI não foi o primeiro modelo desenvolvido com este objetivo, no entanto, devido suas características mais marcantes, simplicidade, liberdade quanto a forma do relato e grau de aprofundamento escalonado, tornou-se referência para as organizações que desejam relatar suas ações de RS e sustentabilidade (Brown et al., 2007).

Em 2013, a Global Reporting Initiative lançou uma revisão de suas diretrizes, então denominadas de “G3”. De acordo com GRI (2013), a versão "G4" inclui referências a relatórios de sustentabilidade amplamente aceitos e utilizados, tendo sido concebida como uma grade analítica consolidada para reportar o desempenho sustentável de organizações de diferentes setores à luz de diferentes códigos e normas para relatórios de sustentabilidade.

O quadro abaixo sintetiza as categorias e aspectos abordados. 
Quadro 3.1 - Categorias e aspectos considerados nas Diretrizes G4 da Global Reporting Initiative (GRI)

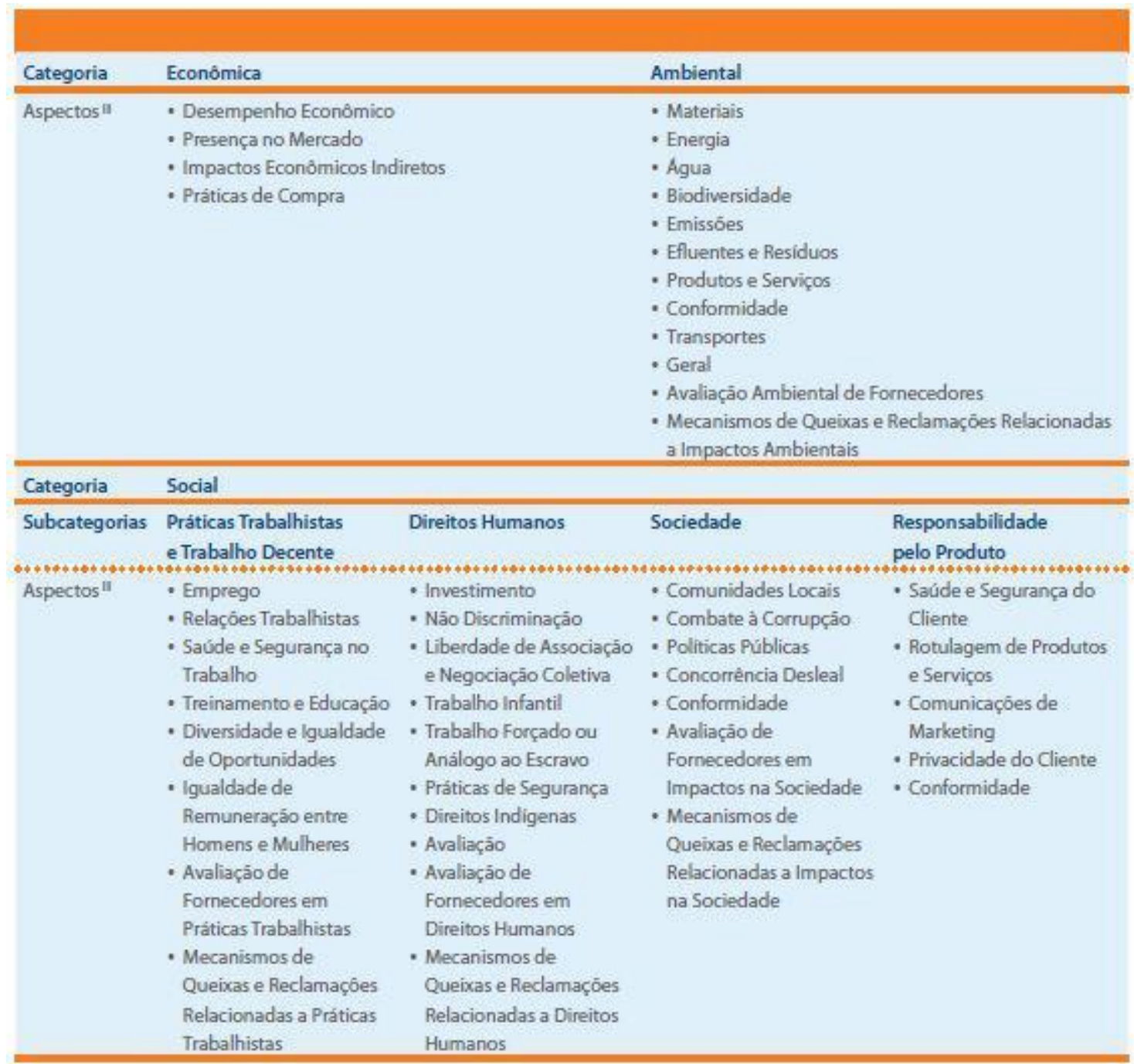

Fonte: GRI (2013)

A GRI propõe 103 indicadores diferentes e não obrigatórios, em alguns dos quais avalia os investimentos no público interno da empresa. Seus indicadores são agrupados nas três dimensões que convencionalmente definem o desenvolvimento sustentável: econômica, ambiental e social.

A GRI desenvolveu guias específicos para alguns setores, denominados de "Guias setoriais", no entanto, estes guias não contemplam CDCEC, configurando-se uma lacuna a ser preenchida. 


\section{2.}

\section{GHG Protocol}

Desenvolvida em meados de 1998, pelo World Resources Institute (WRI), com sede nos Estados Unidos, o GHG Protocol é uma das mais importantes ferramenta utilizada para entender, quantificar e gerenciar emissões de Gases de Efeito Estufa - GEE sendo atualmente um método largamente utilizado pelas empresas e governos para a realização de inventários de GEE.

De acordo com o site institucional do GHG Protocol, "com o objetivo de indicar os diferentes graus de aprofundamento e promover a melhoria contínua no processo de desenvolvimento dos inventários corporativos, o Programa Brasileiro desenvolveu um sistema de qualificação dos inventários, em que estes são classificados como Bronze, Prata ou Ouro" (site GHG Protocol, acesso em 13/01/2016).

O programa define ainda os graus de aprofundamento, listados na íntegra abaixo, como:

Bronze - Participantes que optarem por essa modalidade podem submeter um relatório parcial de GEE de um subgrupo de suas operações, fontes ou gases, contanto que estas informações estejam de acordo com as diretrizes das "Especificações do Programa Brasileiro GHG Protocol” para contabilização, cálculo e publicação do relatório.

Prata - Um inventário de GEE deve fornecer a contabilização por completo de todas as emissões de GEE da organização resultante de fontes localizadas dentro dos limites geográficos estabelecidos pelo Programa e dentro dos limites organizacionais e operacionais da organização participante.

Ouro - Será qualificado como Inventário Ouro àquele que, além de cumprir todos os requisitos para o enquadramento na categoria prata, for verificado por uma terceira parte independente de acordo com as regras do Programa Brasileiro GHG Protocol. A escolha de uma verificadora deve ser feita de forma criteriosa por parte da empresa integrante do Programa. Recomenda-se uma análise do histórico da 
empresa, reconhecimento no mercado e experiência na verificação de inventários corporativos de GEE.

Insta salientar que o programa apresenta novas diretrizes para a verificação independente dos inventários, ainda em desenvolvimento e elaborados com base nas "Especificações do Programa Brasileiro GHG Protocol". Tais diretrizes complementam às "Especificações do Programa Brasileiro GHG Protocol" e objetivam detalhar os requisitos mínimos de verificação independente (site GHG Protocol, acesso em 13/01/2016).

No momento da realização deste estudo, as diretrizes encontravam-se em fase de consulta pública e em breve estarão disponibilizadas no site do GHG, sem, no entanto, constar uma previsão de quando as novas diretrizes estarão finalizadas para que novos inventários possam se adequar.

Segundo as normas do programa, a contabilização, quantificação, elaboração e publicação de inventário de GEE no âmbito do Programa Brasileiro GHG Protocol deve estar em conformidade com os cinco princípios de contabilização de GEE apresentados no GHG Protocol Corporate Standard e na norma ISO14064-1. A finalidade desses princípios é apoiar todos os aspectos relacionados à contabilização e à elaboração de inventários de GEE. São eles:

Relevância

Integralidade

Consistência

Transparência

Exatidão

\section{3.}

\section{PAS 2050}

Com o intuito de avaliar as emissões de gases de efeito estufa do ciclo de vida de bens e serviços, em 2007, a Carbon Trust e a Defra solicitaram à BSI British Standard Institute, uma empresa britânica de normas de negócios, um guia para avaliar a emissão de GEE do ciclo de vida de bens e serviços.

O PAS 2050 oferece às organizações um método para relatar as emissões de GEE decorrentes de suas cadeias de fornecimento, e apresenta como objetivo 
principal fornecer um suporte comum para quantificação das emissões de GEE e carbono equivalente, visando programas que permitam significativa redução dessas emissões.

Em seu escopo, inclui um conjunto de princípios que norteiam o desenvolvimento de requisitos suplementares para a aplicação do PAS 2050 a determinados tipos de produtos.

Ressalta-se aqui a inexistência de uma padronização de técnicas de comunicação destes relatos, e sugere-se às organizações que ao implementar esta ferramenta, disponibilize todas as informações relevantes de apoio das informações descritas.

Por descrever a quantidade de gases de efeito estufa gerada por uma atividade, ou por uma organização, foi cunhado o termo "Pegada de carbono", pela qual tornou-se mundialmente conhecida.

Emissões de GEE da cadeia de suprimentos, que incluem àquelas associadas aos processos não controlados pela própria empresa, podem ser medidas, quer ao nível da empresa ou do nível de um produto individual.

Há benefícios para ambos, companhia e produto, na avaliação de emissões no nível da cadeia de suprimentos, contudo, a PAS 2050 foca-se apenas no nível do produto.

Destaca-se que este guia não avalia outras potenciais aplicações sociais, impactos econômicos e ambientais ou problemas decorrentes do fornecimento de produtos ou questões associadas o ciclo de vida dos produtos, tais como as emissões não-GEE, acidificação, eutrofização, toxicidade, biodiversidade ou normas de trabalho e não fornece um indicador do impacto ambiental geral destes produtos, como pode resultar de outros tipos de avaliação do ciclo de vida.

Para atender aos requisitos estabelecidos, as organizações relatoras devem ser capazes de demonstrar aderência aos cinco princípios propostos. São eles:

Relevância

Integridade

Consistência

Precisão

Transparência 


\section{4 .}

\section{ABNT NBR ISO 26000}

Publicada em 2010, a ISO 26000 surge com o intuito de ser a primeira norma internacional de Responsabilidade Social Empresarial. Com a proposta de servir como um importante direcionador para as corporações e não como uma certificadora.

Os temas centrais do documento abrangem as áreas de Direitos Humanos; Práticas de Trabalho; Meio Ambiente; Práticas Legais de Operação; Combate à Corrupção e Propina; Consumidores e Desenvolvimento aliado à participação comunitária.

É aplicável a todos os tipos e portes de organizações (pequenas, médias e grandes) e de todos os setores (governo, ONG's e empresas privadas), e por não tratar-se de uma norma certificadora, apresenta como característica marcante e divergente das tradicionais normas de certificação da ISO, o caráter livre no formato do relato. No entanto, deve-se observar a aderência aos sete princípios da ISO 26000, que são:

Responsabilidade

Transparência

Comportamento Ético

Consideração pelas partes

interessadas Legalidade

Normas Internacionais

Direitos Humanos 


\section{5.}

\section{ABNT NBR ISO 14065}

O objetivo geral das atividades de validação ou verificação de GEE é dar confiança a todas as partes que dependem de uma declaração de GEE. A parte que faz a afirmação de GEE é responsável pela conformidade com os requisitos do programa GHG. Esta Norma Internacional fornece requisitos para organismos que realizam a validação de GEE ou verificação usando ISO 14064-3 ou outras normas ou especificações pertinentes, ou seja, destina-se aos organismos de validação e de acreditação, estabelecendo os procedimentos a serem utilizados, assim como restrições e responsabilidades dessas entidades.

A norma ISO 14064 visa estabelecer procedimentos para a redução dos GEE, para promover a consistência, transparência e credibilidade da quantificação, monitoramento, relatórios e verificação de GEE; permitir a identificação e gerenciamento de responsabilidades, recursos e riscos relacionados com os GEE; facilitar o comércio de créditos de GEE, seja "Kyoto Compliance" e/ou "Non Kyoto Compliance"; e ainda apoiar projetos, desenvolvimentos e implementações de programas de GEE comparáveis e consistentes.

Ele contém uma série de princípios que essas instituições devem ser capazes de demonstrar e estabelece requisitos específicos que reflitam esses princípios.

Segundo a norma (ISO, 2012), esta fornece aos administradores do programa GHG, uma base para avaliar e reconhecer a competência dos organismos de validação e verificação. Sugere ainda que pode ser aplicada de outras formas, tais como na avaliação de pares dentro de grupos de validação ou de corpos de verificação ou entre esses grupos.

O uso desta norma decorre da aplicação das "normas-base" ISO 14064.1 e ISO 14064.2, conforme ilustra a imagem a seguir. 


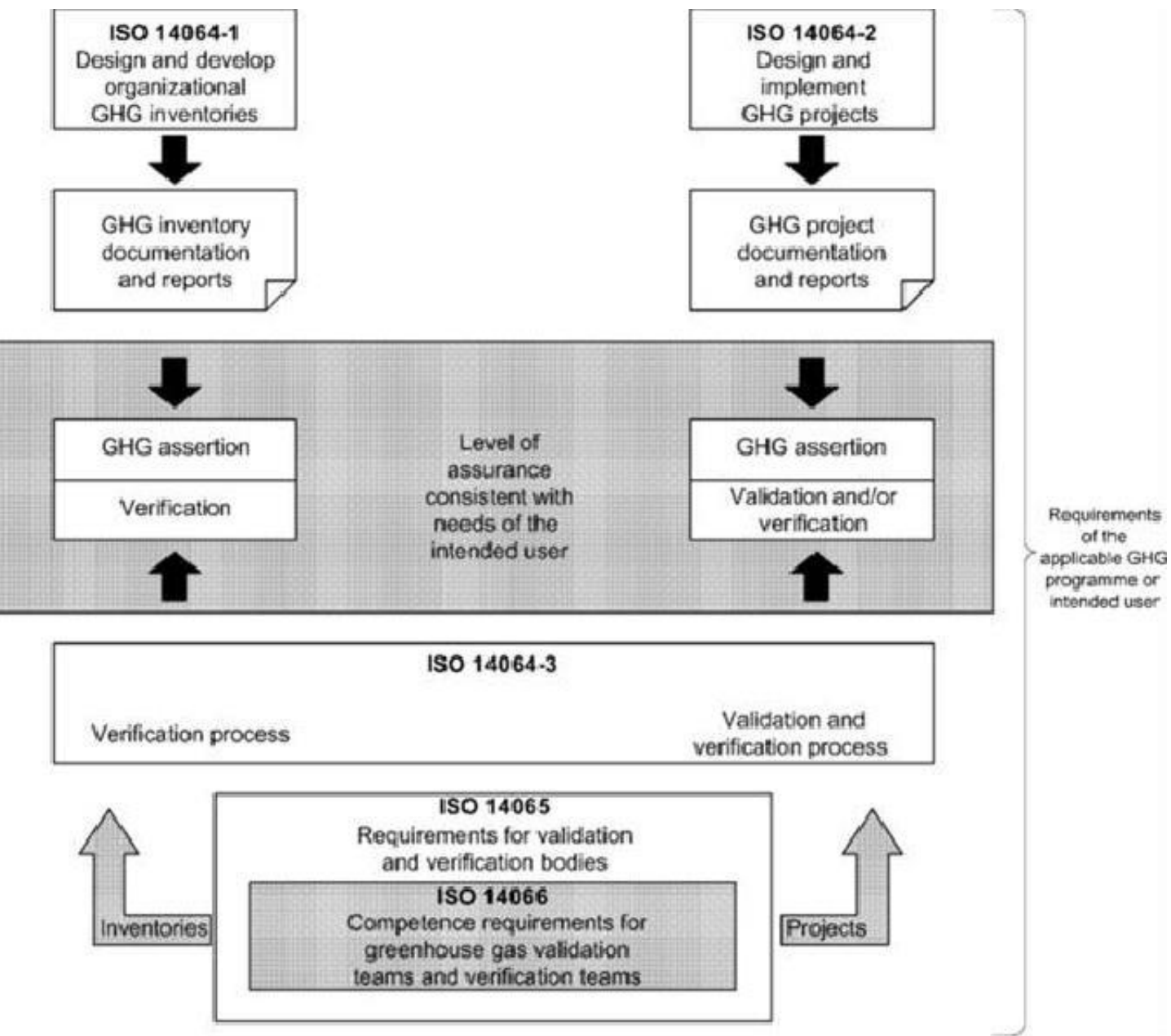

Figura 3.1 - Estrutura para aplicação da ISO 14065 com a norma ISO 14064-1, ISO 14064-2, ISO 14064-3 e ISO 14066

Fonte: ISO 14065

\section{6.}

\section{NORMA SA 8000}

Criada em 1989 pela Social Accountability International (SAI), afiliada ao Conselho de Prioridades Econômicas, é vista como o padrão independente de locais de trabalho mais aceito do mundo.

A norma SA 8000 especifica requisitos de responsabilidade social para possibilitar a empresa: (i) desenvolver, manter e executar políticas e procedimentos com o objetivo de gerenciar aqueles temas os quais ela possa controlar ou influenciar; (ii) demonstrar para as partes interessadas que as políticas, procedimentos e práticas estão em conformidade com os requisitos desta norma;

A abrangência desta norma a coloca como universalmente aplicável em relação à localização geográfica, setor da indústria e tamanho da empresa (SAI 
2001).

Os requisitos de Responsabilidade Social, adotadas pela norma são:

Trabalho infantil

Trabalho forçado

Saúde e segurança

Liberdade de associação e direito à negociação

coletiva Discriminação

Práticas disciplinares

Horário de trabalho

Remuneração

Sistema de gestão

Ressalta-se que além de definir normas de trabalho, a SA 8000 contempla acordos internacionais existentes, incluindo as convenções da Organização Internacional do Trabalho, a Declaração Universal dos Direitos Humanos e a Convenção das Nações Unidas sobre os Direitos da Criança.

Para adotar a certificação SA 8000 a organização deve levar em consideração o impacto social de suas operações, além das condições sob as quais seus funcionários, parceiros e fornecedores trabalham

\section{7.}

\section{Carbon Disclosure Project}

O Carbon Disclosure Project - CDP é uma organização sem fins lucrativos independente que objetiva conduzir ações envolvendo a mitigação dos efeitos de emissões de GEE e uso sustentável da água por empresas e cidades.

O CDP configurou-se como um grande portal acerca das mudanças climáticas e, como principal atribuição, reunir informações para decisões de grandes investidores.

Segundo o CDP, suas informações possibilitam aos signatários acesso a uma fonte global anual de informações que suportam em longo prazo uma análise objetiva do ambiente financeiro.

Neste contexto, configura-se como a principal iniciativa do setor financeiro em relação à mitigação das mudanças climáticas criando uma relação 
entre acionistas e empresas focada em oportunidades de negócio decorrentes do aquecimento global.

A forma de coleta e dados ocorre por meio de um questionário acerca de governança corporativa e não restringindo-se à emissões de GEE. A parte quantitativa do questionário representa uma pequena parcela das perguntas e o questionário trata de questões mais abrangentes além da mensuração das emissões de GEE.

O questionário está dividido nos seguintes itens:

Gestão

Governança

Estratégia

Metas e iniciativas

Riscos e oportunidades

Emissões

Informações relevantes

Dentre os instrumentos tratados neste capítulo, este destaca-se pela possibilidade de os relatos não serem públicos, podendo ser tratados como dados sigilosos, sendo acessados apenas pelos signatários do projeto.

No contexto internacional, diversas entidades, como a Green Research, empresa de pesquisa, assessoria e consultoria com foco em tecnologia limpa, energia alternativa e sustentabilidade, afirma ser a CDP uma entidade em condições de desempenhar importante papel no cenário da sustentabilidade (Green Research, 2009).

Ao pedir às empresas que divulguem suas emissões de gases de efeito estufa, o CDP está implicitamente pedindo às empresas para medirem suas emissões. Dessa forma a Green Research afirma que as empresas podem adquirir o hábito de medir emissões entrando em uma posição para começar a controlá-las e reduzi-las. (Green Research, 2009) 


\section{8.}

\section{Quadro comparativo das normas e guias sobre gestão sustentável das organizações}

No que tange à utilização dos diferentes sistemas de indicadores estudados, percebe-se que, a importância de cada dimensão dentro de cada sistema é inversamente proporcional ao número de dimensões abordadas.

Em outras palavras, quanto menos aspectos abrangidos pelas referencias normativas, maior relevância este mesmo aspecto apresentará dentro do sistema de indicadores, logo uma ferramenta que apresenta em seu escopo um único aspecto, terá menos potencial de respostas às necessidades específicas de CDCEC.

Apresenta-se um quadro comparativo dos referenciais normativos abordados neste capítulo, como uma síntese dos principais aspectos relevantes para este estudo, demonstrando a amplitude da ferramenta quanto a escopo, esfera, agregação dos dados e participação, para melhor compreensão

Quadro 3.2 - Quadro comparativo dos referenciais normativos aplicáveis à CDCEC

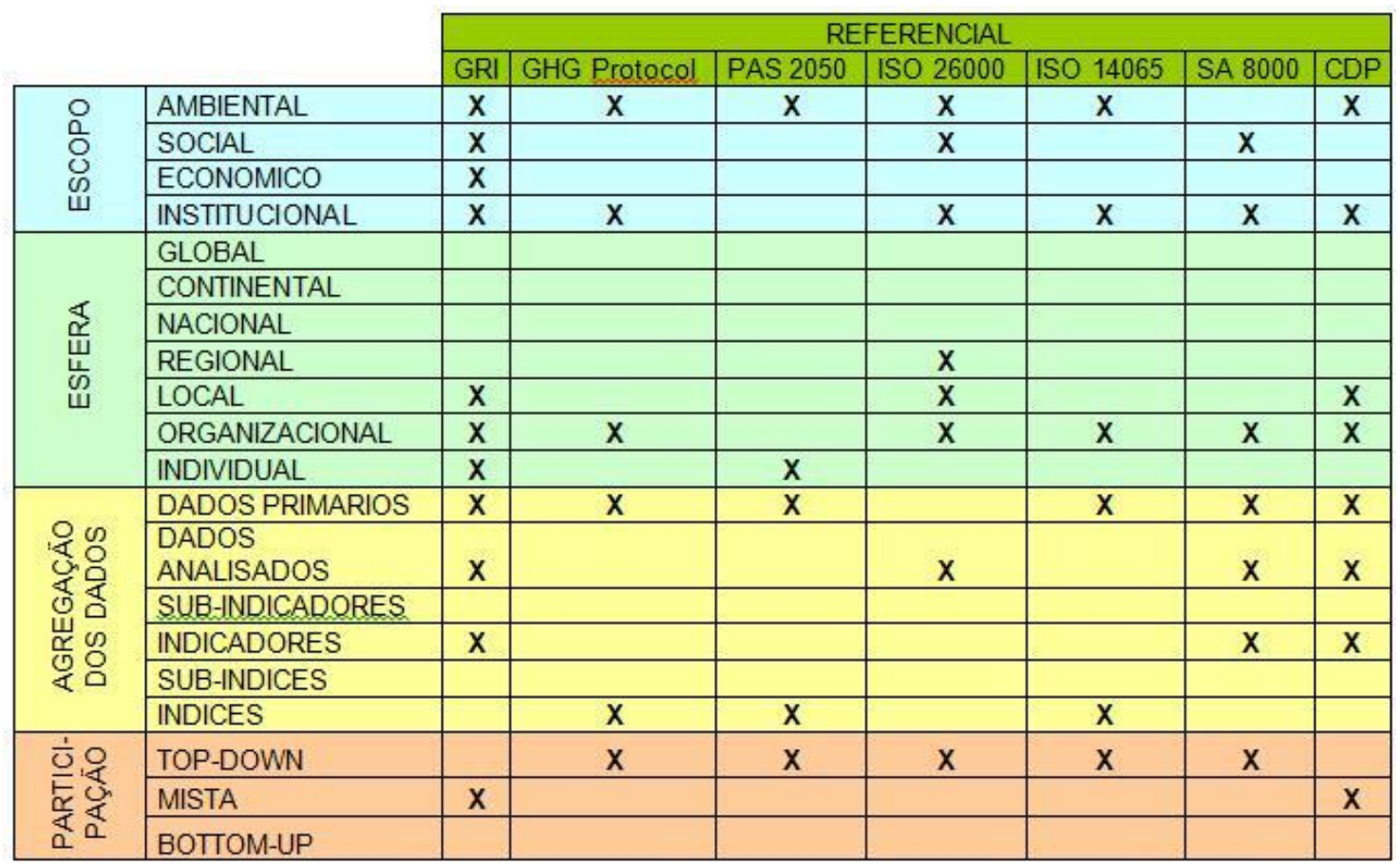

Fonte: Adaptado de Van Bellen, 2002.

As questões referentes ao monitoramento e avaliação de desempenho sustentável requerem sistemas, indicadores inter-relacionados ou a agregação de 
diferentes indicadores de forma interligada. Segundo Van Bellen (2002) existem poucos sistemas de indicadores que lidam especificamente com 0 desenvolvimento sustentável, sendo em sua maioria em caráter experimental, e estes sistemas foram desenvolvidos com o propósito de melhor compreender os fenômenos relacionados à sustentabilidade.

Para Gallopin (1996), os "indicadores de sustentabilidade podem ser considerados os principais componentes da avaliação do progresso em relação a um possível desenvolvimento sustentável". Sugere ainda, esse autor, que a utilização de indicadores de sustentabilidade deve ocorrer em função da disponibilidade dos mesmos e do custo de sua obtenção.

Insta-se necessário adotar um padrão de medição, amplo o suficiente para abarcar diferentes aspectos intimamente relacionados com a sustentabilidade e RS, a exemplo dos aspectos ecológicos, econômico-financeiros, socioculturais e institucionais.

\section{9.}

\section{Implicações para o desempenho sustentável de CDCEC}

Tem sido demonstrado que os CDCEC bem geridos desempenham um importante papel na economia bem como nas estratégias de desenvolvimento das regiões urbanas. A qualidade dos produtos e serviços ofertados por CDCEC, influenciam diretamente o desenvolvimento cultural de uma região.

No entanto, percebe-se que não existe um modelo que sirva de guia ou referencial normativo de avaliação de desempenho sustentável aplicável a tais instituições, bem como não existe nenhum modelo que permita comparar o desempenho e assim escalonar um ranking entre estas instituições com o objetivo de motivar outros gestores na aplicação de metodologias que permitam alcançar desempenhos satisfatórios segundo as definições pré-estabelecidas acerca de desenvolvimento sustentável e responsabilidade social.

Percebe-se ainda que diferentes guias e normativos podem subsidiar um modelo padrão a ser aplicado em CDCEC e assim preencher a lacuna não observada em nenhum modelo ou guia para setores específicos, como encontrados para setores como petróleo e gás, energia, construção civil entre outros.

Diferentes sistemas de indicadores de desempenho sustentável tornaram- 
se mundialmente aceitos e reconhecidos, e dentre os que são aplicáveis aos CDCEC, destaca-se o GRI, pela abrangência de seu escopo, esfera de aplicação e agregação dos dados, e por ainda apresentar liberdade quanto à forma de comunicação dos resultados para os stakeholders das organizações que o adotam. 


\section{4 \\ Quadro lógico para construção de indicadores e métricas de desempenho para CDCEC sustentável}

Este capítulo compreende a elaboração do quadro lógico da ação objeto da avaliação de desempenho; diversas taxonomias de indicadores e métodos adotados na definição e seleção de métricas, que de fato expressem os resultados esperados de intervenções. Alguns estudiosos da avaliação neste capítulo citados, afirmam que aferir a qualidade da teoria significa, em síntese, verificar se o programa está bem desenhado e se apresenta um plano plausível para o alcance dos resultados esperados e destacam ainda a importância de se partir da análise da teoria do programa para a identificação de deficiências do desenho que poderão interferir no seu desempenho.

\section{1. \\ Elaboração do quadro lógico}

Concebida pelo Instituto de Pesquisa Econômica Aplicada (Ipea), com o objetivo de organizar avaliações do Plano Plurianual (PPA) com foco em seus resultados, o quadro lógico de um programa busca configurar um desenho de seu funcionamento, que possa ser realizado em determinadas circunstâncias, para resolver os problemas identificados.

Os elementos do quadro lógico incluem recursos, ações, produtos, resultados intermediários e finais, assim como as hipóteses que suportam essas relações e as influências das variáveis relevantes do contexto do programa ou regulamentação (Ferreira, Cassiolato e Gonzalez, 2009; Cassiolato e Gueresi, 2010).

Segundo Ferreira, Cassiolato e Gonzalez, (2009) e Cassiolato e Gueresi (2010), um modelo lógico deve nortear a estratégia de execução de um determinado programa e a definição dos indicadores para o monitoramento e avaliação de seu desempenho.

Neste contexto, para a elaboração de um modelo lógico, os autores 
propõem três componentes: explicação do problema e referências básicas do programa (objetivos, público-alvo e beneficiários); estruturação do programa para alcance de resultados (resultados finais e impactos) e identificação de fatores relevantes do contexto, que são variáveis relevantes que se encontram fora da governabilidade dos responsáveis pela implementação do programa.

Desta forma, a elaboração do quadro lógico deve corroborar para o atingimento das seguintes premissas:

Definição clara e plausível dos objetivos e resultados esperados do programa;

Identificação de indicadores relevantes de desempenho, que possam ser obtidos a um custo razoável;

Comprometimento dos gestores do programa com o que está proposto no modelo lógico.

O 'contexto organizacional' pode ser percebido como externo e interno. O 'contexto externo' refere-se ao ambiente social, político, econômico e competitivo no qual a instituição está inserida e sobre a qual, a mesma não detém poder de decisão ou influência direta, bem como à percepção, ação e interpretação das políticas e eventos do ambiente externo, como por exemplo os impactos oriundos de uma alteração legal acerca das atividades da organização.

O 'contexto interno' relaciona-se com a estratégia, estrutura, cultura organizacional e com o contexto político existente na própria organização, do qual emerge a motivação para a mudança para o modo sustentável (Pettigrew, 1987, 1992)

É com base neste contexto, que os direcionadores estratégicos são desenvolvidos e, ainda que o ambiente seja restritivo, a instituição ainda tem condições de selecionar quais estratégias serão adotadas, desde que haja um controle adequado e uma seleção dos meios com que os resultados almejados devam ser atingidos.

Essa visão enfatiza o papel da escolha estratégica (Friend e Jessop, 1969), ao considerar que as empresas são capazes não só de captar as mudanças ambientais e adaptarem-se a elas, como também de realizar escolhas entre os tipos de ambiente nos quais desejam operar, adaptando-se a esse contexto. 
Para fins deste estudo, o enfoque será na área em destaque da Fig. 5 acima, onde insere-se a necessidade de elaboração de um arcabouço de indicadores e métricas de desempenho sustentável.

A partir do quadro lógico proposto, torna-se possível definir tais indicadores para a avaliação do desempenho de cada etapa de sua execução. Segundo o Ipea, deve-se desenvolver uma matriz lógica de indicadores, como ilustrado no Quadro 4.1 abaixo.

Quadro 4.1 - Esquema básico da matriz lógica de indicadores de desempenho de um programa

\begin{tabular}{c|c|r|r|r}
\hline Descrição & Metas & $\begin{array}{r}\text { I } \\
\text { ndicadores }\end{array}$ & $\begin{array}{r}\text { Meios de } \\
\text { verificação (fontes) }\end{array}$ & $\begin{array}{c}\text { Pre } \\
\text { missas (fatores } \\
\text { de risco) }\end{array}$ \\
\hline Objetivo & $\begin{array}{c}\text { Metas de } \\
\text { impacto }\end{array}$ & & & \\
\hline $\begin{array}{c}\text { Objetivos de } \\
\text { específicos }\end{array}$ & $\begin{array}{c}\text { Metas detas de } \\
\text { efetividade }\end{array}$ & & & \\
Resultados & $\begin{array}{c}\text { Metas diatos } \\
\text { desempenho }\end{array}$ & & & \\
\hline Atividades & $\begin{array}{c}\text { Metas } \\
\text { operacionais }\end{array}$ & & & \\
\hline
\end{tabular}

Fonte: Cassiolato e Gueresi, 2010.

\section{2.}

\section{Conceituação e função básica dos indicadores}

Encontram-se na literatura especializada de monitoramento e avaliação, diversas definições acerca de indicadores e métricas. No entanto, observa-se que de forma geral, elas se apresentam bastante próximas conceitualmente. De acordo com Ferreira, Cassiolato e Gonzalez (2009):

"O indicador é uma medida, de ordem quantitativa ou qualitativa, dotada de significado particular e utilizada para organizar e captar as informações relevantes dos elementos que compõem o objeto da observação. É um recurso metodológico que informa empiricamente sobre a evolução do aspecto observado".

Segundo Hammond (1995), com suas raízes no latim indicare, que significa descobrir, apontar, anunciar, estimar, os indicadores podem, e devem, comunicar ou informar acerca do progresso em direção a um objetivo, como por exemplo o desenvol vimento sustentável, entretanto, podem também serem entendidos como um recurso que torna mais compreensível uma tendência ou fenômeno, que não seja facilmente detectável (Hammond, 1995).

Pode-se encontrar diversas e diferentes definições acerca do que é um 
indicador. No entanto, entende-se que um indicador pode ser quantitativo e qualitativo, não sendo restrito a apenas uma dessas classificações. Não trata-se apenas uma estatística pois representa uma variável que assume um valor em um tempo específico. Por sua vez, Quiroga defende que "uma variável é uma representação de um atributo de um determinado sistema, incluindo qualidade, característica e propriedade" (Quiroga, 2001). Em uma visão mais abrangente, um indicador é um sinal que aponta uma determinada condição (Gallopín, 1996), com a finalidade de comunicar informações e de auxiliar na tomada de decisões. Finalmente, o objetivo de um indicador é apontar a existência de riscos, potencialidades e tendências no desenvolvimento de um determinado território para que, em conjunto com a comunidade, decisões possam ser tomadas de forma mais racional (Tunstall, 1994; Guimarães, 1998).

Para Gallopin (1996), “os indicadores mais desejados são aqueles que resumam ou simplifiquem as informações relevantes, façam com que certos fenômenos que ocorrem na realidade se tornem mais aparentes; aspecto esse que é particularmente importante na gestão ambiental". Especificamente nessa área, fazse necessário a quantificação, mensuração e comunicação das ações relevantes.

Segundo o Guia referencial para medição de desempenho e manual para construção de indicadores (Brasil 2009), a mensuração é parte essencial de um modelo de gestão de desempenho. No entanto, não pode-se afirmar que é apenas a ação que apura, em sentido estrito, valores ou medidas dos esforços e resultados, por meio de indicadores.

Um sistema de mensuração deve ir além da geração de indicadores e permitir a geração destes em diferentes dimensões de esforços e resultados, balizados por diferentes pesos entre si, haja vista que apresentam medidas de distintas importâncias.

Trata-se, assim, de uma mensuração agregada e ponderada que permitirá a geração de uma medida síntese de desempenho. 


\section{3.}

\section{Construção de indicadores}

Como resultado da Conferência das Nações Unidas sobre o Meio Ambiente, de 1992, o relatório de Brundtland sugere a necessidade de desenvolvimento de novas ferramentas de mensuração e avaliação da sustentabilidade de modo amplo. Como resposta, em 1996, diversos pesquisadores e especialistas em avaliação, se reuniram com o intuito de revisar as iniciativas resultantes da conferência e buscaram sintetizar a percepção acerca dos principais aspectos ligados à avaliação de desenvolvimento sustentável. Este resultado tornou-se conhecido como princípios de Bellágio.

Segundo Hardi e Zdan (1997), tais princípios servem como guia para avaliação de um processo, desde a escolha e o projeto de indicadores, a sua interpretação, até a comunicação de resultados. Os princípios, segundo estes autores, estão inter-relacionados e devem ser aplicados também conjuntamente, sendo que sua aplicação é importante como orientação para a melhoria dos processos de avaliação.

Van Bellen (2004) sugere que, a despeito da existência de variados sistemas relacionados à avaliação da sustentabilidade, persistem diversos elementos que não estão estudados e desenvolvidos devidamente. Como exemplos destes, Van Bellen (2004) destaca: a multidimensionalidade do conceito de desenvolvimento sustentável, a complexidade que decorre da agregação de variáveis que não são diretamente relacionadas, a questão da transparência em sistemas de avaliação, a existência dos julgamentos de valor e sua ponderação nos diversos sistemas, o tipo de processo decisório envolvido, bem como o tipo de variável envolvida (qualitativa, quantitativa ou as duas), entre outros.

Para a eficiente elaboração de um modelo de mensuração, capaz de traduzir o desempenho de uma instituição, insta-se rearranjar os variados sistemas, para que os usuários desses possam selecionar e trabalhar com os modelos que estejam mais alinhados com seus objetivos fins. Busca-se neste estudo elaborar um conjunto de indicadores que permitam aos gestores de CDCEC avaliar a estratégia a partir do desempenho sustentável, subsidiando a tomada de decisão.

Com este objetivo, observou-se os critérios propostos pelo documento intitulado "Indicadores de programas: Guia Metodológico" (Brasil, 2010), e 
apresentado no quadro abaixo.

Quadro 4.2 - Exemplos de critérios para seleção de indicadores

\begin{tabular}{|l|}
\hline Critérios para seleção de indicadores \\
Atendimento às necessidades de informação dos \\
\hline Confiabilidade da fonte \\
\hline Confiabilidade metodológica \\
\hline Desagregabilidade sociodemográfica \\
\hline Desagregabilidade espacial \\
\hline Disponibilidade quando necessário \\
\hline Economicidade de obtenção \\
\hline Estabilidade ao longo do tempo \\
\hline Existência de suporte técnico \\
\hline Facilidade de obtenção \\
\hline Mensurabilidade \\
\hline Objetividade \\
\hline Rastreabilidade ao logo do tempo \\
\hline Representatividade (em relação ao objetivo do programa) \\
\hline Sensibilidade à intervenção \\
\hline Simplicidade de construção e entendimento \\
\hline Tempestividade \\
\hline
\end{tabular}

Fonte: Brasil, 2010, p. 54.

Tais critérios se pressupõem genéricos e aplicáveis a quaisquer realidades. Logo, entende-se ser possível definir outros critérios específicos, que sejam úteis ao conceito empírico a ser medido.

Foram analisados, no capítulo 3 , diversos referenciais normativos de avaliação de desempenho sustentável aplicáveis à CDCEC. Apresenta-se abaixo um quadro ilustrando as categorias e os itens analisados, que embasaram a escolha dos insumos para que se definisse o escopo do modelo de gestão sustentável e seus mecanismos de monitoramento e avaliação, com o arcabouço de indicadores e métricas de desempenho sustentável. 
Quadro 4.3 - Exemplos de critérios para seleção de indicadores

\begin{tabular}{|c|c|}
\hline Categoria & Itens analisados \\
\hline Escopo & Sustentabilidade ambiental, econômica, social e institucional \\
\hline Esfera & Informações já disponibilizadas pelo IBGE e por outras instituições. \\
\hline Dados & $\begin{array}{l}\text { Qualitativos e Quantitativos } \\
\text { Nível de agregação: indicadores e subindicadores. }\end{array}$ \\
\hline Participação & Top-down (especialistas) \\
\hline Interface & $\begin{array}{l}\text { - Complexidade dos cálculos: média complexidade } \\
\text { de decisões Seção II. Conservação e gestão dos recursos para o desenvolvimento) e } 40 \\
\text { (Informação para a adoção de decisões) da Agenda } 21 \text {. } \\
\text { - Abertura: apresentação de indicadores e subindicadores } \\
\text { - Potencial educativo: Para uso e conhecimento de toda comunidade, podendo ser utilizado } \\
\text { para efeitos de comparação com outras nações. } \\
\text { Ainda sim o IBGE dispõe de numerosas informações estatísticas, que permitiriam a } \\
\text { construção de muitos indicadores relevantes e ampliariam as possibilidades de avaliação } \\
\text { do desenvolvimento sustentável e como ponto fraco tem-se Limitação da classificação } \\
\text { urbana/rural da PNAD }\end{array}$ \\
\hline
\end{tabular}

Fonte: Adaptado de Van Bellen, 2002.

O Quadro 4.4 mostra um exemplo didático de "Matriz de avaliação quantitativa de indicadores", na qual foram definidos três critérios eliminatórios indicador.

Quadro 4.4 - Exemplo didático de uma matriz de avaliação quantitativa de indicadores

\begin{tabular}{|c|c|c|c|c|c|c|c|c|c|c|c|c|c|c|}
\hline \multicolumn{15}{|c|}{ Matriz de Avaliação de Indicadores } \\
\hline \multirow[b]{3}{*}{ Indicador } & \multirow{3}{*}{$\begin{array}{l}\text { Interessa } \\
\text { do }\end{array}$} & \multirow{2}{*}{\multicolumn{3}{|c|}{ Tipo de indicador }} & \multicolumn{9}{|c|}{ Natureza do indicador } & \multirow{3}{*}{ Total } \\
\hline & & & & & \multicolumn{3}{|c|}{ Eliminatórios } & \multicolumn{6}{|c|}{ Classificatórios } & \\
\hline & & $\begin{array}{l}\text { Cha } \\
\text { ve }\end{array}$ & $\begin{array}{c}\text { Complement } \\
\text { ar }\end{array}$ & $\begin{array}{c}\text { Especifi } \\
\text { co }\end{array}$ & $\begin{array}{l}0 \\
1\end{array}$ & $\begin{array}{l}c \\
2 \\
\end{array}$ & $\begin{array}{l}c \\
3\end{array}$ & $\begin{array}{l} \\
4 \\
\end{array}$ & $\begin{array}{c}\mathrm{Pe} \\
\text { so } \\
\text { (C4) }\end{array}$ & $\begin{array}{l}c \\
5 \\
\end{array}$ & \begin{tabular}{|r|} 
Pe \\
so \\
(C5) \\
\end{tabular} & $\begin{array}{l}c \\
6 \\
\end{array}$ & $\begin{array}{c}\mathrm{Pe} \\
50 \\
\text { (C6) }\end{array}$ & \\
\hline $\begin{array}{l}\text { Indicador } \\
\text { candidato } 1 \text {. }\end{array}$ & & $\mathrm{x}$ & & $\mathrm{x}$ & 1 & 1 & 1 & 2 & 9 & 2 & 3 & 2 & 1 & 26 \\
\hline $\begin{array}{l}\text { Indicador } \\
\text { candidato } 10\end{array}$ & & & X & & 1 & 1 & 1 & 1 & 9. & 2 & 3 & Q & 1 & 15 \\
\hline $\begin{array}{l}\text { Indicador } \\
\text { candidato } 3\end{array}$ & & & $\mathrm{x}$ & & 1 & 1 & 1 & 1 & 2 & Q & 3 & Q & 1 & 9 \\
\hline $\begin{array}{l}\text { Indicador } \\
\text { candidato } 4\end{array}$ & & & $\mathrm{x}$ & & 1 & 1 & 1 & Q & 2 & 2 & 3 & 2. & 1 & \& \\
\hline $\begin{array}{l}\text { Indicador } \\
\text { candidato } 6 \text {. }\end{array}$ & & & $x$ & $x$ & 1 & 1 & 1 & Q & 2 & 2 & 3. & Q & 1 & 6 \\
\hline $\begin{array}{l}\text { Indicador } \\
\text { candidato \& }\end{array}$ & & $x$ & & & 1 & 1 & 1. & Q & 2 & Q & 3 & 1 & 1 & 1 \\
\hline $\begin{array}{l}\text { Indicador } \\
\text { candidato } 2\end{array}$ & & & $\mathrm{x}$ & & 1 & $Q$ & 1 & 1 & 2. & 1 & 3 & 1 & 1 & Q \\
\hline $\begin{array}{l}\text { Indicador } \\
\text { candidato } 5 .\end{array}$ & & & $\mathrm{x}$ & & 1 & 1 & Q & Q & 2 & 1 & 3 & 1 & 1 & Q \\
\hline $\begin{array}{l}\text { Indicador } \\
\text { candidato Z }\end{array}$ & & & & $\mathrm{x}$ & 1 & Q & 1 & 1 & 2 & 1 & 3 & 1 & 1 & Q \\
\hline $\begin{array}{l}\text { Indicador } \\
\text { candidato } 2\end{array}$ & & & $\mathrm{x}$ & & 1 & $Q$ & 1 & 1 & 2 & 1 & 3. & Q & 1 & Q \\
\hline \multicolumn{15}{|c|}{ Critérios } \\
\hline$c_{1}$ & \multicolumn{14}{|c|}{ Proximidade com o objetivo do Programa } \\
\hline $\mathrm{C} 2$ & \multicolumn{14}{|c|}{ Atendimento às necessidades de informaçăo dos interessados } \\
\hline $\mathrm{C} 3$ & \multicolumn{14}{|c|}{ Aderência à escala espacial desejada } \\
\hline $\mathrm{C4}$ & \multicolumn{14}{|c|}{ Aderència à escala temporal desejada } \\
\hline $\mathrm{C5}$ & \multicolumn{14}{|c|}{ Validade ou representatividade em relaçăo ao conceito } \\
\hline C6 & \multicolumn{14}{|l|}{ Confiabilidade } \\
\hline
\end{tabular}

Fonte: Brasil, 2010 
Essa ferramenta permite que os indicadores sejam organizados em forma de um ranking em ordem decrescente de pontos obtidos, de acordo com o atendimento aos critérios pré-definidos (de $\mathrm{C} 1$ a C6).

\section{4. \\ Implicações para a construção de indicadores e métricas de desempenho para CDCEC sustentável}

Indicadores de desempenho são ferramentas essenciais de gestão para se realizar a medição e aferir o conseqüente nível de desempenho e sucesso de uma organização ou de um determinado processo, ou ainda são formas quantificáveis de se representar características de produtos e processos.

No caso específico de CDCEC, como refletido no capítulo 2.4, as experiências internacionais demonstram estes indicadores, precisam atender ao escopo da sustentabilidade tríplice e sua forma de comunicação clara e de fácil compreensão, não se limitando apenas à um aspecto da sustentabilidade, nem em características específicas de uma determinada região.

Toda ação organizacional deve ser monitorada para que possa ser avaliada a eficácia da ação ou processo. Os indicadores permitem avaliar resultados positivos e negativos, lastrear uma decisão, verificar posição em relação às metas, melhorar processos, medir desempenho, dentre outras funções e existem diferentes categorias de indicadores, que podem ser, por exemplo, indicadores quantitativos, qualitativos, direcionais e outros. Devem ser bem definidos, acompanhados sistematicamente para tomada de decisão e aplicáveis ao que de fato for relevante.

Os indicadores são formas quantificáveis de se representar características de produtos e processos. Os efeitos das ações devem ser medidos de alguma forma, para que o gerenciamento de um programa ou ação governamental seja realizado de forma eficiente e eficaz. Os indicadores permitem avaliar resultados positivos e negativos, servir de base para uma decisão, verificar posição em relação às metas, melhorar processos, medir desempenho, dentre várias outras funções que poderiam ser aqui citadas. Para serem utilizados da melhor maneira possível, os indicadores devem ser bem definidos, acompanhados sistematicamente para tomada de decisão e aplicáveis ao que de fato for relevante. 


\section{5 \\ Indicadores e métricas de desempenho para CDCEC sustentável: estudo de caso da FPCRJ}

A partir dos resultados da revisão bibliográfica e documental que nortearam a definição dos objetivos da pesquisa e a escolha das ferramentas de avaliação mais adequadas para o contexto da Fundação Planetário da Cidade do Rio de Janeiro, iniciou-se a fase da pesquisa aplicada propriamente dita.

Apresenta-se, neste capítulo, o estudo de caso da FPCRJ, focalizando-se os resultados da pesquisa de campo realizada junto aos gestores e especialistas dessa instituição, com o apoio direto da Presidência e Assessoria Técnica.

O desenvolvimento do estudo de caso, conforme protocolo de Yin (2005), compreendeu sete etapas, a saber: (i) definição das questões do estudo de caso; (ii) seleção do tipo de estudo; (iii) delimitação e caracterização da unidade de análise e seu contexto organizacional; (iv) elaboração da ferramenta para a pesquisa de campo (roteiro para as entrevistas e formulários para o diagnóstico); (v) coleta, formatação e análise dos dados; (vi) descrição dos resultados, com proposições de modificações em métodos tradicionais ou desenvolvimento / adoção de novos métodos analíticos; e (vii) elaboração das conclusões do estudo de caso.

\section{1 .}

\section{Questões e proposições do caso}

A questão principal deste estudo é propor indicadores e métricas para a gestão sustentável de Centros de Difusão de Ciência, Educação e Cultura, tomando-se como espaço de aplicação a Fundação Planetário da Cidade do Rio de Janeiro, segundo abordagem conceitual que integra ferramentas de avaliação adaptadas e adotadas nesse campo e referenciais normativos consagrados em nível internacional. Essa abordagem é apresentada no capítulo 3.

Pretende-se, com os resultados deste estudo de caso responder duas das quatro questões específicas da pesquisa, a saber: 
Identificar e analisar referenciais normativos de sustentabilidade, tendo em vista a escolha de indicadores e métricas aplicáveis a Centros de Difusão de Ciência, Educação e Cultura.

Desenvolver sistemática de avaliação de desempenho sustentável para Centros de Difusão de Ciência, Educação e Cultura e aplicar na Fundação Planetário da Cidade do Rio de Janeiro como estudo de caso.

\section{2.}

\section{Tipo de caso: por que estudo de caso único holístico?}

Apresentam-se, na Figura 5.1, os quatro tipos de estudos de casos, conforme a classificação apresentada por Yin (2005). Destacam-se os projetos de caso único, com indicação da unidade de análise do presente estudo de caso e seu contexto organizacional.

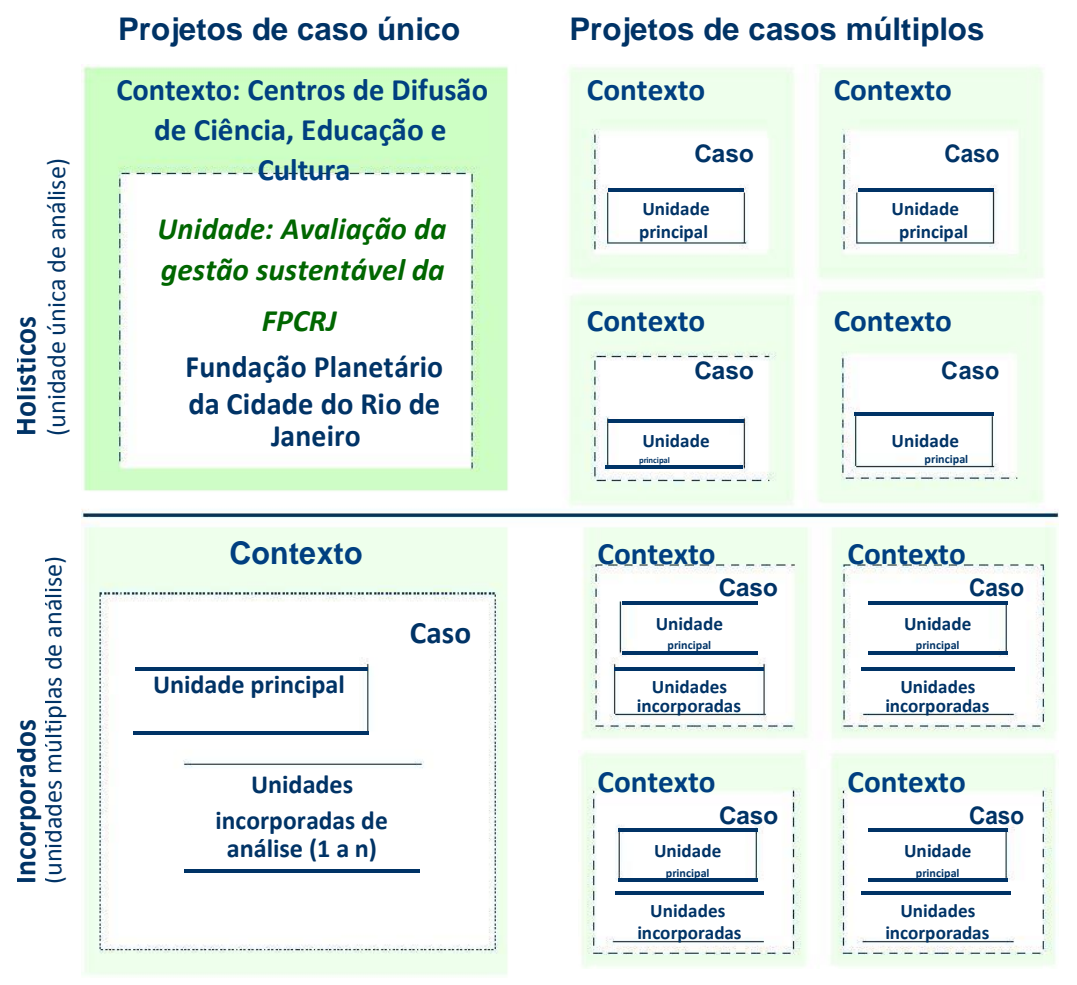

Figura 5.1 - Seleção do tipo do estudo de caso Fonte: Adaptado de Yin (2005, p. 61).

Yin (2005) sugere que eles representam a estratégia preferida de pesquisa, em situações que as questões são do tipo 'como' e 'porque' e quando o pesquisador tem pouco controle sobre os fatos ou ainda quando o foco se encontra em fenômenos contemporâneos inseridos em algum contexto da vida real. 
Inserem-se neste contexto ainda seis fontes de evidências, propostas por Yin (2005) no sentido de se obter um bom estudo de caso. São elas: (i) documentação; (ii) registro em arquivos; (iii) entrevistas; (iv) observações diretas; (v) observações participantes; e (vi) artefatos físicos.

Neste estudo de caso, utilizou-se o maior número possível dessas fontes de evidências, dentro do universo de documentos e registros disponibilizados, uma vez que Yin (2005) recomenda: "quanto mais fontes forem utilizadas, melhor para a qualidade do estudo de caso".

O tipo de caso selecionado foi o estudo de caso único holístico, considerando-se:

- um único contexto organizacional - a Fundação Planetário da Cidade do Rio de Janeiro;

- uma unidade de análise - a avaliação da Gestão sustentável da FPCRJ;

- a contribuição da FPCRJ para a estratégia de sustentabilidade corporativa de outros centros congêneres, na perspectiva de ser um modelo passível de aplicação nestas instituições.

\section{3.}

\section{Unidade de análise e seu contexto}

A unidade de análise deve considerar o modo como o problema de pesquisa foi definido. Dessa forma, analisando-se o problema de pesquisa, definiu-se que a unidade de análise é a avaliação da gestão sustentável da Fundação Planetário da Cidade do Rio de Janeiro, segundo abordagem conceitual que integra ferramentas de avaliação adotadas nesse campo e referenciais normativos consagrados em nível internacional. A seguir, apresenta-se de forma resumida o perfil institucional da FPCRJ e seu contexto organizacional. Busca-se evidenciar o alinhamento do desenvolvimento de novas métricas de desempenho sustentável e da substituição de métodos até então adotados e expostos no PE 2009 -2012.

\subsection{1.}

\section{Fundação Planetário da Cidade do Rio de Janeiro}

Com o objetivo de difundir a Astronomia, as ciências afins e desenvolver projetos culturais, a Fundação Planetário conta com diversas atividades, como 
sessões de cúpula, experimentos interativos, observações ao telescópio, cursos, palestras e exposições (Relatório de Gestão 2014).

A instituição conta com duas cúpulas de projeção em atividade, a saber: a Carl Sagan, com capacidade para atender 263 pessoas por sessão e a Galileu Galilei, que pode atender até 93 pessoas por sessão e conta com um moderno sistema de imersão digital.

Ambos os planetários apresentam condições tecnológicas para reproduzir, em condições fidedignas, o céu visto da Terra a olho nu em qualquer latitude ou época do ano. Seu principal público alvo, escolas públicas e particulares, são atendidos durante a semana com agendamento prévio, e nos fins de semana e feriados, as sessões são abertas ao público em geral.

A FPCRJ, segundo seu relatório de atividades, realiza ainda atividades como observações do céu, gratuitamente, na Praça dos Telescópios. Esta área, com capacidade para localizar automaticamente cerca de 64 mil objetos, possui quatro equipamentos modernos, instalados em cúpulas.

Fundada em 19 de novembro de 1970, a instituição possui uma área total de 16 mil metros quadrados sendo 12 mil metros quadrados de área construída. Destaca-se dentre seus espaços, uma biblioteca com acervo de aproximadamente 2,5 mil livros e vários vídeos educativos, especializados em Astronomia, Astronáutica, Astrofísica e Física. Abriga ainda um teatro (sob a responsabilidade da Rede Municipal de Teatros), e auditórios, restaurantes, estacionamento além de uma ampla área verde destinada à recreação das crianças. Em seu site, pode-se realizar uma visita em terceira dimensão ao Museu do Universo - Experimentos Interativos - composto por 60 experimentos, com os quais o público pode interagir, fisicamente ou online e aprender um pouco mais sobre Astronomia. Ressalta-se que o conteúdo destes experimentos foi desenvolvido pela equipe técnica da instituição, que se preocupou em criar um arrojado design de ambientação a partir de uma idéia inovadora.

A FPCRJ possui como missão "difundir a Astronomia e as Ciências Afins, integrando ciência, educação e cultura de forma inovadora em um ambiente acolhedor na Cidade do Rio de Janeiro" e como visão - Ser agente de transformação social por meio da difusão da Astronomia e Ciências Afins, da 
educação complementar e da cultura, buscando permanente inovação e sustentabilidade:

- Atender todos os alunos da Rede Municipal de Ensino.

- Estar entre as maiores instituições congêneres em números de atendimentos.

- Estar na vanguarda do conhecimento na difusão da Astronomia e Ciências Afins.

- Estar entre os Centros de Difusão de Ciência, Educação Complementar e Cultura mais sustentáveis do mundo.

Apresenta ainda como valores e pilares de sua existência:

- Inovação

- Excelência

- Equidade social

- Universalização do acesso

- Transversalidade

- Valorização do capital humano

- Colaboração

- Sustentabilidade

Assim a FPCRJ como uma instituição que tem propósitos de desenvolver atividades de pesquisa, educação e de proporcionar o lazer, com viés cultural, educativo e de pesquisa no âmbito da educação formal, não formal e informal, oferecer ao cidadão uma alternativa de qualidade. Além disso, a Fundação se preocupa em deixar bem estruturadas todas as suas diretrizes e visões em relação ao ambiente em que se insere.

Para melhor informações adicionais, encontram-se anexo a este trabalho o organograma da instituição. 


\section{4 .}

\section{Instrumentos de pesquisa}

Segundo Duarte (2002) "a definição do objeto de pesquisa assim como a opção metodológica constituem um processo tão importante para o pesquisador quanto ao texto que se elabora no final". Afirma ainda que as conclusões de um estudo são possíveis devido aos instrumentos utilizados na coleta de dados e a interpretação dos resultados obtidos.

A escolha dos instrumentos de pesquisa deve ser realizada de forma a se adequar de modo apropriado em relação ao estudo com o intuito de identificar quais os possíveis fatores positivos e negativos inerentes ao instrumento de pesquisa a ser utilizado e quais as implicações no resultado final.

Para fins deste estudo, os instrumentos de pesquisa adotados foram observação direta e entrevistas.

\subsection{1.}

\section{Observação}

Gil (1999) destaca que na observação os fatos são percebidos de forma direta, sem que haja qualquer tipo de intermediação, sendo considerada uma vantagem, em comparação aos demais instrumentos.

Marconi e Lakatos (2003) definem observação como "uma técnica de coleta de dados para conseguir informações e utiliza os sentidos na obtenção de determinados aspectos da realidade. Não consiste apenas em ver e ouvir, mas também em examinar fatos ou fenômenos que se desejam estudar".

Ainda segundo Gil (1999) e Marconi e Lakatos (2003) a observação apresenta as seguintes vantagens e limitações:

Vantagens - possibilita meios para estudar uma ampla variedade de fenômenos em um ambiente complexo; propicia a coleta de dados sobre um conjunto de atitudes comportamentais; permite obter dados não contemplados em questionários e entrevistas.

Limitações - a presença do pesquisador pode provocar alterações no comportamento dos observados; os acontecimentos podem ocorrer simultaneamente, dificultando a coleta dos dados; algumas informações podem não estar acessíveis ao pesquisador. 
Neste trabalho, foram realizadas cerca de 30 horas de observação em dias variados a fim de entender a rotina e a reação dos usuários/clientes/públicosob cada aspecto estudado.

\subsection{2.}

\section{Entrevista}

Gil (1999) define entrevista como "uma forma de interação social. Mais especificamente, é uma forma de diálogo assimétrico, em que uma das partes busca coletar dados e a outra se apresenta como fonte de informação".

Para Marconi e Lakatos (2003) as vantagens e limitações da entrevista baseiam-se em:

Vantagens - oferece flexibilidade, pois o entrevistador pode esclarecer o significado das perguntas e adaptar-se mais facilmente às pessoas e às circunstâncias em que se desenvolve a entrevista; possibilita captar a expressão corporal do entrevistado, bem como a tonalidade de voz e ênfase nas respostas; há possibilidades de conseguir informações mais precisas, podendo ser comprovadas, de imediato, as discordâncias; possibilita a obtenção de dados referentes aos mais diversos aspectos da vida social, como também a obtenção de dados em profundidade acerca do comportamento humano; os dados obtidos são suscetíveis de classificação e de quantificação.

Limitações - possíveis custos incorridos com treinamento de pessoal e para aplicação das entrevistas; geralmente exige muito tempo; incompreensão do entrevistador sobre o significado das perguntas; a falta de motivação do entrevistado para responder; inadequada compreensão do entrevistado do significado das perguntas; inabilidade ou mesmo incapacidade do entrevistado para responder adequadamente; disposição do entrevistado em fornecer as informações necessárias; influência exercida, consciente ou inconscientemente, pelo pesquisador, devido ao seu aspecto físico, suas atitudes, idéias, opiniões, etc.; fornecimento de repostas falsas ou retenção de dados importantes receando que a identidade do entrevistado seja revelada.

Para subsidiar este estudo, foram realizadas 12 entrevistas semiestruturadas e gravadas em vídeo, com o objetivo de compreender a expectativa dos stakeholders, especialistas e formadores de opinião acerca dos direcionamentos 
que norteariam a estratégia da FPCRJ bem como das ações efetivas esperadas pelos parceiros na formação de rede de colaboração.

\subsection{3.}

\section{Coleta e análise de dados}

A coleta de dados foi realizada por consulta direta aos documentos da Fundação Planetário da Cidade do Rio de Janeiro e da Prefeitura da Cidade do Rio de Janeiro, a saber:

- Plano Estratégico da PCRJ.

- Plano Estratégico da FPCRJ.

- Relatório de emissões de GEE.

- Relatório da GRI.

- Metas institucionais do programa de gestão - Acordo de gestão.

Além da análise documental, foram realizadas oficinas e entrevistas com a alta gestão da FPCRJ, Assessoria Técnica e demais colaboradores e funcionários da instituição.

Realizou-se ainda um estudo dos mapas de processos da FPCRJ, com o intuito de identificar pontos forte e oportunidades de melhorias, visando traçar estratégias e métricas de desempenho que, na dimensão processos internos do BSC, pudessem alavancar tais resultados.

\section{5 .}

\section{Discussão dos resultados}

Neste estudo procurou-se demonstrar que o desenvolvimento de indicadores de desempenho em sustentabilidade aplicáveis à Centros de Difusão de Ciência, Educação e Cultura favorecem uma decisão estratégica assertiva no alcance dos objetivos institucionais.

Um dos principais aspectos levantados nos primeiros encontros da Comissão de Desenvolvimento Sustentável - CSD foi o da necessidade de criar padrões que sirvam de referência para medir o progresso da sociedade em direção ao que se convencionou chamar de um futuro sustentável (MOLDAN E BILLHARZ, 1997).

Com este intuito, percebeu-se um crescimento no que tange aos sistemas 
de medições ou ferramentas para mensuração da sustentabilidade organizacional.

Dentre as ferramentas de mensuração de desempenho sustentável e de elaboração de relatórios de sustentabilidade, a Global Reporting Initiative (GRI), desde a sua criação em 1999, vem se consagrando como a ferramenta de escolha pelas organizações de diversos setores da economia (Brown et al., 2007).

$\mathrm{O}$ relato de sustentabilidade deve auxiliar as organizações, empresas e governo a estabelecer metas, definir os pilares que suportam as atividades de negócios e aferir desempenhos, bem como gerir mudanças com vistas a tornar suas operações mais sustentáveis. Tais relatórios de sustentabilidade divulgam informações sobre os impactos de uma organização, sejam positivos ou negativos, sobre o meio ambiente, a sociedade e a economia. Assim, eles dão a forma tangível e concreta como desejo expresso pela sociedade, a questões abstratas, ajudando as organizações a compreenderem e gerirem melhor os efeitos do desenvolvimento da sustentabilidade sobre suas atividades e estratégias.

Em 2013, a Global Reporting Initiative lançou uma revisão de suas diretrizes G3. De acordo com GRI (2013), a versão G4 inclui referências a relatórios de sustentabilidade amplamente aceitos e utilizados, tendo sido concebida como uma grade analítica consolidada para reportar o desempenho sustentável de organizações de diferentes setores à luz de diferentes códigos e normas para relatórios de sustentabilidade, e desde então, em seus chamados "cadernos setoriais", guias para elaboração do relatório com orientações específicas para cada setor da economia ou ainda por tipos específicos de organizações, conta com a metodologia do CDP, Carbon Disclosure Program.

Cabe ressaltar que a GRI não foi o primeiro modelo desenvolvido com este objetivo, no entanto, devido suas características mais marcantes, simplicidade, liberdade quanto à forma do relato e grau de aprofundamento escalonado, tornou-se referência para as organizações que desejam relatar suas ações de RS e sustentabilidade.

\subsection{1.}

\section{Aplicação do modelo de gestão sustentável de CDCEC à FPCRJ}

O modelo conceitual apresentado neste estudo foi desenvolvido coletivamente através de um projeto de pesquisa-ação com dois anos de duração, 
conduzido na FPCRJ.

Mais especificamente, a motivação da realização deste projeto foi avaliar o potencial da FPCRJ de consolidar o seu papel como agente de transformação social e seu lugar como espaço livre de acesso e de construção do saber, da criatividade e de consciência crítica dos cidadãos cariocas, na perspectiva tríplice da autossustentabilidade econômica, preservação ambiental e equidade social. Em síntese, partiu-se do pressuposto de que a FPCRJ apresentaria vantagens competitivas se apoiasse sua gestão estratégica em uma atitude comprometida com os seus usuários/clientes/públicos, criando um espaço de diálogo e de troca para melhor perceber o que acontece à sua volta, segundo a visão da sustentabilidade econômica, social e ambiental.

Tal filosofia de gestão foi expressa por um conjunto de valores cunhado de 'Planetário 3.0' - em alusão ao conceito de 'Marketing 3.0' proposto por Kotler et al. (2010). São eles:

- Inovação;

- Excelência operacional;

- Transversalidade: cultura-educação-lazer;

- Equidade social;

- Universalização do acesso;

- Valorização do capital humano;

- Colaboração

- Sustentabilidade.

O modelo conceitual apresentado na Figura 7 integra os conceitos apresentados acima com o conceito do Planetário 3.0. Os sete pilares serviram como balizadores para a avaliação dos impactos dos projetos associados a cada Linha Prioritária de Ação, como indicado na Figura a seguir. 


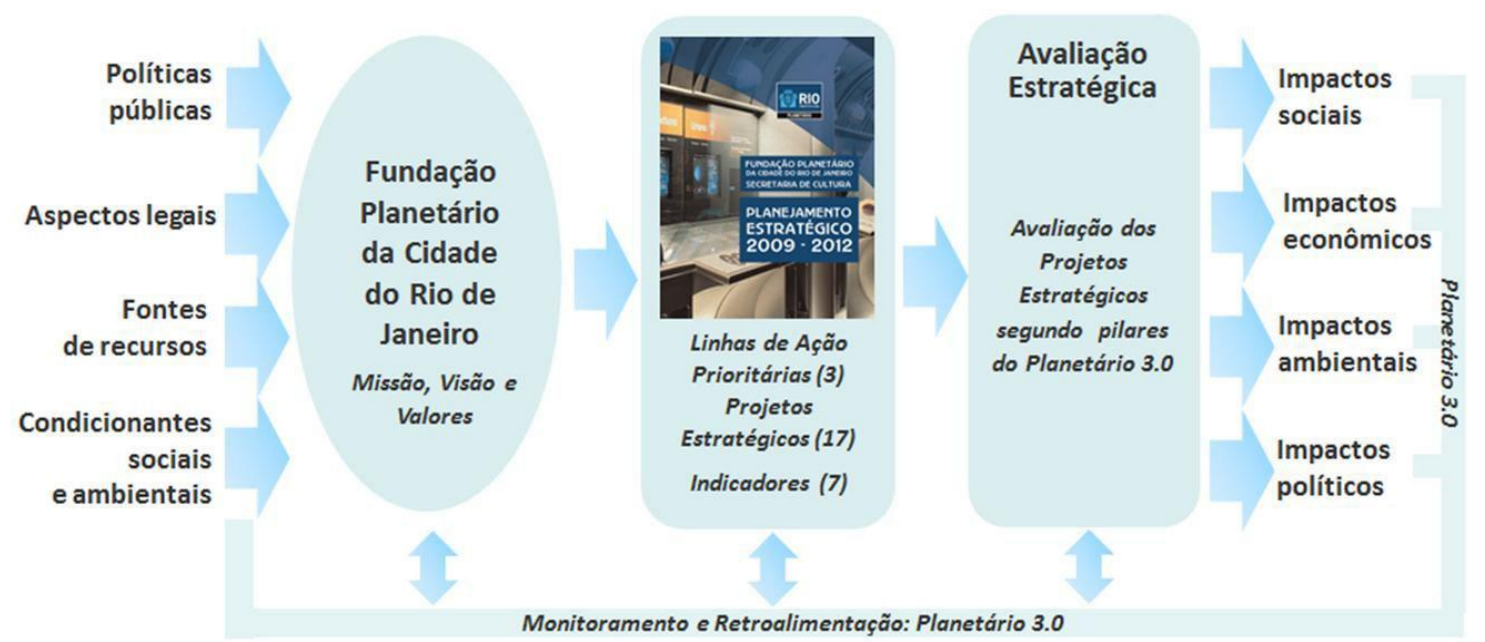

Figura 5.2 - Modelo de gestão sustentável da FPCRJ Fonte: Adaptado do PE 2013-2022 FPCRJ..

Os elementos centrais deste modelo de gestão são: (i) análise das forças motrizes e condicionantes (ambiente externo) e diagnóstico das forças e fraquezas da instituição (ambiente interno); (ii) definição ou revisão dos direcionadores estratégicos da instituição - missão, visão e valores; (iii) processo de planejamento, monitoramento e avaliação estratégica para definição/revisão de objetivos estratégicos, iniciativas e metas de curto, médio e longo prazos, bem como indicadores-chave de desempenho sustentável (KPIs); (iv) desdobramento dos objetivos estratégicos e metas em planos que integrarão o Plano TáticoOperacional da instituição; e (v) avaliação do desempenho sustentável baseado no conceito de 'Marketing 3.0' (Kotler et al., 2010; 2008) e em um conjunto de valores que no caso da FPCRJ foi denominado de 'Planetário 3.0'.

\subsection{2.}

Planejamento Estratégico da FPCRJ 2013-2022: um processo participativo e balanceado em torno dos três pilares da sustentabilidade

A partir dos conceitos introduzidos por Kaplan e Norton (1996), que posteriormente foram adaptados por Bieker et al. (2001), Brignal (2002) e Figge et al. (2002), a FPCRJ adotou a ferramenta cunhada por Figge et al. como "Balanced scorecard sustentável", visando a efetiva implementação de uma estratégia corporativa que considerasse as três dimensões da sustentabilidade 
(abordagem Triple Bottom Line, divulgada por Elkington em sua obra de 1998). A construção coletiva do mapa estratégico sustentável da FPCRJ

começou com a definição de 20 objetivos estratégicos, que formariam os blocos centrais da estratégia corporativa. As relações de causa e efeito entre os objetivos estratégicos foram evidenciadas no desenho do mapa estratégico, como pode ser observado na Figura 8.

A partir dessa criação coletiva, procedeu-se a uma discussão sobre as relações entre os valores institucionais (Planetário 3.0), os indicadores de desempenho sustentável e as iniciativas estratégicas, para as quais deveriam ser traçados planos de ação específicos com os respectivos responsáveis dentro da FPCRJ. Os resultados finais deste processo foram consolidados no 'Mapa Estratégico Sustentável da FPCRJ', diagramado em quatro dimensões: 'Sustentabilidade', 'Clientes', 'Processos internos', e 'Aprendizagem e crescimento' (Figura 8).

A ferramenta BSC sustentável forneceu um quadro abrangente capaz de traduzir os objetivos estratégicos da FPCRJ em um conjunto coerente de planos de ação e indicadores-chave de desempenho e métricas. Sua adoção pela FPCRJ representou uma mudança fundamental nos pressupostos subjacentes sobre desempenho sustentável, que incluíram indicadores sociais e ambientais, além dos econômico-financeiros.

$\mathrm{Na}$ Figura 8, pode-se ver como as peças se juntam para expressar de forma objetiva e concatenada a estratégia corporativa da FPCRJ. As elipses representam os objetivos estratégicos, que são dispostos em camadas, conforme as dimensões definidas pela instituição. As dimensões das camadas inferiores 'processos internos' e 'aprendizagem e crescimento' - compreendem objetivos estratégicos de suporte e respectivos indicadores de processo. Já as camadas superiores - 'clientes' e 'sustentabilidade' expressam os objetivos voltados para resultados associados ao atendimento aos públicos-alvo e à sociedade em geral. Ao seguir os fluxos e as setas do mapa, podem também ser identificados os valores do Planetário 3.0, segundo os quais as iniciativas e ações correspondentes a cada objetivo estratégico deverão ser pautadas. 


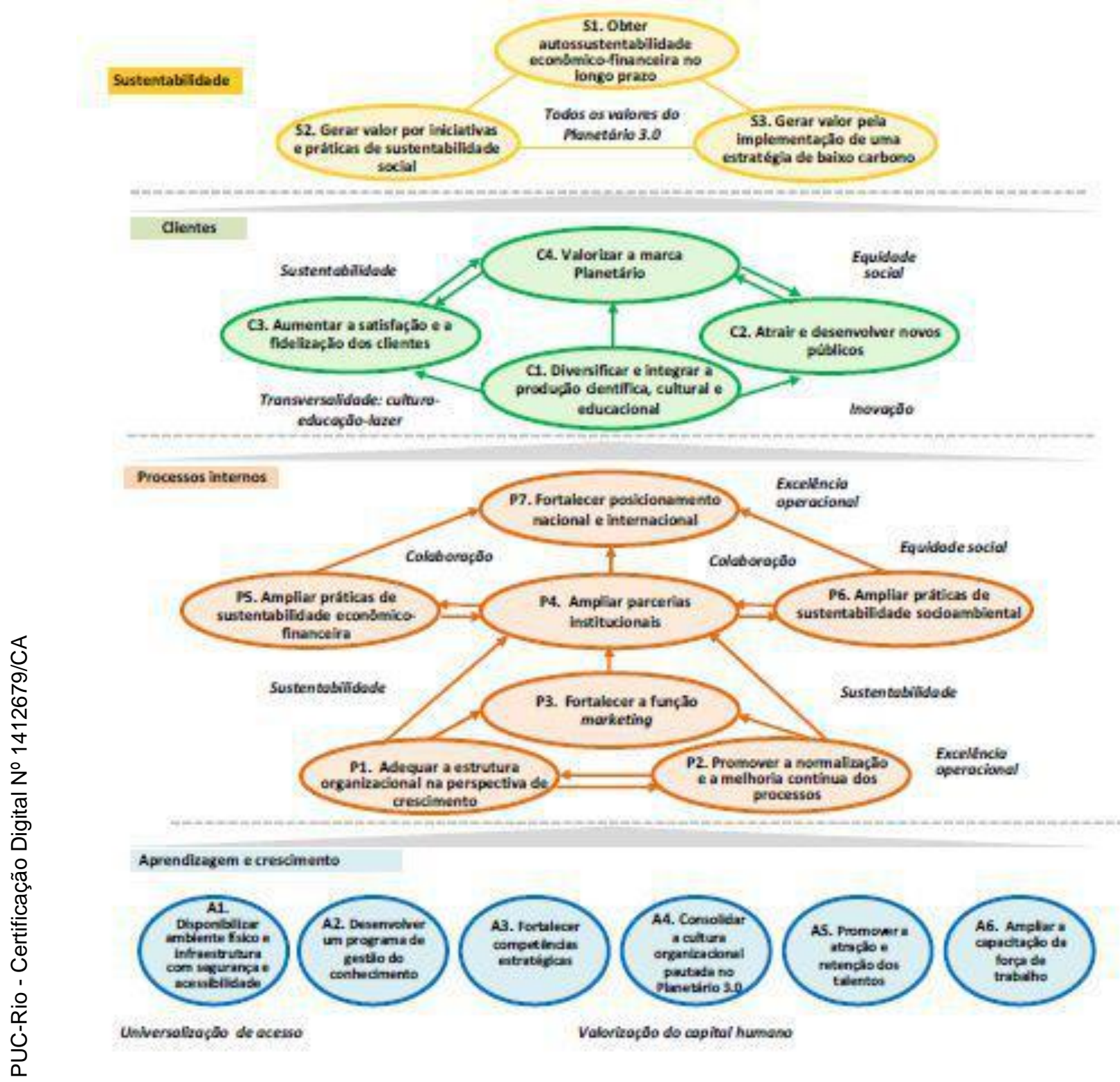

Figura 5.3 - Mapa estratégico sustentável da FPCRJ Fonte: Extraído do PE 2013-2022 FPCRJ

Ao vincular os 20 objetivos estratégicos no nível corporativo com os objetivos das áreas departamentais, chegando-se esse vínculo ao nível dos colaboradores, obtém-se um alinhamento objetivo entre missão institucional, estratégia corporativa e departamental e objetivos pessoais a serem alcançados. Da mesma forma, iniciativas estratégicas e indicadores-chave de desempenho (KPIs) são associados a cada objetivo estratégico.

O Quadro 5.1, abaixo, resume os resultados do processo de planejamento 
estratégico da FPCRJ.

Quadro 5.1 - Síntese dos resultados do projeto de pesquisa-ação na FPCRJ

\begin{tabular}{|c|c|c|}
\hline Dimensão & Objetivos estratégicos 2013-2022 & Iniciativas \\
\hline Sustentabilidade & 3 & - \\
\hline Clientes & 4 & 12 \\
\hline Processos internos & 7 & 16 \\
\hline $\begin{array}{c}\text { Aprendizagem e } \\
\text { crescimento }\end{array}$ & 6 & 7 \\
\hline Total: 4 dimensões & 20 objetivos estratégicos & 35 iniciativas \\
\hline
\end{tabular}

Fonte: Adaptado do PE 2013-2022 FPCRJ

\subsection{3. \\ Monitoramento e avaliação do desempenho sustentável da FPCRJ: integração do BSC sustentável com as diretrizes da GRI}

O conjunto de KPIs da FPCRJ foi definido com o objetivo principal de medir o progresso da instituição em relação ao alcance dos objetivos estratégicos de sustentabilidade, como já mencionado.

A coleta de dados para comunicar o desempenho sustentável da FPCRJ também foi considerada crítica, uma vez que a elaboração de relatórios de sustentabilidade passou a ser um importante mecanismo para as instituições demonstrarem o cumprimento ou perseguir sua materialização. Buscando superar esses desafios, adotou-se a ferramenta conhecida como matriz de materialidade, a partir das informações e premissas que nortearam o processo de planejamento estratégico durante o projeto de pesquisa-ação na FPCRJ (Figura 5.4). 


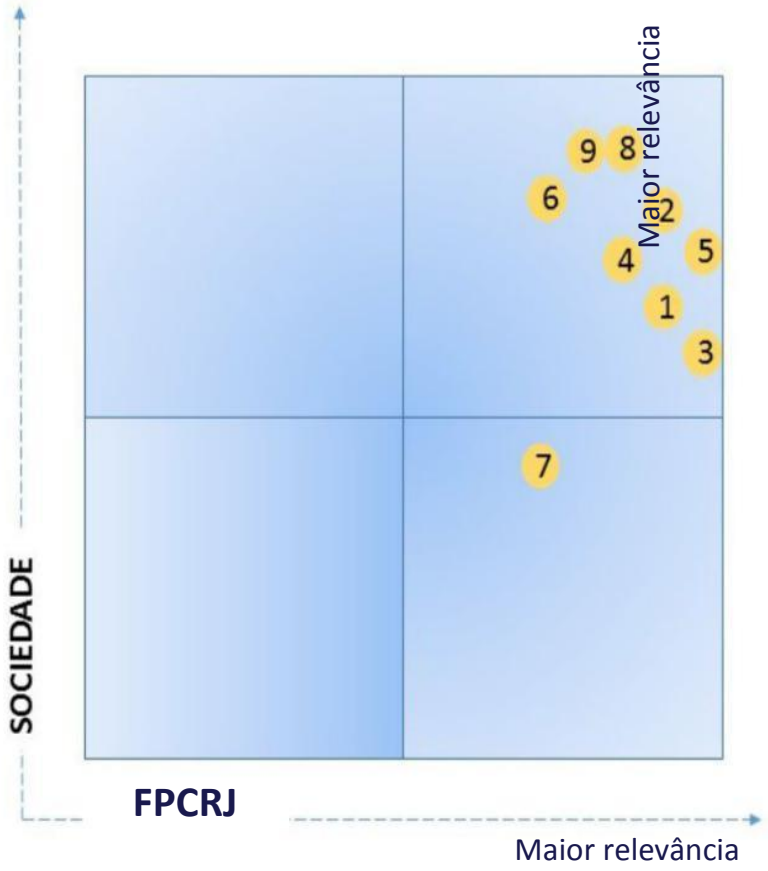

1 Consumo Energético

2 Mudanças Climáticas

3 Relacionamento com o cliente

4 Desempenho Ambiental

5 Popularização da ciência e tecnologia

6 Satisfação do cliente

7 Resultado Financeiro

8 Educação para a Sustentabilidade

9 Treinamento e Desenvolvimento

Figura 5.4 - Matriz de materialidade da FPCRJ Fonte: Adaptado do PE 2013-2022 FPCRJ

O uso dessa ferramenta permitiu definir os temas que deveriam ser objeto da proposição de indicadores de sustentabilidade, que impactam direta ou indiretamente a habilidade da FPCRJ de criar, preservar ou gerar valor econômico, social e ambiental para si, suas partes interessadas e a sociedade.

Cabe ressaltar que, no nível internacional, os relatórios anuais de alguns dos principais Museus de Ciência e História Natural e Planetários da Europa e da América do Norte tem feito pouca menção às questões da sustentabilidade, apesar de algumas iniciativas relevantes terem sido reportadas em trabalhos acadêmicos (Pop e Sabou, 2013; Adams, 2010). Nesse sentido, a construção da matriz de materialidade pela FPCRJ pode ser considerada uma boa prática a ser replicada em outros CDCEC aqui no Brasil e também em nível mundial.

De fato, não há indicadores que foram projetados especificamente para Planetários e instituições congêneres. Por sua vez, como mencionado anteriormente, existem diretrizes gerais e modelos para medir o desempenho sustentável - por exemplo, as Diretrizes para Relatórios de Sustentabilidade Versão 4.0 (G4) da Global Reporting Initiative. As diretrizes GRI foram concebidas para ser universalmente aplicáveis a todas as organizações, grandes e pequenas, em todo o mundo (GRI, 2013).

A adaptação para os contextos de Centros de Difusão de Ciência, 
Educação e Cultura (CDCEC) e alinhamento às Diretrizes da GRI foram as premissas para a construção de um conjunto de indicadores-chave de desempenho (KPIs) associados às quatro dimensões do Mapa Estratégico Sustentável da FPCRJ (Figura 5.3).

Quadro 5.2 - Síntese da proposição de indicadores-chave (KPIs) à luz das Diretrizes GRI

\begin{tabular}{llll}
\hline Dimensão & $\begin{array}{l}\text { Objetivos estratégicos } \\
\mathbf{2 0 1 3 - 2 0 2 2}\end{array}$ & Indicadores KPIs & Indicadores GRI \\
\hline Sustentabilidade & 3 & 3 & 12 \\
\hline Clientes & 4 & 10 & +2 \\
\hline Processos internos & 7 & 10 & +2 \\
\hline $\begin{array}{l}\text { Aprendizagem e } \\
\text { crescimento }\end{array}$ & 6 & 8 & +4 \\
\hline $\begin{array}{l}\text { Total: } 4 \\
\text { dimensões }\end{array}$ & 20 objetivos & & \\
& estratégicos & 31 KPIs & (10 indicadores \\
& & & GRI \\
\hline
\end{tabular}

Fonte: Elaboração própria

Os quadros a seguir, mostram os indicadores-chaves estabelecidos para medir o desempenho e progresso da FPCRJ em direção à sustentabilidade, elaborados com base no BSC sustentável, com indicadores e métricas de desempenho sustentável, observando os aspectos da GRI bem como as iniciativas estratégicas da Fundação Planetário da Cidade do Rio de Janeiro, expostas em seu PE 2013-2022.

Tais indicadores expressam sua visão de futuro e estão demonstrados em um quadro que respeita a proposta do PE, construído segundo a proposta do Balanced Scorecard sustentável e agregados em 4 dimensões: sustentabilidade, clientes, processos internos e aprendizagem e crescimento. 
Quadro 5.3 - Indicadores estratégicos para o BSC à luz da GRI

\begin{tabular}{|c|c|c|c|c|c|c|}
\hline \multicolumn{7}{|c|}{ Dimensão: Sustentabilidade } \\
\hline $\begin{array}{l}\text { Objetivo } \\
\text { estratégico }\end{array}$ & Indicador BSC & Indicador GRI & Métrica & $\begin{array}{l}\text { Linha de base } \\
\text { (2013) e Metas }\end{array}$ & Frequência & $\begin{array}{l}\text { Iniciativas } \\
\text { estratégicas }\end{array}$ \\
\hline $\begin{array}{l}\quad \text { S1. Obter } \\
\text { autossustenta- } \\
\text { bilidade } \\
\text { econômico- } \\
\text { financeira } \\
\text { longo prazo }\end{array}$ & \begin{tabular}{l}
\multicolumn{1}{c}{ IS1. Indice } \\
de sustentabilidade \\
econômico- \\
financeira
\end{tabular} & $\begin{array}{l}\quad \text { EC1 - Valor } \\
\text { gerado pela } \\
\text { arrecadação + } \\
\text { custeios, sem folha } \\
\text { de pagamento,+ } \\
\text { investimentos } \\
\text { (recursos captados } \\
\text { de fontes externas + } \\
\text { contrapartida) } \\
\quad \text { EC4- } \\
\text { Recursos do } \\
\text { Tesouro Municipal } \\
\text { + captação de } \\
\text { fontes } \\
\text { governamentais; } \\
\quad \text { EC8 - } \\
\text { Investimentos em } \\
\text { infraestrutura com } \\
\text { benefícios públicos }\end{array}$ & $\begin{array}{l}\text { radial: } \\
\text { Indicador composto em formato } \\
\text { Investimento = [volume de } \\
\text { recursos captados de fontes } \\
\text { externas/(volume de recursos captados de } \\
\text { fontes externas + contrapartida)] } \\
\text { Custeio = [volume de recursos } \\
\text { arrecadados /(volume de recursos } \\
\text { arrecadados + volume de recursos do } \\
\text { Tesouro Municipal)] } \\
\quad \text { Redução de custeio = [volume de } \\
\text { recursos economizados/ volume de } \\
\text { recursos de custeio do exercício anterior] } \\
\quad \text { Nota: folha de pagamento } \\
\text { (nomeados e concursados) não entra em } \\
\text { custeio }\end{array}$ & $\begin{array}{l}\text { Linha de base } \\
\text { (2012) e metas para } \\
\text { curto, médio e longo } \\
\text { prazos }\end{array}$ & Anual & Não se aplica \\
\hline $\begin{array}{lr}\text { S2. } & \text { Gerar } \\
\text { valor } & \text { por } \\
\text { iniciativas } & \mathrm{e} \\
\text { práticas } & \mathrm{de} \\
\text { sustentabilidade } \\
\text { social }\end{array}$ & $\begin{array}{l}\text { IS2. Grau de } \\
\text { sustentabilidade } \\
\text { social }\end{array}$ & $\begin{array}{l}\quad \text { SO1 - } \\
\text { Impactos das } \\
\text { operações na } \\
\text { comunidade }\end{array}$ & $\begin{array}{l}\text { Número de pessoas impactadas } \\
\text { pelos projetos sociais/ Número total de } \\
\text { visitantes } \\
\text { Nota1: visitantes = número de } \\
\text { visitantes às instalações físicas, } \\
\text { itinerantes, eventos culturais etc. } \\
\text { Nota2: Analisar possível inclusão } \\
\text { de ES17 e E19. }\end{array}$ & $\begin{array}{l}\text { Linha de base } \\
\text { (2012) e metas para } \\
\text { curto, médio e longo } \\
\text { prazos }\end{array}$ & Anual & Não se aplica \\
\hline
\end{tabular}


Indicadores estratégicos para o BSC à luz da GRI (cont.)

\begin{tabular}{|c|c|c|c|c|c|c|}
\hline \multicolumn{7}{|c|}{ Dimensão: Sustentabilidade } \\
\hline $\begin{array}{l}\text { Objetivo } \\
\text { estratégico }\end{array}$ & Indicador BSC & Indicador GRI & Métrica & $\begin{array}{l}\text { Linha de base } \\
\text { (2013) e Metas }\end{array}$ & Frequência & $\begin{array}{l}\text { Iniciativas } \\
\text { estratégicas }\end{array}$ \\
\hline 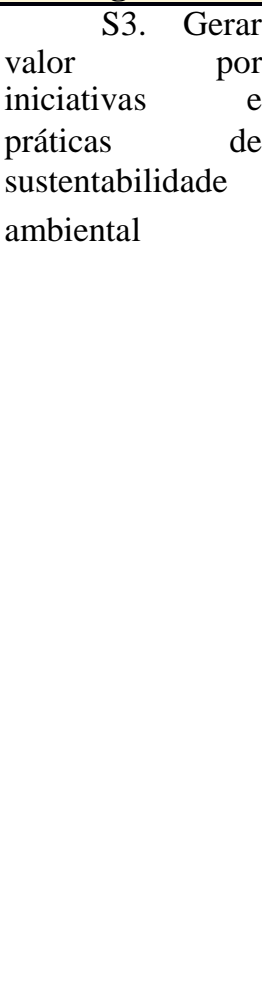 & $\begin{array}{l}\text { IS3. Grau de } \\
\text { sustentabilidade } \\
\text { ambiental }\end{array}$ & $\begin{array}{l}\text { EN3 - } \\
\text { consumo de energia } \\
\text { direta por fonte } \\
\text { EN4 - } \\
\text { consumo de energia } \\
\text { indireta } \\
\text { EN5 - } \\
\text { conservação de } \\
\text { energia } \\
\text { EN6 - } \\
\text { redução de } \\
\text { consumo por } \\
\text { serviço } \\
\text { EN10 - } \\
\text { Reuso de água } \\
\text { EN 16- } \\
\text { Emissões GEE } \\
\text { EN17 - } \\
\text { Outras Emissões } \\
\text { GEE } \\
\text { EN22 - } \\
\text { Geração e } \\
\text { tratamento de } \\
\text { resíduos }\end{array}$ & $\begin{array}{l}\text { IS3: Indicador composto em } \\
\text { formato radial } \\
\underline{\text { Energia }} \\
\text { Economia de energia por } \\
\text { iniciativas de conservação de energia } \\
\text { (kWh/ano)/ Consumo de energia total } \\
\text { Consumo de energia total/ } \\
\text { número de visitantes às instalações } \\
\text { fixas (kWh/ano/ número de visitantes } \\
\text { às instalações fixas } \\
\underline{\text { Emissões GEE }} \\
\text { kg CO2 eq/ano/ número de } \\
\text { visitantes às instalações fixas } \\
\frac{\text { Resíduos }}{\text { Peso de resíduos gerados/ }} \\
\text { número de visitantes às instalações } \\
\text { fixas (kg/ano/visitante) } \\
\frac{\text { Água }}{\mathrm{m}^{3} \text { de água reutilizada/ano/ }} \\
\text { total de consumo de água/ano }\end{array}$ & $\begin{array}{l}\text { Linha de base } \\
\text { (2013) e metas para } \\
\text { curto, médio e longo } \\
\text { prazos }\end{array}$ & Anual & Não se aplica \\
\hline \begin{tabular}{l}
\multicolumn{1}{c}{3} \\
objetivos \\
estratégicos
\end{tabular} & $\begin{array}{c}3 \\
\text { indicadores } \mathrm{BSC}\end{array}$ & $\begin{array}{c}12 \\
\text { indicadores GRI }\end{array}$ & & & & $\begin{array}{l}\text { Nenhuma } \\
\text { iniciativa }\end{array}$ \\
\hline
\end{tabular}


Indicadores estratégicos para o BSC à luz da GRI (cont.)

\begin{tabular}{|c|c|c|c|c|c|c|}
\hline \multicolumn{7}{|c|}{ imensão: Clientes } \\
\hline $\begin{array}{l}\text { Objetivo } \\
\text { estratégico }\end{array}$ & Indicador BSC & Indicador GRI & Métrica & $\begin{array}{l}\text { Linha de base } \\
\text { (2013) e Metas }\end{array}$ & Frequência & $\begin{array}{l}\text { Iniciativas } \\
\text { estratégicas }\end{array}$ \\
\hline \multirow[t]{2}{*}{\begin{tabular}{l}
\multicolumn{1}{c}{ C1. } \\
Diversificar e \\
integrar a \\
produção \\
científica, \\
cultural e \\
educacional
\end{tabular}} & \begin{tabular}{l}
\multicolumn{1}{c}{ IC1 - Grau } \\
de integração da \\
produção científica, \\
cultural e \\
educacional
\end{tabular} & $\begin{array}{l}\text { EC6- } \\
\text { Gastos com } \\
\text { fornecedores locais } \\
\quad \text { EC } 8 \text { - } \\
\text { Infraestrutura com } \\
\text { benefícios públicos } \\
\quad \text { PR5 - } \\
\text { Práticas voltadas } \\
\text { para a satisfação do } \\
\text { cliente }\end{array}$ & $\begin{array}{l}\text { IC1: Indicador composto com } \\
\text { formato radial } \\
\text { Projetos elaborados por equipe } \\
\text { multidisciplinar e transversal/ número } \\
\text { total de projetos das atividades fim. } \\
\text { Volume de recursos destinados } \\
\text { para fornecedores locais/ano } \\
\text { Investimentos } \\
\text { infraestrutura com } \\
\text { públicos/ano benefícios }\end{array}$ & $\begin{array}{l}\text { Linha de base } \\
(2013) \text { e metas para } \\
\text { curto, médio e longo } \\
\text { prazos }\end{array}$ & Anual & 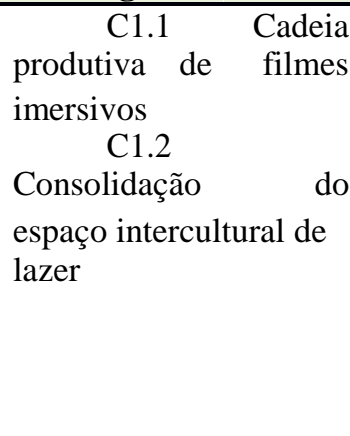 \\
\hline & $\begin{array}{l}\text { IC2 }- \text { Grau } \\
\text { de inovação nos } \\
\text { serviços e produtos } \\
\text { da FPCRJ } \\
\quad \text { IC3 - Grau } \\
\text { de adequação do } \\
\text { aparelho } \\
\text { educacional em } \\
\text { relação às grades } \\
\text { curriculares do } \\
\text { ensino fundamental } \\
\text { e médio }\end{array}$ & $\begin{array}{l}\quad \text { PR5 - } \\
\text { Práticas voltadas } \\
\text { para a satisfação do } \\
\text { cliente }\end{array}$ & $\begin{array}{l}\text { IC2: Indicador composto com } \\
\text { formato radial } \\
\text { Número de novos filmes, } \\
\text { programas e exposições/ total de } \\
\text { produtos ofertados/período. } \\
\text { Número de pessoas/faixa de } \\
\text { satisfação em relação ao novo } \\
\text { produto/Número total } \\
\text { respondentes } \\
\text { IC3: Número de escolas/nível } \\
\text { escolar/faixa de satisfação em relação } \\
\text { ao aparelho educacional/Número } \\
\text { total de escolas atendidas. }\end{array}$ & $\begin{array}{l}\text { Linha de base } \\
\text { (2013) e metas para } \\
\text { curto, médio e longo } \\
\text { prazos }\end{array}$ & Anual & $\begin{array}{l}\text { C1.3 Inovação } \\
\text { nos serviços e produtos } \\
\text { da FPCRJ }\end{array}$ \\
\hline
\end{tabular}


Indicadores estratégicos para o BSC à luz da GRI (cont.)

Dimensão: Clientes

\begin{tabular}{|c|c|c|c|c|c|c|}
\hline $\begin{array}{l}\text { Objetivo } \\
\text { estratégico }\end{array}$ & Indicador BSC & Indicador GRI & Métrica & $\begin{array}{l}\text { Linha de base } \\
(2013) \text { e Metas }\end{array}$ & Frequência & $\begin{array}{l}\text { Iniciativas } \\
\text { estratégicas }\end{array}$ \\
\hline $\begin{array}{l}\text { C2. Atrair } \\
\text { e desenvolver } \\
\text { novos públicos }\end{array}$ & $\begin{array}{l}\quad \text { IC4 - } \\
\text { Impacto das } \\
\text { atividades } \\
\text { científicas, } \\
\text { educacionais e } \\
\text { culturais } \\
\quad \text { IC5 - } \\
\text { Impacto da } \\
\text { gratuidade } \\
\quad \text { IC6 - } \\
\text { Investimento em } \\
\text { Novas Unidades no } \\
\text { Município do Rio } \\
\text { de Janeiro }\end{array}$ & $\begin{array}{l}\quad \text { SO1 - } \\
\text { Impactos das } \\
\text { operações na } \\
\text { comunidade } \\
\quad \text { EC8 }- \\
\text { Infraestrutura com } \\
\text { benefícios públicos }\end{array}$ & $\begin{array}{l}\text { IC4: Indicador composto com } \\
\text { formato radial } \\
\text { Número de atividades } \\
\text { científicas, educacionais e culturais } \\
\text { com alto impacto social/total de } \\
\text { atividades científicas, educacionais e } \\
\text { culturais (Planetário sem fronteiras; } \\
\text { Planetário social) } \\
\quad \text { Número de atividades } \\
\text { científicas, educacionais e culturais } \\
\text { com impacto no turismo/ total de } \\
\text { atividades científicas, educacionais e } \\
\text { culturais (Planetário-Turismo) } \\
\quad \text { Número de experimentos } \\
\text { publicados online/total } \\
\text { experimentos (Nave-escola e Museu } \\
\text { do Universo) } \\
\text { IC5: Número de pessoas } \\
\text { beneficiadas pela } \\
\text { gratuidade/segmento/ano } \\
\underline{\text { IC6: Investimento em novas }} \\
\text { Unidades no Município do Rio de } \\
\text { Janeiro/número visitantes (potencial) }\end{array}$ & $\begin{array}{l}\text { Linha de base } \\
\text { (2013) e metas para } \\
\text { curto, médio e longo } \\
\text { prazos }\end{array}$ & Anual & $\begin{array}{l}\text { C2.1 Planetário } \\
\text { sem fronteiras } \\
\text { C2.2 Planetário } \\
\text { social } \\
\text { C2.3 Planetário } \\
\text { para todos } \\
\text { C2.4 Novas } \\
\text { Unidades no Município } \\
\text { do Rio de Janeiro } \\
\text { C2.5 Planetário- } \\
\text { Turismo }\end{array}$ \\
\hline
\end{tabular}


Indicadores estratégicos para o BSC à luz da GRI (cont.)

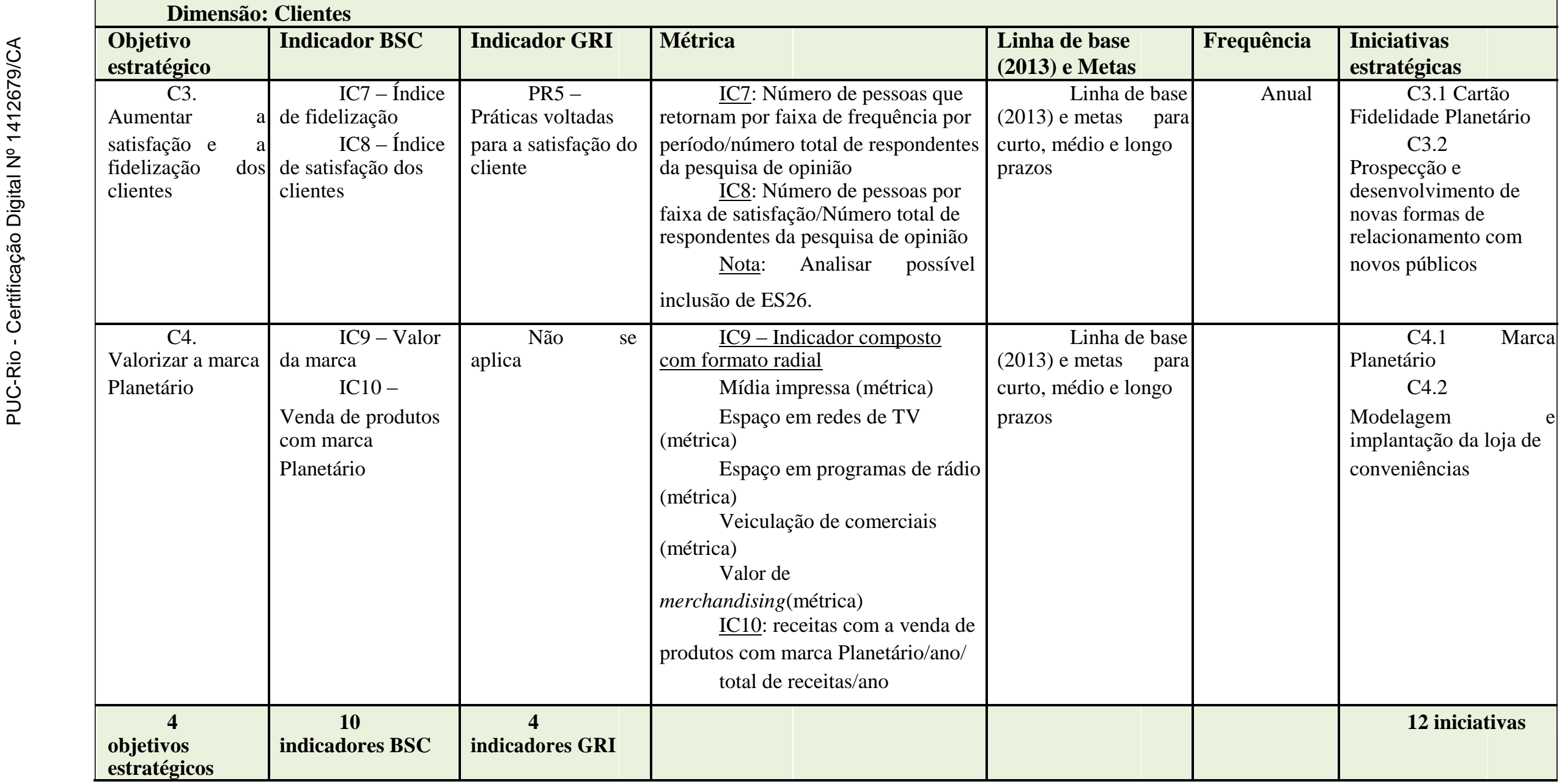


Indicadores estratégicos para o BSC à luz da GRI (cont.)

\begin{tabular}{|c|c|c|c|c|c|c|}
\hline \multicolumn{7}{|c|}{ Dimensão: Processos internos } \\
\hline $\begin{array}{l}\text { Objetivo } \\
\text { estratégico }\end{array}$ & Indicador BSC & $\begin{array}{l}\text { Indicador } \\
\text { GRI }\end{array}$ & Métrica & \begin{tabular}{|l} 
Linha de base \\
(2013) e Metas
\end{tabular} & Frequência & \begin{tabular}{|l|} 
Iniciativas \\
estratégicas
\end{tabular} \\
\hline $\begin{array}{l}\quad \text { P1. Adequar } \\
\text { a estrutura } \\
\text { organizacional na } \\
\text { perspectiva de } \\
\text { crescimento }\end{array}$ & $\begin{array}{l}\quad \text { IP1 - Grau de } \\
\text { adequação da estrutura } \\
\text { organizacional }\end{array}$ & $\begin{array}{lll} & \text { Não } & \text { se } \\
\text { aplica } & & \end{array}$ & $\begin{array}{l}\quad \underline{\text { IP1: Pesquisa interna junto aos gestores }} \\
\text { e força de trabalho sobre a adequação da } \\
\text { estrutura organizacional em relação ao } \\
\text { desempenho das funções/atividade }\end{array}$ & $\begin{array}{l}\text { Linha de } \\
\text { base (2013) e metas } \\
\text { para curto, médio e } \\
\text { longo prazos }\end{array}$ & Anual & $\begin{array}{l}\text { P1.1 Adequação } \\
\text { organizacional }\end{array}$ \\
\hline \begin{tabular}{l}
\multicolumn{1}{c}{ P2. } \\
Promover a \\
normalização e a \\
melhoria contínua \\
dos processos \\
\end{tabular} & $\begin{array}{l}\text { IP2 - Pontuação } \\
\text { PQRio }\end{array}$ & aplica $\quad$ Não se & $\begin{array}{l}\text { IP2: Métricas associadas à pontuação } \\
\text { PQRio }\end{array}$ & $\begin{array}{l}\text { Linha de } \\
\text { base (2013) e metas } \\
\text { para curto, médio e } \\
\text { longo prazos }\end{array}$ & Anual & $\begin{array}{l}\text { P2.1 Sistema de } \\
\text { gestão da qualidade } \\
\text { P2.2 Melhoria } \\
\text { contínua dos processos de } \\
\text { trabalho } \\
\end{array}$ \\
\hline $\begin{array}{l}\text { P3. } \\
\text { Fortalecer a função } \\
\text { marketing }\end{array}$ & \begin{tabular}{|l|}
\multicolumn{2}{|c|}{ IP3 - Grau de } \\
maturidade da função \\
marketing \\
\multicolumn{1}{|c|}{ Nota: Maturidade é } \\
a extensão em que a função \\
ou processo é \\
explicitamente definida, \\
gerenciada, medida, \\
controlada e eficaz. O \\
conceito básico sob o termo \\
maturidade é de que as \\
organizações maduras \\
fazem as coisas de modo \\
sistemático. \\
\end{tabular} & $\begin{array}{ll}\text { Não } & \text { se } \\
\text { aplica } & \end{array}$ & $\begin{array}{l}\quad \underline{\text { IP3 }} \text { : Nível de maturidade da função } \\
\text { marketing medido pelo conjunto de atributos } \\
\text { que caracterizam o estágio da capacidade de } \\
\text { seus processos. (5 níveis: } 1 \text { - informal; } 2 \text { - } \\
\text { organizado; 3- bem estruturado; } 4 \text {-gerenciado; } \\
5 \text { - otimizado). } \\
\text { Eota: Analisar possível inclusão de } \\
\text { ES20, ES23 e ES24 }\end{array}$ & $\begin{array}{l}\text { Linha de } \\
\text { base (2013) e metas } \\
\text { para curto, médio e } \\
\text { longo prazos }\end{array}$ & Anual & $\begin{array}{l}\text { P3.1 Função } \\
\text { marketing }\end{array}$ \\
\hline $\begin{array}{l}\quad \text { P4. } \\
\text { Fortalecer } \\
\text { posicionamento } \\
\text { nacional e } \\
\text { internacional }\end{array}$ & $\begin{array}{l}\text { IP4 - Nível GRI }(\mathrm{C}, \\
\mathrm{B}, \mathrm{B}+, \mathrm{A}) \\
\quad \text { IP5 - } \\
\text { Posicionamento } \\
\text { institucional (Brasil e } \\
\text { mundo) } \\
\quad \text { IP6 - Candidatura e } \\
\text { defesa do RIOIPS 2020 }\end{array}$ & $\begin{array}{l}\text { Indicadore } \\
\text { s selecionados } \\
\text { GRI/período }\end{array}$ & $\begin{array}{l}\text { IP4: Métricas dos indicadores GRI } \\
\text { selecionados/período } \\
\text { IP5: Indicador composto com métricas } \\
\text { de desempenho (KPIs) } \\
\underline{\text { IP6: Projeto de candidatura e defesa do }} \\
\text { RIO IPS } 2020 \text { realizado/planejado } \\
\quad \underline{\text { Nota: }} \text { Analisar possível inclusão ES21. }\end{array}$ & \begin{tabular}{l}
\multicolumn{2}{c}{ Conforme } \\
níveis GRI $(\mathrm{C}, \mathrm{B}$, \\
B+, A) Linha de \\
base (2013) e metas \\
para curto, médio e \\
longo prazos
\end{tabular} & Anual & $\begin{array}{l}\text { P4.1 Planetário } \\
\text { como referência } \\
\text { internacional } \\
\quad \text { P4.2 Global } \\
\text { Reporting Initiative (GRI) } \\
\quad \text { P4.3 Rio IPS } \\
2020\end{array}$ \\
\hline
\end{tabular}


Indicadores estratégicos para o BSC à luz da GRI (cont.)

\begin{tabular}{|c|c|c|c|c|c|c|}
\hline \multicolumn{7}{|c|}{ Dimensão: Processos internos } \\
\hline $\begin{array}{l}\text { Objetivo } \\
\text { estratégico }\end{array}$ & Indicador BSC & Indicador GRI & Métrica & $\begin{array}{l}\text { Linha de base } \\
\text { (2013) e Metas }\end{array}$ & Frequência & $\begin{array}{l}\text { Iniciativas } \\
\text { estratégicas }\end{array}$ \\
\hline \begin{tabular}{l}
\multicolumn{1}{c}{ P5. } \\
Ampliar parcerias \\
institucionais
\end{tabular} & $\begin{array}{l}\text { IP7 - Produção } \\
\text { em parceira } \\
\text { IP8 - Taxa de } \\
\text { crescimento de } \\
\text { voluntariado }\end{array}$ & \begin{tabular}{lr}
\multicolumn{1}{c}{ SO1 } & - \\
Impactos & das \\
operações & na \\
comunidade & \\
(voluntariado) &
\end{tabular} & $\begin{array}{l}\text { IP7: Número de serviços e projetos } \\
\text { realizados em parceria/ Número de serviços } \\
\text { e projetos realizados/ano } \\
\text { IP8: Taxa de crescimento de } \\
\text { voluntariado/ano em relação ao ano base } \\
\text { (2013) }\end{array}$ & $\begin{array}{l}\text { Linha de } \\
\text { base (2013) e metas } \\
\text { para curto, médio e } \\
\text { longo prazos }\end{array}$ & Anual & $\begin{array}{r}\text { P5.1 } \\
\text { colaborativa }\end{array}$ \\
\hline \begin{tabular}{l}
\multicolumn{1}{c}{ P6. } \\
Ampliar práticas \\
de \\
sustentabilidade \\
econômico- \\
financeira
\end{tabular} & $\begin{array}{l}\quad \text { IP9 }- \text { Índice de } \\
\text { aprovação de projetos de } \\
\text { diversas modalidades de } \\
\text { captação de recursos }\end{array}$ & $\begin{array}{l}\quad \text { EC1 - Valor } \\
\text { gerado } \\
\qquad \text { EC4 - Ajuda } \\
\text { financeira recebida do } \\
\text { governo } \\
\qquad \text { EC9 - } \\
\text { impactos econômicos } \\
\text { indiretos } \\
\text { significativos, } \\
\text { incluindo a extensão } \\
\text { dos impactos. }\end{array}$ & $\begin{array}{l}\underline{\text { IP9 - Indicador composto com }} \\
\text { formato radial } \\
\underline{\text { Captação: valor econômico }} \\
\text { referente a projetos aprovados/número de } \\
\text { projetos submetidos/modalidade de } \\
\text { captação de recursos/ano; } \\
\text { Arrecadação: taxa de crescimento } \\
\text { de arrecadação/ano em relação ao ano base } \\
(2013) ; \\
\text { Redução de custos: taxa de redução } \\
\text { de custos/ano em relação ao ano base } \\
\text { (2013); } \\
\text { Comércio recíproco: benefícios } \\
\text { econômicos dos projetos de comércio } \\
\text { recíproco/ano. }\end{array}$ & $\begin{array}{l}\text { Linha de } \\
\text { base (2013) e metas } \\
\text { para curto, médio e } \\
\text { longo prazos }\end{array}$ & Anual & $\begin{array}{l}\text { P6.1 Captação de } \\
\text { recursos } \\
\text { P6.2 Arrecadação } \\
\text { P6.3 Redução de } \\
\text { custos } \\
\text { P6.4 Comércio } \\
\text { recíproco }\end{array}$ \\
\hline \begin{tabular}{l}
\multicolumn{1}{c}{ P7. } \\
Ampliar práticas \\
de \\
sustentabilidade \\
ambiental
\end{tabular} & $\begin{array}{l}\text { IP10. Práticas de } \\
\text { sustentabilidade } \\
\text { ambiental }\end{array}$ & $\begin{array}{l}\quad \text { EN6 - } \\
\text { Serviços e produtos } \\
\text { com baixo consumo } \\
\text { etc.; EN18 - } \\
\text { Iniciativas para } \\
\text { reduzir as emissões } \\
\text { GEE }\end{array}$ & $\begin{array}{l}\quad \underline{\text { IP10. Número de práticas }} \\
\text { ambientais de alto impacto } \\
\text { realizadas/iniciativas ambientais planejadas }\end{array}$ & $\begin{array}{l}\quad \text { Linha de } \\
\text { base (2013) e metas } \\
\text { para curto, médio e } \\
\text { longo prazos }\end{array}$ & Anual & $\begin{array}{l}\text { P7.1 Inventário de } \\
\text { emissões de gases efeito } \\
\text { estufa } \\
\text { P7.2 Estratégia } \\
\text { corporativa de baixo } \\
\text { carbono }\end{array}$ \\
\hline $\begin{array}{l}7 \text { objetivos } \\
\text { estratégicos }\end{array}$ & 10 indicadores BSC & 6 indicadores GRI & & & & \begin{tabular}{|l|}
\multicolumn{1}{|c|}{14 iniciativas } \\
estratégicas
\end{tabular} \\
\hline
\end{tabular}


Indicadores estratégicos para o BSC à luz da GRI (cont.)

\begin{tabular}{|c|c|c|c|c|c|c|}
\hline \multirow[b]{3}{*}{ 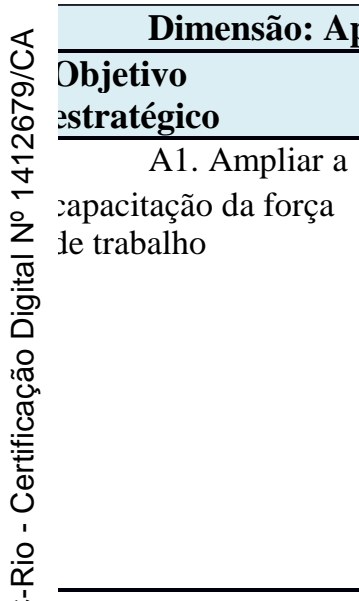 } & \multirow[b]{2}{*}{ Indicador BSC } & \multirow{2}{*}{$\frac{\text { ento }}{\text { Indicador GRI }}$} & \multirow[b]{2}{*}{ Métrica } & \multirow[b]{2}{*}{ Linha de base (2013) e Metas } & \multirow[b]{2}{*}{ Frequência } & \multirow[b]{2}{*}{$\begin{array}{l}\text { Iniciativas } \\
\text { estratégicas }\end{array}$} \\
\hline & & & & & & \\
\hline & \begin{tabular}{l}
\multicolumn{1}{c}{ IA1 - } \\
Investimento em \\
capacitação da \\
força de trabalho
\end{tabular} & \begin{tabular}{l}
\multicolumn{1}{c}{ LA10 - } \\
Média de horas de \\
treinamento \\
$\quad$ HR 3 - \\
Capacitação em \\
Direitos Humanos
\end{tabular} & $\begin{array}{l}\text { IA1: Indicador composto: } \\
\text { Média de horas de } \\
\text { treinamento da força de } \\
\text { trabalho/planejado/ano } \\
\quad \text { Valor investido em } \\
\text { capacitação da força de } \\
\text { trabalho/planejado/ano } \\
\text { Média de horas de } \\
\text { Capacitação da força de trabalho } \\
\text { em Direitos Humanos } \\
\text { /planejado/ano }\end{array}$ & $\begin{array}{l}\text { Mínimo de } 75 \% \text { de } \\
\text { projetos de capacitação da força } \\
\text { de trabalho } \\
\text { realizados/planejados/ano } \\
\text { Capacitação de } 100 \% \text { dos } \\
\text { funcionários da área de } \\
\text { atendimento/ano até } 31.12 .2015\end{array}$ & Anual & $\begin{array}{l}\text { A1.1 } \\
\begin{array}{l}\text { Capacitação da } \\
\text { de trabalho }\end{array}\end{array}$ \\
\hline $\begin{array}{l}\text { ن } \quad \text { A2. Fortalecer } \\
\stackrel{2}{2} \text { zompetências } \\
\text { estratégicas }\end{array}$ & \begin{tabular}{l}
$\quad$ IA2 \\
Investimento em \\
fortalecimento das \\
competências \\
estratégicas \\
$\quad$ Nota: Avaliar \\
possível inclusão de \\
ES1. Número de \\
funcionários com PhD \\
em áreas relevantes \\
\multicolumn{2}{c}{ ES9. } \\
Intercâmbios.
\end{tabular} & $\begin{array}{l}\text { LA10 - } \\
\text { Média de horas de } \\
\text { treinamento } \\
\text { LA12 - } \\
\text { Análise de } \\
\text { desempenho e } \\
\text { desenvolvimento } \\
\text { de carreira }\end{array}$ & $\begin{array}{l}\text { IA2: Indicador composto: } \\
\text { Média de horas de } \\
\text { capacitação das competências } \\
\text { estratégicas/planejado/ano } \\
\text { Valor investido em } \\
\text { capacitação das competências } \\
\text { estratégicas/planejado/ano } \\
\text { Número de participações } \\
\text { em congressos/participações } \\
\text { planejadas /ano (com } \\
\text { apresentação de trabalhos) } \\
\text { Número de intercâmbios } \\
\text { com instituições congêneres por } \\
\text { período. }\end{array}$ & $\begin{array}{l}\text { Mínimo de } 75 \% \text { dos } \\
\text { projetos de capacitação de } \\
\text { competências estratégicas } \\
\text { realizados/planejados/ano } \\
\quad \text { Realização de } 2 \\
\text { doutorados e } 3 \text { mestrados até } \\
\text { 31.12.2016. } \\
\quad 100 \% \text { de participações em } \\
\text { congressos/participações } \\
\text { planejadas /ano (com } \\
\text { apresentação de trabalhos) } \\
\quad \text { Realização de pelo menos } \\
1 \text { intercâmbio com instituições } \\
\text { congêneres por ano. }\end{array}$ & Anual & $\begin{array}{l}\quad \text { A2.1 } \\
\text { Fortalecimento das } \\
\text { competências } \\
\text { estratégicas }\end{array}$ \\
\hline \begin{tabular}{l}
\multicolumn{1}{c}{ A3. } \\
Desenvolver um \\
programa de gestão \\
da informação e do \\
conhecimento
\end{tabular} & $\begin{array}{l}\quad \text { IA3 - Grau } \\
\text { de maturidade da } \\
\text { gestão da } \\
\text { informação e do } \\
\text { conhecimento }\end{array}$ & $\begin{array}{ll}\text { Não } & \text { se } \\
\text { aplica } & \end{array}$ & $\begin{array}{l}\quad \text { IA3: Plano de ação para } \\
\text { gestão da informação e do } \\
\text { conhecimento realizado/planejado }\end{array}$ & $\begin{array}{l}\text { Linha de base (2013) e } \\
\text { metas para curto, médio e longo } \\
\text { prazos }\end{array}$ & Anual & $\begin{array}{l}\text { A3.1 Gestão do } \\
\text { Conhecimento da } \\
\text { FPCRJ }\end{array}$ \\
\hline
\end{tabular}


Indicadores estratégicos para o BSC à luz da GRI (cont.)

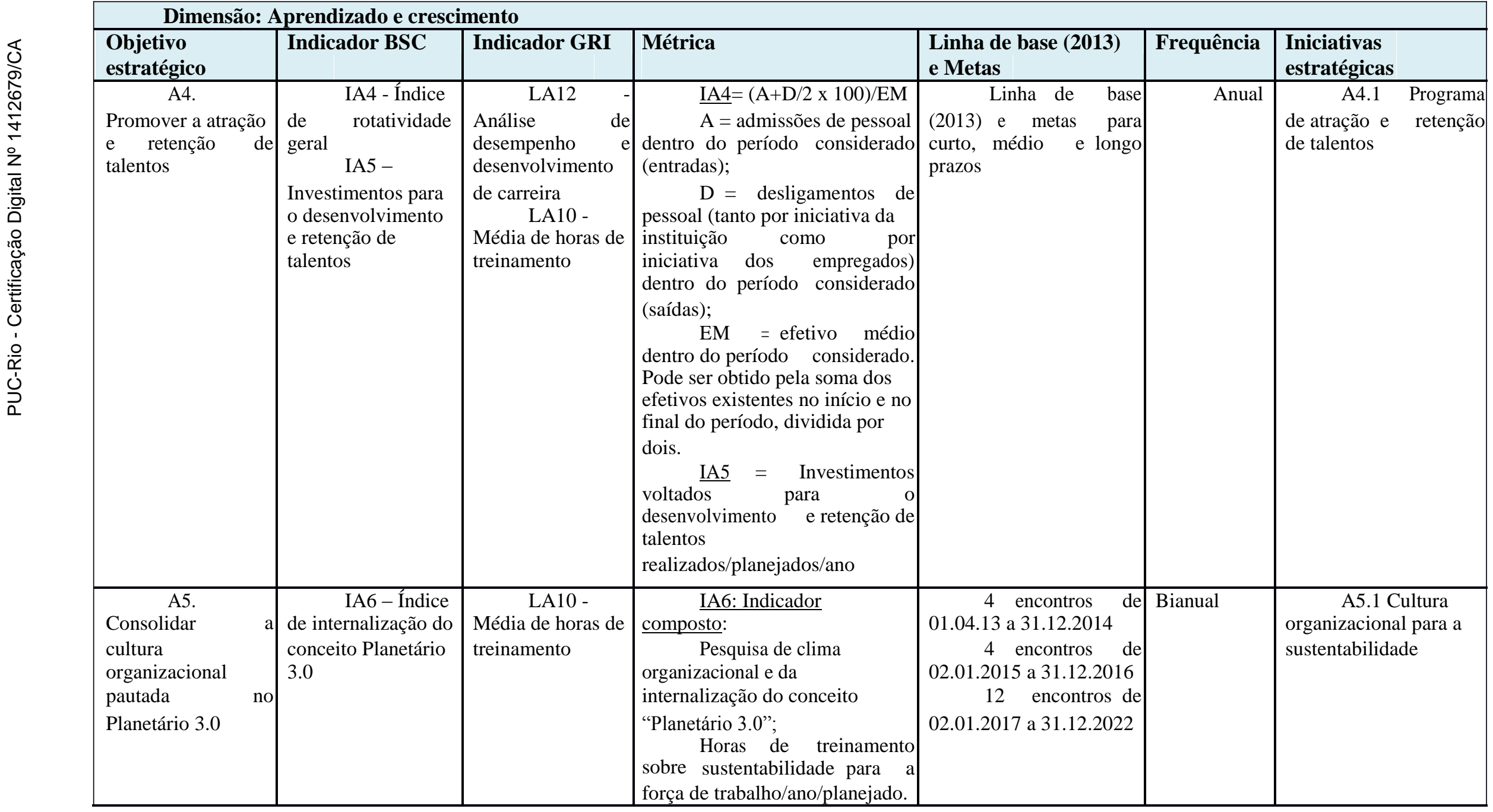


Indicadores estratégicos para o BSC à luz da GRI (cont.)

\begin{tabular}{|c|c|c|c|c|c|c|}
\hline \multicolumn{7}{|c|}{ Dimensão: Aprendizado e crescimento } \\
\hline $\begin{array}{l}\text { Objetivo } \\
\text { estratégico }\end{array}$ & Indicador BSC & Indicador GRI & Métrica & $\begin{array}{l}\text { Linha de base (2013) e } \\
\text { Metas }\end{array}$ & Frequência & $\begin{array}{l}\text { Iniciativas } \\
\text { estratégicas }\end{array}$ \\
\hline \multirow[t]{3}{*}{\begin{tabular}{l}
\multicolumn{1}{c}{ A6. } \\
Disponibilizar \\
ambiente físico e \\
infraestrutura com \\
segurança e \\
acessibilidade
\end{tabular}} & \multirow{3}{*}{\begin{tabular}{l}
\multicolumn{1}{c}{ IA7 - Grau } \\
de segurança e \\
acessibilidade \\
\multicolumn{1}{c}{ IA8 - Índice } \\
de reclamações \\
referentes a \\
problemas de \\
infraestrutura
\end{tabular}} & \multirow{3}{*}{\begin{tabular}{l}
\multicolumn{1}{c}{ EC8 - } \\
Infraestrutura \\
com benefícios \\
públicos \\
\multicolumn{1}{c}{ LA8 - } \\
Programas de \\
educaçao, \\
treinamento, \\
aconselhamento, \\
prevenção e \\
controle de risco \\
para empregados \\
$\quad$ LA7 - \\
Taxas de lesões, \\
doenças \\
ocupacionais, dias \\
perdidos, \\
absenteísmo e \\
óbitos
\end{tabular}} & \begin{tabular}{ll}
\multicolumn{1}{c}{ IA7: } & Indicador \\
composto & \multicolumn{2}{c}{ Segurança: taxas } \\
lesões e acidentes de \\
empregados e visitantes/ano
\end{tabular} & \multirow[t]{3}{*}{$\begin{array}{l}\text { Linha de base (2013) e } \\
\text { metas para curto, médio e } \\
\text { longo prazos }\end{array}$} & \multirow[t]{3}{*}{ Anual } & \multirow{3}{*}{\begin{tabular}{l}
\multicolumn{1}{c}{ A6.1 } \\
Compatibilização do \\
ambiente físico com as \\
necessidades \\
estruturais \\
$\quad$ A6.2 \\
$\begin{array}{l}\text { Acessibilidade } \\
\text { Segurança }\end{array}$
\end{tabular}} \\
\hline & & & $\begin{array}{l}\text { Acessibilidade: número } \\
\text { de visitantes } \\
\text { portadores de } \\
\text { necessidades especiais/ano/ } \\
\text { número total de visitantes/ano }\end{array}$ & & & \\
\hline & & & $\begin{array}{llr}\text { IA8: } & \text { Número de } \\
\text { reclamações } & \text { referentes a } \\
\text { problemas de } & \text { infraestrutura } \\
\text { recebidas/ano } & \end{array}$ & & & \\
\hline $\begin{array}{l}\text { 6 objetivos } \\
\text { estratégicos }\end{array}$ & $\begin{array}{c}\mathbf{8} \\
\text { indicadores }\end{array}$ & \begin{tabular}{l}
\multicolumn{1}{c}{4} \\
indicadores GRI \\
novos (LA7; \\
LA8; LA10; \\
LA12)
\end{tabular} & & & & \begin{tabular}{|l}
\multicolumn{1}{c}{7 iniciativas } \\
estratégicas
\end{tabular} \\
\hline
\end{tabular}


Quadro 5.4 - Síntese da proposição de indicadores estratégicos para o BSC à luz da GRI

\begin{tabular}{|c|c|c|c|c|}
\hline Dimensão BSC & \begin{tabular}{|l|} 
Objetivos \\
estratégicos
\end{tabular} & $\begin{array}{l}\text { Indicadores } \\
\text { BSC }\end{array}$ & Indicadores GRI* & Iniciativas estratégicas \\
\hline Sustentabilidade & 3 & 3 & 10 & 0 \\
\hline Clientes & 4 & 10 & +2 & 12 \\
\hline Processos internos & 7 & 10 & +2 & 14 \\
\hline $\begin{array}{l}\text { Aprendizado e } \\
\text { crescimento }\end{array}$ & 6 & 8 & +4 & 7 \\
\hline Total & 20 & 31 & 18 & 33 \\
\hline
\end{tabular}

Fonte: Elaborado pelo autor.

Quadro 5.5 - Indicadores GRI incluídos no BSC da FPCRJ

\begin{tabular}{|c|c|c|}
\hline Dimensão GRI & Indicadores GRI & $\mathbf{N}^{\mathbf{0}}$ \\
\hline Econômica & EC1; EC4; EC6; EC8; EC9 & 5 \\
\hline Ambiental & $\begin{array}{l}\text { EN3, EN4, EN5; EN6; EN7; EN8; } \\
\text { EN10; EN16; EN17;EN18; EN22 }\end{array}$ & 11 \\
\hline Social & $\begin{array}{l}\text { SO1; PR5; LA1; LA2; LA7; LA8; } \\
\text { LA10; LA12; HR3 }\end{array}$ & 9 \\
\hline Total & $\begin{array}{l}\text { Dos 25 indicadores BSC, 6 EN } \\
\text { nao estarao na edicao ano base 2012 do } \\
\text { GRI }\end{array}$ & $\mathbf{2 5}$ \\
\hline GRI & & $\mathbf{2 3}$ \\
\hline
\end{tabular}

Fonte: Elaborado pelo autor.

Legenda: Econômicos: EC1 - Valor econômico direto gerado; EC4 - Ajuda financeira do governo; EC6 - gastos com fornecedores locais; EC8 - investimentos em infraestrutura e serviços com benefícios públicos; EC9 - impactos econômicos indiretos

Ambientais: EN5 - Energia economizada em razão de melhorias em conservação; EN6 - Iniciativas para fornecer produtos e serviços com baixo consumo de energia; EN10 - Percentual e volume total de água reciclada e reutilizada; EN16 - emissões diretas e indiretas de GEE; EN17 - Outras emissões indiretas relevantes de GEE;EN18 - Iniciativas para reduzir as emissões de GEE e reduções obtidas; EN22 - Peso total de resíduos, por tipo e método de disposição.

Sociais: SO1 - Programas e práticas para avaliar e gerir os impactos das operações nas comunidades; PR5 - Práticas relacionadas com a satisfação do cliente; LA7 - Taxas de lesões, doenças ocupacionais, dias perdidos, absenteísmo e óbitos; LA8- Programas de educação, treinamento, aconselhamento, prevenção e controle de risco para empregados etc.; LA10 - Média de horas de treinamento; LA12- Análise de desempenho e desenvolvimento de carreira. 


\section{6.}

\section{Ficha de indicadores}

Abaixo apresenta-se o modelo da ficha de indicadores utilizada neste estudo de caso para melhor entendimento dos resultados.

Quadro 5.6 - Ficha de indicadores

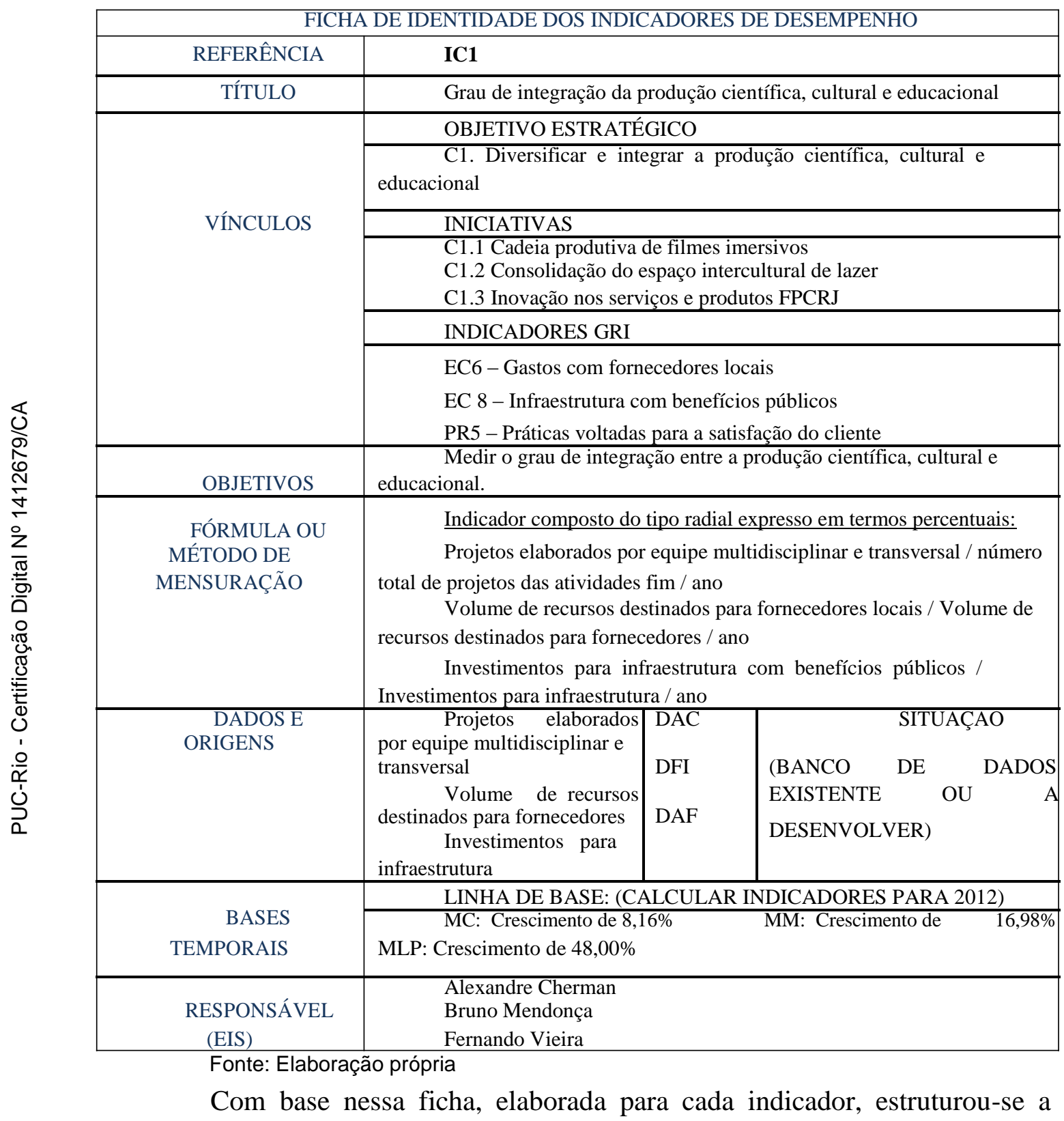

coleta de dados e evidenciou-se os responsáveis institucionais por cada informação relevante para a elaboração do mapa, bem como os métodos de mensuração, tornando a informação transparente e de fácil entendimento. 


\section{7.}

\section{Considerações finais do capítulo}

Com relação às dimensões da sustentabilidade (econômica, ambiental e social), nenhum novo aspecto foi apontado para ser incluído nos Conjuntos de Indicadores, fazendo com que permanecessem os aspectos originalmente descritos pela GRI, o que mostra consonância com o perfil de atividade dos CDCEC.

De um total de 103 (cento e três) indicadores da GRI, 25 (vinte e cinco) indicadores foram inseridos no modelo, abrangendo todas as dimensões e aspectos propostos pelo guia. Inseriu-se também um total de 8 (oito) novos indicadores, não abordados pelo GRI, por se tratar de aspectos peculiares do tipo de instituição e contexto local.

Verificou-se que este modelo atende as premissas do GRI bem como sugere ser capaz de avaliar o desempenho sustentável de CDCEC, permitindo que, a partir de uma visão holística destas organizações, os gestores possam direcionar suas estratégias para a sustentabilidade e motivas outros centros congêneres à perseguir o mesmo, auxiliando os centros urbanos onde estes CDCEC estão inseridos, a alcançar as diretrizes e objetivos de desenvolvimento sustentável. 


\section{6 \\ Conclusões e recomendações}

Os indicadores e métricas de desempenho em sustentabilidade expostos neste estudo foi desenvolvido e implementado por um centro de difusão de ciência, educação e cultura (CDCEC) no município do Rio de Janeiro, mais especificamente pela Fundação Planetário da Cidade do Rio de Janeiro. Todo o processo envolveu cerca de sessenta colaboradores das diversas áreas da FPCRJ, incluindo as unidades da Gávea e de Santa Cruz, bem como vários representantes de partes interessadas externas, que contribuíram a partir de opiniões coletadas em entrevistas semi-estruturadas.

A partir de 2013, tanto o modelo de gestão, pautado nos três pilares da sustentabilidade, quanto o Plano Estratégico da FPCRJ (2013-2022) foram disseminados junto aos representantes de todas as partes interessadas internas e externas, através de reuniões e seminários especiais.

Acredita-se que o modelo de gestão sustentável da Fundação Planetário da Cidade do Rio de Janeiro, aqui descrito, com base nos instrumentos de medição de desempenho propostos por este estudo, embora tenha sido resultante de um projeto de estudo de caso exclusivo da FPCRJ, possa ser replicado por outras instituições congêneres, pois o mesmo foi concebido com esta finalidade e também por adotar referenciais normativos consagrados como as diretrizes GRI para definir seu sistema de indicadores-chaves.

O objetivo geral deste trabalho, propor indicadores e métricas para a gestão sustentável de Centros de Difusão de Ciência, Educação e Cultura, tomando-se como espaço de aplicação a Fundação Planetário da Cidade do Rio de Janeiro, foi alcançado, conforme demonstra o quadro 5.3 (cap.5), onde se sugere um conjunto de 31 indicadores-chave.

Para caracterizar centros de difusão de ciência, educação e cultura, buscando identificar requisitos de qualidade de serviços prestados por esse tipo de instituição e indicadores de desempenho-chave, fez-se um breve relato de casos internacionais e buscou-se na literatura especializada, dados que substanciassem 
as boas práticas encontradas, identificando e analisando referenciais normativos de sustentabilidade, tendo em vista a escolha de indicadores e métricas aplicáveis a Centros de Difusão de Ciência, Educação e Cultura.

Dentre tais referenciais, percebeu-se que o GRI apresenta-se como um modelo mais aproximado das necessidades específicas de CDCEC, no entanto, constatou-se a necessidade de inclusão de alguns novos indicadores e métricas de desempenho sustentável, visando uma maior abrangência.

No caso específico da FPCRJ, evidenciou-se a necessidade de se adaptar a ferramenta de gestão estratégica Balanced Scorecard para a efetiva elaboração de seu PE 2013-2022, tendo em vista que a dimensão "mercado", originalmente proposta pela ferramenta, não traduziria a realidade de centros de difusão de ciência, educação e cultura que desejam atuar de modo sustentável, considerandose os preceitos de uma gestão pública moderna focada em resultados e orientada para o cidadão.

Como resultado conclui-se ser possível incentivar outros Planetários e CDCEC no Brasil e no mundo a incorporarem a sustentabilidade em seus modelos de gestão, como ilustrado pelo caso da FPCRJ, sendo estabelecido padrões de comparação e, endereçam-se algumas recomendações a tais organizações:

- Uma consulta sistemática às diversas partes interessadas dos CDCEC deveria ser realizada por esses Centros, para que pudessem definir assertivamente suas proposições de valor em seus modelos de negócio; perceber melhor o que deve ser medido e monitorado através de indicadores de sustentabilidade; e priorizar atividades relacionadas à sustentabilidade a serem implementadas no curto, médio e longo prazos.

- Em conjunto com uma revisão profunda das políticas governamentais e legislação vigente, esse tipo de consulta sistemática poderia ser útil não somente para a revisão dos indicadores atuais e planos de ação, mas, sobretudo, para ser usada como ferramenta para se obter consenso sobre as questões de sustentabilidade entre CDCEC e Planetários de uma determinada região ou país.

- Monitoramento de políticas locais, regionais ou nacionais de incentivo a práticas de sustentabilidade em todos CDCEC, 
- incluindo Planetários. Isso contribuiria para o desenvolvimento de planos de ação e iniciativas voltadas para a sustentabilidade a serem implementadas por esses centros, em resposta a políticas e mecanismos locais, regionais ou nacionais.

- Deve ser estabelecido um conjunto de parâmetros de referência ou metas de sustentabilidade para Planetários como benchmarking para orientar essas instituições sobre como tornar suas práticas atuais de gestão mais sustentáveis. Em nível internacional, como sugestão, essa iniciativa poderia ser coordenada pela International Planetarium Society (IPS).

- Melhoria permanente dos métodos e práticas de gestão pautadas nos pilares da sustentabilidade e divulgação de 'boas práticas' de sustentabilidade de Planetários e CDCEC através de reuniões periódicas organizadas para este fim (encontros locais, nacionais ou reuniões internacionais).

- Desenvolvimento de um programa de reconhecimento das ações de sustentabilidade promovidas pelos órgãos competentes a fim de ranquear as instituições congêneres e premiá-las por tais ações.

A partir desta pesquisa, sugere-se ainda a construção coletiva de orientações específicas para CDCEC, com base na experiência da FPCRJ e outras instituições congêneres, na perspectiva de encaminhamento à Global Reporting Initiative. Para outros setores da economia, por inciativa de seus representantes, foram definidas diretrizes específicas com base em suas melhores práticas de sustentabilidade, que passaram a constar das orientações setoriais da GRI em sua página na web, no entanto, não existem ainda tais diretrizes para CDCEC. 


\section{Referências bibliográficas}

Adams, E. Towards sustainability indicators for museums in Australia. BSc (Hons). The University of Adelaide. Australia, 2010.

Alcaraz, C.; Hume, M.; Sullivan, M.G. Creating sustainable practice in a museum context: adopting service-centricity in non-profit museums. Australasian Marketing Journal, v.17, n.4, p.219-225, 2009.

Andoniadis, A. Museum retailing: a handbook of strategies for success. New York: MuseumsEtc, 2010.

Ashley, P. A. et al. Ética e responsabilidade social nos negócios. São Paulo: Saraiva, 2002.

Associação Brasileira de Normas Técnicas. ABNT. NBR ISO 14065/2012: Gases do efeito estufa: requisitos para organismos de validação e verificação de gases de efeito estufa para uso em acreditação e outras formas de reconhecimento. Rio de Janeiro: ABNT, 2012.

Associação Brasileira de Normas Técnicas. ABNT. NBR ISO 26000/2010: Diretrizes sobre responsabilidade social. Rio de Janeiro: ABNT, 2010.

Bagdali, S.; Polino, C. Institutional change in Italian museums: does the museum director have a role to play?. International Journal of Arts Management, v.8, n.3, p.4-18, 2006.

Bieker, T. et al. Towards a sustainability balanced scorecard linking environmental and social sustainability to business strategy. In: Proceedings of the 2001 Business Strategy and the Environment Conference, pp. 1-15, U.K.: Leeds. 2001.

Blagoeva-Yarkova, Y. The role of local cultural institutions for local sustainable development. the case-study of Bulgaria, Trakia Journal of Sciences, v.10, n.4, p.42-52, 2012.

Bossel, H. Earth at a crossroads paths to a sustainable future. Cambridge University Press, Cambridge, UK. v.6. 1998.

Bossel, H. Indicators for sustainable development: theory, method, applications; a report to the Balaton Group. International Institute for Sustainable Development, Winnipeg, Manitoba, Canada, 1999. Disponivel em: <http://iisd.ca/about/prodcat/perfrep.htm\#balaton > Acesso em: 09 de março 2016 
Bowen, S. A., Expansion of Ethics as the Tenth Generic Principle of Public Relations Excellence: A Kantian Theory and Model for Managing Ethical Issues. Journal of Public Relations Research. v.16 n.1. p.65-92, 2004.

Brasil. Ministério do Planejamento, Orçamento e Gestão. Secretaria de Planejamento e Investimentos Estratégicos. SPI. Indicadores de programas: guia metodológico. Brasília: MP, 2010.

Brasil. Ministério do Planejamento, Orçamento e Gestão. Secretaria de Gestão. Melhoria da gestão pública por meio da definição de um guia referencial para medição do desempenho da gestão, e controle para o gerenciamento dos indicadores de eficiência, eficácia e de resultados do Programa Nacional de Gestão Pública e Desburocratização. Produto 1: Mapeamento bibliográfico e do estado da arte sobre indicadores de gestão. Brasília: MP, 2009.

Brignall, T. J. S. The unbalanced scorecard: a social and environmental critique. In: Performance Measurement and Management: research and action. Boston: Performance Measurement Association, 2002.

Brown, H. S.; De Jong, M.; Lessindrenska, T. The rise of the Global Reporting Initiative (GRI) as a case of institutional entrepreneurship. Corporate Social Responsibility Initiative, Working Paper $\mathrm{n}^{\mathrm{o}}$ 36. Cambridge, MA: John F. Kennedy School of Government, Harvard University, 2007.

Brundtland, G. H. (Org.) nosso futuro comum. Rio de Janeiro: FGV, 1987.

Cabral-Cardoso, C., Ética e responsabilidade social. Comportamento organizacional e gestão. 21 temas e debates para o século XXI. Lisboa, 2002.

Carroll, A. Corporate social responsibility: evolution of a definitional construct. Business \& Society, v. 38, n. 3, p. 268-295, 1999.

Carroll, A. The pyramid of corporate social responsibility: toward the moral management of organizational stakeholders. Business Horizons, v.34, n.4, p.3948, 1991.

Cassiolato, M.; Gueresi, S. Como elaborar modelo lógico: roteiro para formular programas e organizar avaliação. Brasília: IPEA, 2010.

Chitima, S.S. Developing sustainable museums through "greening": a case study of the Zimbabwe Military Museum. In: African Museums in the Making: Reflections on the Politics of Material and Public Culture in Zimbabwe; Mawere, M., Chiwaura, H., Thondhlana, T.P., Eds.; Langaa RPCIG: Bamenda, Camerun, 2015; pp. 223-245.

Corbos R.A., Popescu R.I. The role of festivals and cultural events in the strategic development of cities. Recommendations for urban areas in Romania. Informatica Economica v.16 n.4, p.19-28, 2012. 
Coombs, P. H. Educational challenges in the age of science and technology - In: Popularization of Science and Techonology - Unesco, 1989.

Dahlsrud, A. How corporate social responsibility is defined: an analysis of 37 definitions. Corporate Social Responsibility and Environmental Management, v.15, n.1, p.1-5, 2008.

Deslandes, S. F. A construção do projeto de pesquisa. 2.ed. Petrópolis: Vozes, 1994.

DIB, C. Z. - Formal, non-formal and informal education: concepts/applicability in "Cooperative networks in physics education: conference proceedings 173" American Institute of Physics - New York, 1988.

Drucker, P. O melhor de Peter Drucker: a administração. São Paulo: Nobel, 2002

Duarte, R. Pesquisa qualitativa: reflexões sobre o trabalho de campo. Caderno de Pesquisa, n. 115, p. 139-154, março. 2002.

Eden, C. E.; Huxham, C. Pesquisa-ação no estudo das organizações. In: Handbook de estudos organizacionais: reflexões e novas direções. v. 2. São Paulo: Atlas, 2001.

Elkington, J. Cannibals with forks: Triple bottom line of 21st century business. London: Capstone Publishing Ltd, 1998.

Epstein, M. J.; Manzoni, J.-F. Implementing corporate strategy: from tableau de bord to balanced scorecard. European Management Journal, v. 16, n. 2, p. 190203, 1998.

Ferreira, H.; Cassiolato, M.; Gonzalez, R. Como elaborar modelo lógico de programas: um roteiro básico. Nota Técnica. Brasília: IPEA, 2007.

Ferreira, H; Cassiolato, M; Gonzalez, R. Uma experiência de desenvolvimento metodológico para avaliação de programas: o modelo lógico do Programa Segundo Tempo, Brasília: Ipea, 2009.

Figge, F. et al. The sustainability balanced scorecard. Linking sustainability management to business strategy. Business Strategy and the Environment, v.11, n.5, p. 269-284, 2002.

Fracalanza, H. O que sabemos sobre os livros didáticos para o ensino de ciências no Brasil . UNICAMP, Campinas, 1993.

Friend, J. K.; Jessop, W. N. Local government and strategic choice: an operational research approach to the processes of public planning. London, Tavistok publications. 2. ed. 1969. 
Gallopin, G. C. Environmental and sustainability indicators and the concept of situational indicators. A system approach. Environmental Modelling \& Assessment, v.1, p.101-117, 1996.

Gil, Antonio Carlos. Métodos e técnicas de pesquisa social. São Paulo: Atlas, 1999.

Gilmore, A.; Rentschler, R. Changes in museum management. A custodial or marketing emphasis? Journal of Management Development, v.21, n.10, p. 745$760,2002$.

Global Reporting Initiative. GRI. G4 Sustainability Reporting Guidelines. Amsterdam: GRI, 2014.

Gorgens M., Kusek J.Z. Making monitoring and evaluation systems work: a capacity development toolkit, World Bank publication. 2009.

Gouveia, M.S.F. Cursos de ciências para professores de primeiro grau: elementos para uma política de formação continuada. Campinas 1992 290p. Tese (Doutorado) -- Faculdade de Educação da UNICAMP.

Green Research. Commission of the European Community - Green Paper 'The European Research Area: New Perspectives' 2009. Disponível em: $<$ https://ec.europa.eu/research/era/pdf/era_swp_final.pdf $>$. Acesso em: 09 de janeiro de 2016.

Guimarães, R. P. Aterrizando una Cometa: indicadores territoriales de sustentabilidad. Santiago do Chile: CEPAL/ILPES, 1998. (Serie Investigación, Documento 18/98, LC/IP/G.120).

Hammond, A. et al. Environmental Indicators: a systematic approach to measuring and reporting on environmental policy performance in the context of sustainable development. Washington: WRI, 1995.

Hardi, P. Zdan, T. (eds.). Assessing sustainable development: principles in practice. International Institute for Sustainable Development, Canada: 1997.

Holtz, G. P.; Mota, J. A. Protocolo de quioto: o potencial de sequestro de carbono pela agricultura conservacionista no Brasil. 2005. Disponível em <http://www.fcmc.es.gov.br/download/ArtigoProtocolodeQuiotoFinal.pdf> Acesso 13 de fevereiro de 2016.

Hsiao, C. H.; Yao, M. H. System dynamics approach to visitors' long-term satisfaction with museum: a case study of The National Museum of Natural Science. International Journal of Electronic Business Management, 10 (2), 113121. 2012.

Instituto Ethos de Empresas e Responsabilidade Social. Matriz brasileira de evidências de sustentabilidade. 2004. Disponível em: <http://www.ethos.org.br/sistemas/ifc/>. Acesso em: 13 set. 2015. 
Instituto Ethos de Empresas e Responsabilidade Social. Práticas empresariais de responsabilidade social: relações entre os princípios do Global Compact e os indicadores Ethos de responsabilidade social. São Paulo: Instituto Ethos, 2003. Disponível em: <http://www.ethos.org.br/sistemas/ifc/>. Acesso em: 13 set. 2015.

International Council of Museums. ICOM. Code of ethics for museums. 2013.

Disponível em:

$<$ http://icom.museum/fileadmin/user_upload/pdf/Codes/code_ethics 2013_eng.pdf>. Acesso em: 2 jun. 2015.

Jacobucci, D. F. C. Contribuições dos espaços não formais de educação para a formação da cultura científica. Em extensão, Uberlândia, v.7 n.1 p.36-42, 2008.

Kaplan, R. S.; Norton, D. P. Strategy maps: converting intangible assets into tangible outcomes. Boston, MA: Harvard Business Review Press, 2004.

Kaplan, R. S.; Norton, D. P. Using the balanced scorecard as a strategic management system. Harvard Business Review (Jan./Feb.), p.71-79, 1996.

Kaplan, R.S. The evolution of management accounting. The Accounting Review, v.59, n.3, p. 390-418, 1984.

Kotler, N.G., Kotler, P.; Kotler, W. I. Museum marketing \& strategy, 2nd edition. USA, San Francisco: Jossey-Bass. 2008.

Kotler, P. et al. Marketing 3.0: from products to customers to the human spirit. New York: John Wiley and Sons. 2010.

Lewin, K. Action research and minority problems. Journal of Social Issues, v.2, n.4, p.34-46, 1946.

Maher, J. K.; Clark, J.; Motley, D. G. Measuring museum service quality in relationship to visitor membership: the case of a children's museum. Marketing Management, v.13, n.2, p.29-42, 2011.

Marconi, M. A.; Lakatos, E. M. Fundamentos de metodologia científica. 5. ed. São Paulo: Atlas, 2003.

1.1.1.1.Marković, S.; Jankovic, S.; Komšic, J. Museum service quality measurement using the histoqual model. In: 2nd International Scientific

Conference Tourism in South East Europe 2013. Disponivel em:

<http://papers.ssrn.com/sol3/papers.cfm?abstract_id=2289769>. Acesso em: 2 jun. 2015

Melo Neto, F. Froes, C. Gestão da responsabilidade social corporativa: o caso brasileiro. Rio de Janeiro: Qualitymark, 2001. 
Merriam, S.B. Qualitative research and case study applications in education: revised and expanded from case study research in education. San Francisco: Jossey-Bass Publishers. 1997.

Misiura, S. Heritage marketing. London: Routledge. 2005.

Moldan, B.; Bilharz, S. (Eds.). Sustainability indicators: report of the project on indicators of sustainable development. Chichester: John Wiley \& Sons Ltd., 1997.

Möller, A.; Schaltegger, S. The sustainability balanced scorecard as a framework for eco-efficiency analysis. Journal of Industrial Ecology, v. 9, n.4, p.73-83, 2005.

Montibeller, F. G. O mito do desenvolvimento sustentável: meio ambiente e custos sociais no moderno sistema produtor de mercadorias. UFSC. Florianópolis, 2004.

Oliveira, G. C. G. et al. Visitas guiadas ao Museu Nacional: interações e impressões de estudantes da Educação Básica. Ciência e Educação., v. 20, n. 1, p. 227-242, 2014.

Pettigrew, A. M. Making change in large organizations. London: Sage, 1992.

Pettigrew, A.M. Context and action in the transformation of the firm. Journal of Management Studies, v.24, n.6, p.649-670, 1987.

Pop, I. L.; Sabou, S. Sustainable development of museums in the new context of market economy. Managerial Challenges of the Contemporary Society, v.6, p.3541, 2013.

Pop, I.L.; Borza, A. Sustainable museums for sustainable development. Advances in Business-Related Scientific Research Journal, v. 6, n.2, p.119-131, 2015.

Quiroga-Martínez, R. Los indicadores de sostenibilidad ambiental y de desarrollo sostenible: estado del arte y perspectivas. Comisión Económica para América Latina y el Caribe. Santiago, Chile: CEPAL, 2001.

Radder, L.; Han, X. Perceived quality, visitor satisfaction and conative loyalty in South African heritage museums. International Business \& Economics Research Journal, v. 12, n.10, p.1261-1272, 2013.

Radder, L.; Han, X.; Hou, Y. An integrated evaluation of the heritage museum visit: a disconfirmation approach. International Journal of Management Cases, v.13, n.3, p. 315-326, 2011.

Sink, D. S. The role of measurement in achieving world class quality and productivity management. Industrial Engineering, v.6. p. 23-28, 1991. 
Social Accountability International. SAI. Promoting the human rights of workers around the world. 2001. Disponível em: <http://www.saintl.org/index.cfm?\&stopRedirect=1>. Acesso em: 04 de dezembro de 2015.

Sustainability. Buried treasure: uncovering the business case for corporate sustainability. 2001.Disponível em: 〈http:// www.sustainability.co.uk>. Acesso em: 21 mar. 2015.

Sustainability. Developing value: the business case for sustainability in emerging markets. 2002. Disponível em: <http://www.sustainability.com/developingvalue>. Acesso em: 21 mar. 2015.

Thiollent, M. Metodologia da pesquisa-ação. 15. ed. São Paulo: Cortez, 2007.

Triviños, A. N. S. Introdução à pesquisa em ciências sociais: a pesquisa qualitativa em educação. São Paulo, Atlas, 1987. 175p.

Tunstall, D. Development and using indicators of sustainability in Africa: an overview. Prepared for the Network for Environment and Sustainable Development in Africa (NESDA). Thematic Workshop on Indicators of Sustainable Development, Banjul, The Gambia, May 16-18, 1994.

Van Bellen, H. Indicadores de sustentabilidade: uma análise comparativa. Florianópolis, 2002, 235 p. Tese (Doutorado) - Curso de Pós-Graduação em Engenharia de Produção, Centro Tecnológico, Universidade Federal de Santa Catarina.

Van Bellen, H. M. Indicadores de sustentabilidade: uma análise comparativa. Editora FGV: Rio de Janeiro. 2005.

Van Bellen, H. M. Desenvolvimento sustentável: uma descrição das principais ferramentas de avaliação. Revista Ambiente \& Sociedade, v. VII, n.1, 2004.

Vergara, S. C. Projetos e relatórios de pesquisa em administração. 4 ed. São Paulo: Atlas, 2003.

World Business Council For Sustainable Development. WBCSD. Social responsibility: making good business sense. 2000. Disponível em: <http://www.wbcsd.ch/DocRoot/IunSPdIKvmYH5HjbN4XC/csr2000.pdf>. Acesso em: 21 mar. 2015.

Yin. R. K. Estudo de caso: planejamento e métodos. 3 ed. Porto Alegre: Bookman, 2005.

Zadek, S. Balancing performance, ethics and accountability. Journal of Business Ethics, v.17, p.1421-1442, 1998. 


\section{Anexo 1 - Organograma da Fundação Planetário da Cidade do Rio de Janeiro (FPCRJ)}

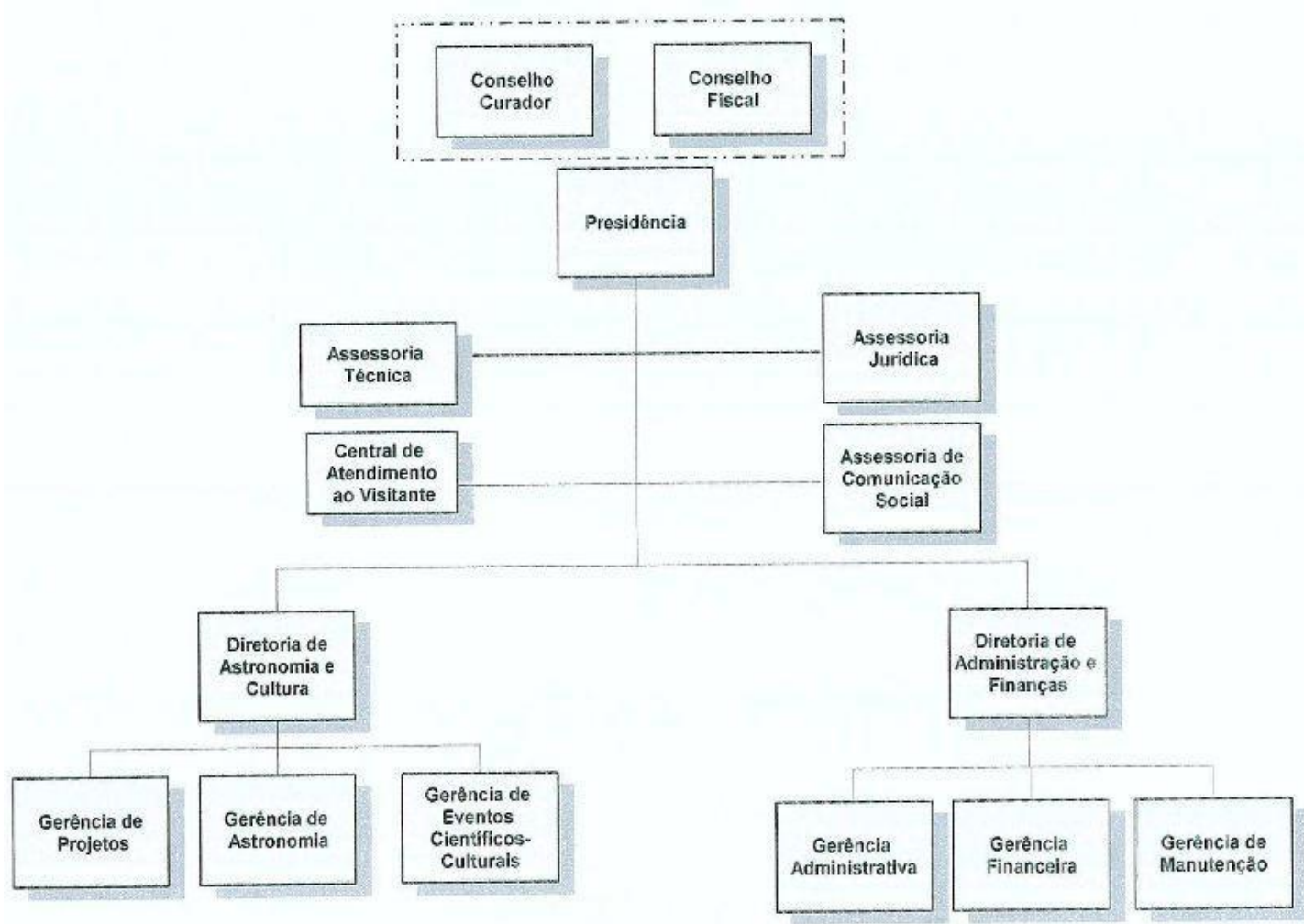

